\title{
Belajar Olah \\ Data dengan \\ EViews
}

Prana Ugiana Gio 


\section{USU Press}

Art Design, Publishing \& Printing

Gedung F, Pusat Sistem Informasi (PSI) Kampus USU Jl. Universitas

No. 9 Medan 20155, Indonesia

Telp. 061-8213737; Fax 061-8213737

usupress.usu.ac.id

(C) USU Press 2015

Hak cipta dilindungi oleh undang-undang; dilarang memperbanyak menyalin, merekam sebagian atau seluruh bagian buku ini dalam bahasa atau bentuk apapun tanpa izin tertulis dari penerbit.

ISBN 9794587907

Perpustakaan Nasional: Katalog Dalam Terbitan (KDT)

Penulis

Belajar Olah Data dengan Eviews / Prana Ugiana Gio --Medan:

USU Press 2015.

v, 62 p. ; ilus.: $24 \mathrm{~cm}$

Bibliografi

ISBN: 979-458-790-7

Dicetak di Medan, Indonesia 


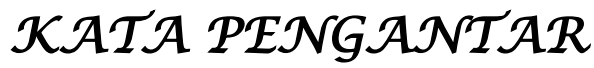

Ahamdulillah, puji syukur atas kehadirat Allah SWT, karena atas izin-Nya, penulis dapat terus mempertahankan semangat untuk menulis, dan akhirnya dapat menyelesaikan buku ini. Hadirnya buku ini, tidak semata-mata atas usaha penulis sendiri, melainkan atas izin-Nya. Sungguh suatu kebahagiaan bagi penulis bisa berbagi sebagian kecil ilmu pengetahuan milik-Nya melalui buku yang berjudul "Belajar Olah Data dengan EViews".

Dalam buku ini, membahas secara ringkas teori-teori mengenai regresi linear berganda dan regresi data panel, serta diberikan langkah-langkah dalam menggunakan software EViews 7. Dengan hadirnya buku ini semoga mempermudah bagi mahasiswa yang sedang menyelesaikan tugas akhir, skripsi, tesis, atau disertasi, yang mensyaratkan penggunaan software EViews dalam pengolahan data, yang mana menggunakan regresi linear berganda atau regresi data panel.

Ucapan terima kasih penulis sampaikan kepada semua pihak yang telah membantu dalam rangka penyelesaian buku ini. Penulis menyadari bahwa buku ini tentunya masih perlu perbaikan, sehingga penulis mengharapkan kritik dan saran yang membangun dari para pembaca agar buku ini dapat menjadi lebih baik. Kritik dan saran dapat ditujukan ke alamat email gioprana89@gmail.com atau website www.olahdatamedan.com.

Medan, April 2015

Prana Ugiana Gio 


\section{"Jkatlah Jlmu dengan Menuliskannya"}

Ali bin Abi Thalib r.a.

"Tinggalkan Jejakmu dalam Suatu Karya yang Bermanfaat"

> Prana Ugiana Cia 


\section{$\mathcal{D} \mathcal{A} \mathcal{F} \mathcal{T} \mathcal{A}$ ISI}

Kata Pengantar

Daftar Isi

\section{Bab 1. PERNAK PERNIK STATISTIK} 1

Pendekatan Nilai Probabilitas (P-Value) dan Nilai Kritis (Critical Value) dalam Pengambilan Keputusan terhadap Hipotesis 1

Distribusi Populasi (Population Distribution) 3

Distribusi Sampling Rata-Rata Sampel $\overline{\mathrm{x}}$ (Sampling Distribution of $\bar{x}) \quad$.......... 4

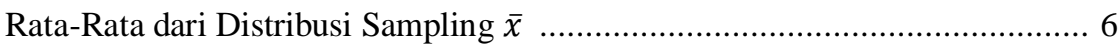

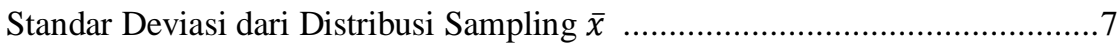

Bentuk Distribusi Sampling dari Rata-Rata $\bar{x}$....................................... 13

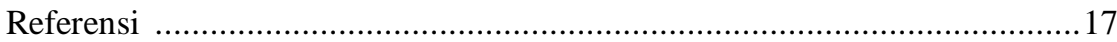

Bab 2. REGRESI LINEAR BERGANDA .......................................18

Sekilas Regresi Linear Berganda ..................................................... 18

Mengukur Kecocokkan Model Regresi Linear Berganda terhadap Data dengan Koefisien Determinasi $\left(r^{2}\right)$.....................................................20

Menguji Signifikansi Kecocokkan Model Regresi Linear Berganda

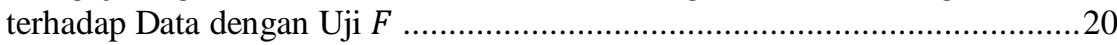

Uji Signifikansi Koefisien Regresi Secara Individu dengan Uji $t$.................22

Contoh Kasus dalam Regresi Linear Berganda .....................................23

Asumsi-Asumsi dalam Regresi Linear Berganda .................................. 26

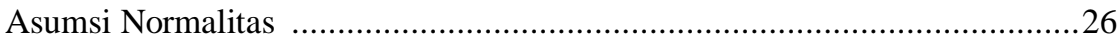

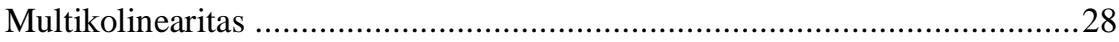


Asumsi Non-Autokorelasi

Asumsi Homoskedastisitas

Penyelesaian Dalam Eviews

Interpretasi Output Eviews

Referensi

Bab 3. REGRESI DATA PANEL .63

Sekilas Mengenai Data Cross-Section, Data Time Series, dan Data Panel.......63

Keuntungan Menggunakan Data Panel .65

Estimasi Model Regresi Data Panel (Pendekatan Fixed Effects) .66

Model Regresi Data Panel dengan Intersep dan Koefisien-Koefisien

Kemiringan Konstan .66

Model Regresi Data Panel dengan Intersep Bervariasi sepanjang Unit Cross-Sectional, namun Koefisien-Koefisien Kemiringan Konstan (Fixed Effects Model)

Estimasi Model Regresi Data Panel (Pendekatan Random Effects (REM))

Pemilihan Model antara FEM (Fixed Effects Model) dan CEM (Common Effects Model)

Pemilihan Model antara FEM (Fixed Effects Model) dan ECM (Error Component Model)

Penyelesaian Dalam Eviews

Referensi .90 


\section{PERNAK PERNIK STATISTIK}

\section{Pendekatan $\mathcal{N} i$ lai Probabilitas (P-Value) dan $\mathcal{N} i$ laí Krítís (Critical Value) dalam Pengambilan Keputusan terhadap Hipotesis}

Penentuan dalam pengambilan keputusan terhadap hipotesis dapat digunakan pendekatan nilai kritis (critical value approach) atau pendekatan nilai probabilitas (probability value approach). Perlu diperhatikan bahwa pendekatan nilai kritis dan pendekatan nilai probabilitas tidak saling berbeda. Mann dan Christopher (2011:391) menyatakan sebagai berikut.

"Note that two approaches-the p-value approach and the critical-value approach-are not mutually exclusive".

Dalam pendekatan nilai probabilitas ( $p$-value), jika nilai probabilitas ( $p$-value) lebih besar atau sama dengan tingkat signifikansi $(\alpha)$, maka hipotesis nol $\left(H_{0}\right)$ diterima. Namun jika nilai probabilitas ( $p$-value) lebih kecil dibandingkan tingkat signifikansi, maka hipotesis nol ditolak. Mann dan Christopher (2011:391) menyatakan sebagai berikut.

"Using p-value approach, we reject the null hypothesis if

$$
\text { p-value }<\alpha \text { or } \alpha>p \text {-value, }
$$

and we do not reject the null hypothesis if

$$
\text { p-value } \geq \alpha \text { or } \alpha \leq \text {-value". }
$$

Untuk uji satu sisi (one-tailed test), nilai probabilitas ( $p$-value) dapat direpresentasikan sebagai luas pada sisi (tail) dari kurva distribusi sampling di luar (beyond) dari nilai statistik sampel (value of statistic sample). Pada Gambar 1.1, nilai probabilitas ( $p$-value) menunjukkan luas pada sisi dari kurva distribusi sampling di sebelah kanan dari nilai rata-rata sampel teramati $(\bar{x})$.

Untuk uji dua sisi (two-tailed test), nilai probabilitas ( $p$-value) dapat direpresentasikan sebagai dua kali luas pada bagian sisi (tail) dari kurva distribusi sampling di luar (beyond) dari nilai statistik sampel (value of statistic sample). Pada Gambar 1.2 menunjukkan nilai probabilitas ( $p$-value) untuk uji dua sisi (two-tailed test). 


\section{Gambar 1.1}

Nilai probabilitas ( $p$ value) untuk uji sisi kanan (right-tailed test).

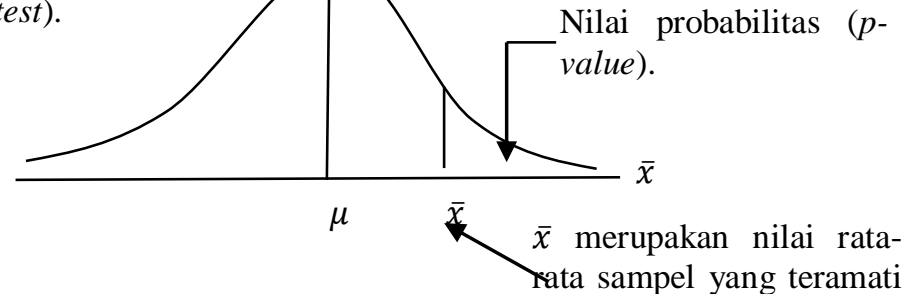

\section{Gambar 1.2}

Jumlah dari dua area menghasilkan p-value.

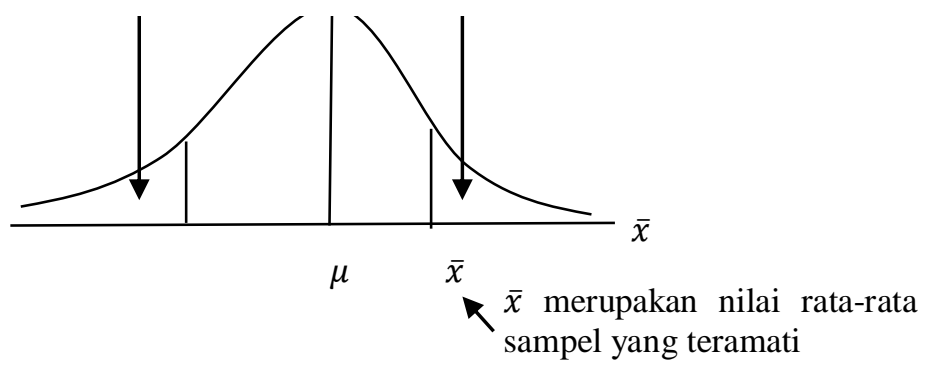

Dalam pendekatan nilai kritis (critical-value approach), nilai tingkat signifikansi $(\alpha)$ ditentukan lebih dahulu sebelum menghitung nilai kritis. Nilai dari tingkat signifikansi dapat direpresentasikan sebagai luas total daerah penolakkan hipotesis nol (Mann dan Christopher, 2011:394). Pada kasus distribusi normal (standar), nilai kritis normal $\left(z_{\text {kritis }}\right)$ dihitung berdasarkan tabel distribusi normal pada suatu tingkat signifikansi tertentu. Selanjutnya menghitung nilai statistik dari uji $z$ atau $z_{\text {hitung }}$ berdasarkan nilai rata-rata sampel $\bar{x}$ yang diamati. Untuk uji dua sisi (two-tailed test), daerah penerimaan dan penolakkan hipotesis nol digambarkan sebagai berikut.

\section{Gambar 1.3}

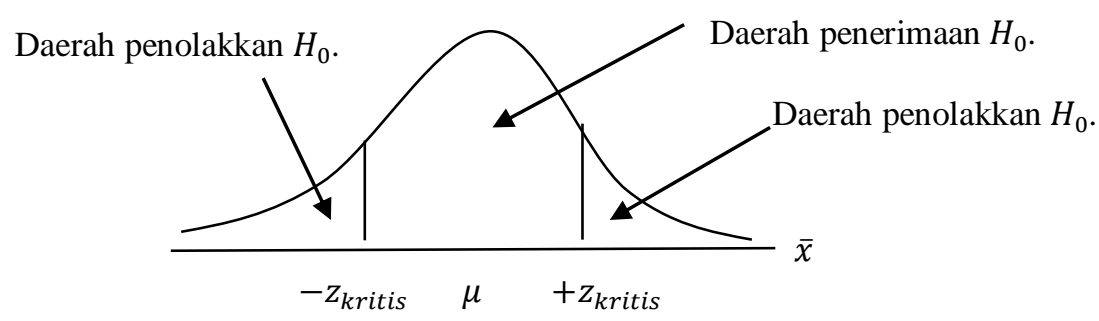


Jika $z_{\text {hitung }}>+z_{\text {kritis }}$, maka hipotesis nol ditolak dan hipotesis alternatif diterima atau jika $z_{\text {hitung }}<-z_{\text {kritis }}$, maka hipotesis nol ditolak dan hipotesis alternatif diterima. Namun jika $-z_{\text {kritis }} \leq z_{\text {hitung }} \leq+z_{\text {kritis }}$, maka hipotesis nol diterima dan hipotesis alternatif ditolak. Atau dapat juga dinyatakan

$$
\begin{aligned}
& \text { Jika }\left|z_{\text {hitung }}\right| \leq\left|z_{\text {kritis }}\right|, \text { maka } H_{0} \text { diterima, } H_{1} \text { ditolak. } \\
& \text { Jika }\left|z_{\text {hitung }}\right|>\left|z_{\text {kritis }}\right|, \text { maka } H_{0} \text { ditolak, } H_{1} \text { diterima. }
\end{aligned}
$$

\section{Distríbusi Populasi (Population Distríbution)}

Distribusi populasi dapat diartikan sebagai distribusi probabilitas dari data populasi. Andaikan dalam suatu kelas hanya terdiri lima mahasiswa jurusan matematika. Berikut disajikan nilai ujian matakuliah kalkulus dari lima mahasiswa tersebut.

$$
70,75,80,80,90
$$

Andaikan $x$ menyatakan nilai ujian matakuliah kalkulus dan $P(x)$ menyatakan probabilitas dari suatu nilai ujian matakuliah kalkulus. Berikut disajikan distribusi probabilitas dari data populasi nilai ujian matakuliah kalkulus (Tabel 1.1).

\section{Tabel 1.1 Distribusi Probabilitas dari Data Populasi Nilai Ujian Kalkulus}

\begin{tabular}{|c|c|}
\hline$x$ & $P(x)$ \\
\hline 70 & 0.2 \\
\hline 75 & 0.2 \\
\hline 80 & 0.4 \\
\hline 90 & 0.2 \\
\hline \multicolumn{2}{|c|}{$\sum P(x)=1$} \\
\hline
\end{tabular}

Nilai rata-rata dan standar deviasi berdasarkan data pada Tabel 1.1 dihitung sebagai berikut.

$$
\begin{gathered}
\mu=\frac{70+75+80+80+90}{5}=79 \\
\sigma=\sqrt{\frac{(70-79)^{2}+(75-79)^{2}+\cdots+(90-79)^{2}}{5}}=6,633 .
\end{gathered}
$$


Perhatikan bahwa $\mu$ dan $\sigma$ merupakan nilai-nilai parameter populasi. Parameter dapat diartikan sebagai suatu nilai atau ukuran yang dihitung berdasarkan populasi.

\section{Distribusi Sampling Rata-Rata Sampel $\overline{\mathbf{x}}$ (Sampling Distribution of $\overrightarrow{\mathbf{x}}$ )}

Berbeda dengan statistik deskriptif yang rangkaian pengerjaannya meliputi mengorganisasi (organizing), menampilkan (displaying), dan menjelaskan data dengan menggunakan tabel, grafik, serta ukuran-ukuran seperti rata-rata, median, serta modus, pada statistik inferensi sampai pada tahap pengambilan keputusan atau prediksi mengenai populasi berdasarkan sampel yang diteliti. Konsep mengenai distribusi sampling memberikan teori yang penting dalam prosedur-prosedur statistik inferensi.

Daniel (2005:129) menyatakan sebagai berikut.

"Sampling distributions serve two purposes: (1) they allow us to answer probability questions about sample statistics, and (2) they provide the necessary theory for making statistical inference procedures valid".

Nilai dari parameter suatu populasi bersifat konstan. Dalam hal ini, untuk setiap data populasi hanya memiliki satu nilai rata-rata populasi $\mu$. Namun hal ini belum tentu berlaku untuk rata-rata sampel $\bar{x}$. Sampel-sampel yang ditarik dari populasi yang sama dan dengan ukuran yang sama dapat menghasilkan nilai rata-rata sampel yang berbeda-beda. Jadi, nilai rata-rata sampel bergantung pada nilai-nilai yang berada dalam sampel tersebut. Oleh karena itu, rata-rata sampel $\bar{x}$ bersifat variabel acak (random variable). Sebagaimana pada variabel acak, maka rata-rata sampel $\bar{x}$ memiliki distribusi probabilitas. Distribusi probabilitas $\bar{x}$ sering disebut dengan istilah distribusi sampling dari $\bar{x}$. Ukuran-ukuran statistik lainnya seperti median, modus, dan standar deviasi juga memiliki distribusi sampling (Mann dan Christopher, 2011:302).

Pada pembahasan sebelumnya mengenai "Distribusi Populasi", diketahui data populasi

$$
70,75,80,80,90 \text {. }
$$

Andaikan masing-masing nilai diberi kode huruf sebagai berikut.

$$
\mathrm{V}=70, \mathrm{~W}=75, \mathrm{X}=80, \mathrm{Y}=80 \text {, dan } \mathrm{Z}=90 .
$$

Maka, V, W, X, Y, dan Z merupakan kode-kode huruf yang menyatakan kelima nilai ujian matakuliah kalkulus. Kemudian misalkan akan diambil sampel yang terdiri tiga nilai tanpa pengembalian (without replacement). Maka banyaknya kemungkinan sampel yang terambil sebagai berikut. 


$$
C_{3}^{5}=\frac{5 !}{(5-3) ! 3 !}=\frac{5.4 .3 .2 .1}{(2.1)(3.2 .1)}=10 \text { kemungkinan sampel }
$$

VWX, VWY, VWZ, VXY, VXZ, VYZ, WXY, WXZ, WYZ, XYZ

Perhatikan bahwa terdapat 10 kemungkinan sampel. Sampel VWX berarti mengandung nilai 70,75 , dan 80 , sampel WYZ berarti mengandung nilai 75 , 80, dan 90, dan seterusnya. Tabel 1.2 menyajikan sampel-sampel yang mungkin terambil beserta penghitungan nilai rata-rata.

Tabel 1.2 Sampel-Sampel yang Mungkin Terambil beserta Nilai Rata-Rata

\begin{tabular}{|c|c|c|c|c|}
\hline Sampel & \multicolumn{3}{|c|}{ Nilai-Nilai dalam Sampel } & $\bar{x}$ \\
\hline VWX & 70 & 75 & 80 & 75 \\
\hline VWY & 70 & 75 & 80 & 75 \\
\hline VWZ & 70 & 75 & 90 & 78.33 \\
\hline VXy & 70 & 80 & 80 & 76.67 \\
\hline VXZ & 70 & 80 & 90 & 80 \\
\hline VYZ & 70 & 80 & 90 & 80 \\
\hline WXY & 75 & 80 & 80 & 78.33 \\
\hline WXZ & 75 & 80 & 90 & 81.67 \\
\hline WYZ & 75 & 80 & 90 & 81.67 \\
\hline XYZ & 80 & 80 & 90 & 83.33 \\
\hline
\end{tabular}

Berdasarkan Tabel 1.2, selanjutnya dibentuk tabel distribusi frekuensi dan frekuensi relatif berdasarkan nilai rata-rata sampel (Tabel 1.3). Tabel 1.4 menyajikan distribusi sampling dari rata-rata sampel $\bar{x}$ berdasarkan data pada Tabel 1.2.

Tabel 1.3 Distribusi Frekuensi dan Frekuensi Relatif Berdasarkan Nilai Rata-Rata Sampel

\begin{tabular}{|c|c|c|}
\hline $\bar{x}$ & $f$ & Frekuensi Relatif \\
\hline 75 & 2 & 0.2 \\
\hline 76.67 & 1 & 0.1 \\
\hline 78.33 & 2 & 0.2 \\
\hline 80 & 2 & 0.2 \\
\hline 81.67 & 2 & 0.2 \\
\hline 83.33 & 1 & 0.1 \\
\hline Jumlah & 10 & 1 \\
\hline
\end{tabular}


Tabel 1.4 Distribusi Sampling dari $\bar{x}$ dengan

Ukuran Sampel sebanyak 3

\begin{tabular}{|c|c|}
\hline $\bar{x}$ & $P(x)$ \\
\hline 75 & 0.2 \\
\hline 76.67 & 0.1 \\
\hline 78.33 & 0.2 \\
\hline 80 & 0.2 \\
\hline 81.67 & 0.2 \\
\hline 83.33 & 0.1 \\
\hline \multicolumn{2}{|c|}{$\sum P(x)=1$} \\
\hline
\end{tabular}

Tabel 1.4 menyajikan distribusi probabilitas dari rata-rata sampel $\bar{x}$. Sebagai contoh probabilitas untuk memperoleh sampel yang memiliki nilai rata-rata 81,67 sebesar 0,2 . Atau dapat dinyatakan

$$
P(\bar{x}=81.67)=0.20 \text {. }
$$

\section{Rata-Rata dari Dístríbusí Sampling $\bar{x}$}

Rata-rata dari distribusi sampling $\bar{x}$ (mean of the sampling distribution of $\bar{x}$ ) atau rata-rata dari $\bar{x}$ dilambangkan dengan $\mu_{\bar{x}}$. Berdasarkan Tabel 1.2, berikut akan dihitung rata-rata dari distribusi sampling $\bar{x}$ serta rata-rata populasinya.

$$
\begin{gathered}
\mu_{\bar{x}}=\frac{75+75+78,33+\cdots+83,33}{10}=79 \\
\mu=\frac{70+75+80+80+90}{5}=79 .
\end{gathered}
$$

Perhatikan bahwa bedasarkan perhitungan diperoleh $\mu_{\bar{x}}=79$ dan $\mu=79$. Mann dan Christopher (2011:307) menyatakan sebagai berikut.

"The mean of the sampling distribution of $\bar{x}$ is always equal to the mean of the population. Thus, $\mu_{\bar{x}}=\mu$ '.

Rata-rata sampel $\bar{x}$ disebut juga sebagai estimator atau penduga terhadap ratarata populasi $\mu$. Suatu statistik dikatakan sebagai estimator tak-bias atau unbiased estimator jika nilai rata-rata dari distribusi sampling statistik tersebut sama dengan nilai parameter tertentu. Perhatikan bahwa statistik rata-rata sampel $\bar{x}$ merupakan estimator tak-bias dari parameter rata-rata populasi $(\mu)$, 
karena nilai rata-rata dari distribusi sampling rata-rata $\bar{x}$ selalu sama dengan rata-rata populasi, yakni

$$
\mu_{\bar{x}}=\mu \text {. }
$$

\section{Standar Deviasi dari Dístríbusi Sampling $\bar{x}$}

Diketahui pada pembahasan sebelumnya bahwa rata-rata dari distribusi sampling rata-rata $\bar{x}$ dilambangkan dengan simbol $\mu_{\bar{x}}$, sedangkan rata-rata populasi dilambangkan dengan simbol $\mu$. Standar deviasi dari distribusi sampling rata-rata $\bar{x}$ dilambangkan dengan simbol $\sigma_{\bar{x}}$, sedangkan standar deviasi populasi dilambangkan dengan simbol $\sigma$. Pada pembahasan sebelumnya diketahui bahwa rata-rata dari distribusi sampling rata-rata $\bar{x}$ sama dengan ratarata populasi $\mu$, yakni

$$
\mu_{\bar{x}}=\mu
$$

Namun pada standar deviasi dari distribusi sampling rata-rata $\bar{x}$ tidak sama dengan standar deviasi populasi (kecuali jika $n=1$ ). Sebagai contoh untuk kasus $n=1$, misalkan suatu populasi terdiri dari tiga angka, yakni 1, 2, 3 . Misalkan dari populasi yang terdiri dari tiga angka tersebut, akan diambil sampel yang terdiri atas satu angka. Maka sampel-sampel yang mungkin adalah

$$
123 .
$$

Diketahui rata-rata dari setiap sampel tersebut adalah

$$
123 .
$$

Maka rata-rata dari distribusi sampling rata-rata $\bar{x}$ tersebut adalah

$$
\mu_{\bar{x}}=\frac{1+2+3}{3}=2 .
$$

Sedangkan standar deviasi dari distribusi sampling rata-rata $\bar{x}$ tersebut adalah

$$
\sigma_{\bar{x}}=\sqrt{\frac{(1-2)^{2}+(2-2)^{2}+(3-2)^{2}}{3}}=0,8165 \text {, }
$$

yang mana

$$
\sigma_{\bar{x}}=\sigma \quad(\text { ketika } n=1)
$$


Mann dan Christopher (2011:307) menyatakan rumus

$$
\sigma_{\bar{x}}=\frac{\sigma}{\sqrt{n}}
$$

berlaku ketika paling tidak memenuhi salah satu dari kriteria:

$\Rightarrow$ Jumlah elemen dalam populasi berhingga (finite) dan pengambilan elemen untuk sampel dari suatu populasi dengan pengembalian (with replacement).

$\Rightarrow$ Jumlah elemen dalam populasi tak berhingga (infinite) dan pengambilan elemen untuk sampel dari suatu populasi tanpa pengembalian (without replacement).

Namun kriteria-kriteria tersebut dapat diganti ketika ukuran sampel kecil (sample size is small) dalam perbandingannya terhadap ukuran populasi (in comparison to the population size). Ukuran sampel dapat dipandang (is considered) kecil dalam perbandingannya terhadap ukuran populasi ketika ukuran sampel lebih kecil atau sama dengan 5\% dari ukuran populasi, yakni

$$
\frac{n}{N} \leq 0,05
$$

dengan $n$ merupakan ukuran sampel dan $N$ ukuran populasi (Mann dan Christopher, 2011:307). Namun ketika tidak terpenuhi, maka penghitungan $\sigma_{\bar{x}}$ dihitung dengan rumus

$$
\sigma_{\bar{x}}=\frac{\sigma}{\sqrt{n}} \sqrt{\frac{N-n}{N-1}}
$$

di mana

$$
\sqrt{\frac{N-n}{N-1}}
$$

merupakan faktor koreksi populasi berhingga (Mann dan Christopher, 2011:307).

Berikut diberikan contoh kasus untuk perhitungan standar deviasi dari distribusi sampling $\bar{x}$ dengan rumus $\sigma_{\bar{x}}=\frac{\sigma}{\sqrt{n}}$. Misalkan suatu populasi terdiri dari tiga angka, yakni 1, 2, 3. Misalkan dari populasi yang terdiri dari tiga angka tersebut, akan diambil sampel yang terdiri atas dua angka dengan pengembalian (with replacement). Maka sampel-sampel yang mungkin adalah sebagai berikut. 


$\begin{array}{lll}(1,1) & (1,2) & (1,3) \\ (2,1) & (2,2) & (2,3) \\ (3,1) & (3,2) & (3,3)\end{array}$

Perhatikan bahwa karena jumlah elemen dalam populasi berhingga, yakni tiga, dan pengambilan elemen sampel dengan pengembalian, maka standar deviasi dari distribusi sampling rata-rata $\bar{x}$ dihitung dengan rumus sebagai berikut.

$$
\sigma_{\bar{x}}=\frac{\sigma}{\sqrt{n}}
$$

Hasil perhitungan rata-rata untuk setiap sampel sebagai berikut.

$\begin{array}{ccc}1 & 1,5 & 2 \\ 1,5 & 2 & 2,5 \\ 2 & 2,5 & 3\end{array}$

Maka rata-rata dari distribusi sampling rata-rata $\bar{x}$ tersebut adalah

$$
\mu_{\bar{x}}=\frac{1+1,5+2+1,5+2+2,5+2+2,5+3}{9}=\frac{18}{9}=2 .
$$

Berikut perhitungan standar deviasi dari distribusi sampling rata-rata $\bar{x}$.

$$
\begin{aligned}
& (1-2)^{2}(1,5-2)^{2} \quad(2-2)^{2} \\
& (1,5-2)^{2} \quad(2-2)^{2}(2,5-2)^{2} \\
& (2-2)^{2}(2,5-2)^{2} \quad(3-2)^{2}
\end{aligned}
$$

Maka diperoleh hasil sebagai berikut.

Sehingga

$\begin{array}{ccc}1 & 0,25 & 0 \\ 0,25 & 0 & 0,25 \\ 0 & 0,25 & 1\end{array}$

$$
\begin{gathered}
\sigma_{\bar{x}}=\sqrt{\frac{(1-2)^{2}+(1,5-2)^{2}+(2-2)^{2}+\cdots+(3-2)^{2}}{9}} \\
\sigma_{\bar{x}}=\sqrt{\frac{1+0,25+0+0,25+0+0,25+0+0,25+1}{9}}
\end{gathered}
$$


Bab 1. Pernak Pernik Statistik

$$
\sigma_{\bar{x}}=\sqrt{\frac{3}{9}}=\sqrt{0,3333333}=0,57735
$$

Perhatikan bahwa berdasarkan perhitungan sebelumnya diperoleh

$$
\begin{gathered}
\mu_{\bar{x}}=2 \\
\sigma_{\bar{x}}=0,57735 .
\end{gathered}
$$

Diketahui

$$
\begin{gathered}
\mu=\frac{1+2+3}{3}=2 \\
\sigma=\sqrt{\frac{(1-2)^{2}+(2-2)^{2}+(3-2)^{2}}{3}}=\sqrt{0,6666666}=0,81649658 .
\end{gathered}
$$

Perhatikan bahwa

$$
\sigma_{\bar{x}} \neq \sigma
$$

namun

$$
\begin{gathered}
\sigma_{\bar{x}}=\frac{\sigma}{\sqrt{n}} \\
0,57735=\frac{0,81649658}{\sqrt{2}} \\
0,57735=0,57735 .
\end{gathered}
$$

Berikut diberikan contoh kasus untuk perhitungan standar deviasi dari distribusi sampling $\bar{x}$ dengan rumus $\sigma_{\bar{x}}=\frac{\sigma}{\sqrt{n}} \sqrt{\frac{N-n}{N-1}}$. Misalkan suatu populasi terdiri dari tiga angka, yakni 1, 2, 3. Misalkan dari populasi yang terdiri dari tiga angka tersebut, akan diambil sampel yang terdiri atas dua angka tanpa pengembalian (without replacement). Maka sampel-sampel yang mungkin adalah

$$
(1,2) \quad(1,3) \quad(2,3)
$$

Perhatikan bahwa karena jumlah elemen dalam populasi berhingga, yakni tiga, namun pengambilan elemen sampel tanpa pengembalian, maka standar deviasi dari distribusi sampling rata-rata $\bar{x}$ dihitung dengan rumus sebagai berikut. 


$$
\sigma_{\bar{x}}=\frac{\sigma}{\sqrt{n}} \sqrt{\frac{N-n}{N-1}}
$$

Diketahui rata-rata dari setiap sampel tersebut adalah

$$
1,5 \quad 2,5,
$$

sehingga rata-rata dari distribusi sampling rata-rata $(\bar{x})$ tersebut adalah

$$
\mu_{\bar{x}}=\frac{1,5+2+2,5}{3}=\frac{6}{3}=2
$$

Standar deviasi dari distribusi sampling rata-rata $\bar{x}$ tersebut adalah

$$
\begin{gathered}
\sigma_{\bar{x}}=\sqrt{\frac{(1,5-2)^{2}+(2-2)^{2}+(2,5-2)^{2}}{3}} \\
\sigma_{\bar{x}}=\sqrt{\frac{0,25+0+0,25}{3}} \\
\sigma_{\bar{x}}=\sqrt{\frac{0,5}{3}}=\sqrt{0,16666667}=0,408248 .
\end{gathered}
$$

Perhatikan bahwa berdasarkan perhitungan sebelumnya diperoleh

$$
\begin{gathered}
\mu_{\bar{x}}=2 \\
\sigma_{\bar{x}}=0,408248 .
\end{gathered}
$$

Diketahui

$$
\begin{gathered}
\mu=\frac{1+2+3}{3}=2 \\
\sigma=\sqrt{\frac{(1-2)^{2}+(2-2)^{2}+(3-2)^{2}}{3}}=\sqrt{0,6666666}=0,81649658 .
\end{gathered}
$$

Perhatikan bahwa

$$
\sigma_{\bar{x}} \neq \sigma .
$$

Namun 


$$
\begin{gathered}
\sigma_{\bar{x}}=\frac{\sigma}{\sqrt{n}} \sqrt{\frac{N-n}{N-1}} \\
0,408248=\frac{0,81649658}{\sqrt{2}} \sqrt{\frac{3-2}{3-1}} \\
0,408248=\frac{0,81649658}{\sqrt{2}} \sqrt{\frac{1}{2}} \\
0,408248=\frac{0,81649658}{2} \\
0,408248=0,408248
\end{gathered}
$$

Beberapa hal penting mengenai distribusi sampling rata-rata $\bar{x}$, yakni:

$\Rightarrow$ Nilai standar deviasi dari distribusi sampling rata-rata $\bar{x}$ lebih kecil dibandingkan nilai standar deviasi populasi, yakni $\sigma_{\bar{x}}<\sigma$ ketika $n$ lebih besar dari 1 . Hal ini terlihat jelas dari rumus

$$
\sigma_{\bar{x}}=\frac{\sigma}{\sqrt{n}}
$$

Sebagai contoh misalkan $\sigma=20$ dan $n=4$, maka

$$
\sigma_{\bar{x}}=\frac{\sigma}{\sqrt{n}}=\frac{20}{\sqrt{4}}=10 .
$$

Perhatikan bahwa

$$
\begin{gathered}
\sigma_{\bar{x}}<\sigma \\
10<20
\end{gathered}
$$

$\Rightarrow$ Nilai dari standar deviasi dari distribusi sampling rata-rata $\bar{x}$ akan semakin mengecil ketika ukuran sampel $n$ semakin besar.

$$
\text { ketika } n \uparrow \text { maka } \sigma_{\bar{x}}=\frac{\sigma}{\sqrt{n}} \downarrow
$$

Sebagai contoh misalkan $\sigma=20$ dan $n=4$, maka

$$
\sigma_{\bar{x}}=\frac{\sigma}{\sqrt{n}}=\frac{20}{\sqrt{4}}=10 .
$$


Untuk $n=20$ maka

$$
\sigma_{\bar{x}}=\frac{\sigma}{\sqrt{n}}=\frac{20}{\sqrt{20}}=4,4721
$$

Untuk $n=50$ maka

$$
\sigma_{\bar{x}}=\frac{\sigma}{\sqrt{n}}=\frac{20}{\sqrt{50}}=2,828
$$

Untuk $n=100$ maka

$$
\sigma_{\bar{x}}=\frac{\sigma}{\sqrt{n}}=\frac{20}{\sqrt{100}}=2
$$

Perhatikan bahwa nilai $\sigma_{\bar{x}}$ semakin mengecil ketika ukuran sampel $n$ semakin besar. Suatu statistik dikatakan estimator konsisten jika nilai standar deviasi dari distribusi sampling statistik tersebut semakin mengecil ketika ukuran sampel $n$ semakin besar, sehingga statistik rata-rata $\bar{x}$ merupakan estimator konsisten dari parameter rata-rata $\mu$ (Mann dan Christopher, 2011:307)

Standar deviasi dari distribusi sampling rata-rata $\bar{x}$ merupakan suatu nilai yang mengukur pencaran atau sebaran dari rata-rata sampel dari distribusi sampling rata-rata $\bar{x}$ terhadap rata-rata populasinya $\mu$. Semakin kecil nilai standar deviasi dari distribusi sampling rata-rata $\bar{x}$, maka rata-rata sampel dari distribusi sampling rata-rata $\bar{x}$ semakin mengumpul atau lebih dekat terhadap rata-rata populasinya $\mu$. Pada pembahasan sebelumnya, diketahui untuk untuk $n=20$ diperoleh $\sigma_{\bar{x}}=4,4721$, untuk $n=50$ diperoleh $\sigma_{\bar{x}}=2,828$, dan untuk $n=$ 100 diperoleh $\sigma_{\bar{x}}=2$. Perhatikan ilustrasi gambar berikut ini (Gambar 1.4).

\section{Gambar 1.4}
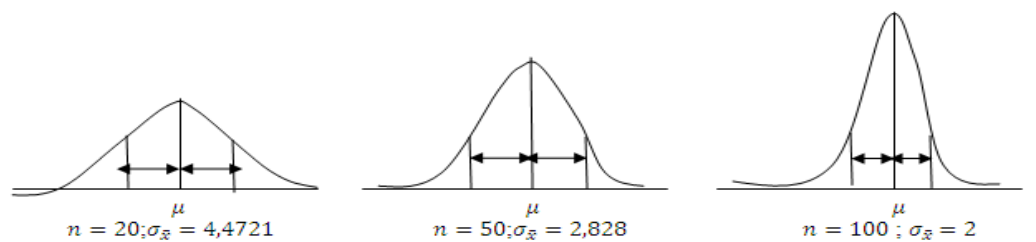

\section{Bentuk Distríbusi Sampling dari Rata-Rata $\bar{x}$}

Mann dan Christopher (2011:310) menyatakan bentuk distribusi sampling dari rata-rata $\bar{x}$ berkenaan (relates) atas dua hal, yakni:

$\Rightarrow$ Sampel yang ditarik dari populasi yang berdistribusi normal. 
$\Rightarrow$ Sampel yang ditarik dari populasi yang tidak berdistribusi normal.

Jika sampel-sampel yang ditarik berasal dari populasi yang berdistribusi normal dengan rata-rata dan standar deviasi masing-masing $\mu$ dan $\sigma$, maka:

$\Rightarrow$ Rata-rata distribusi sampling rata-rata $\bar{x}$ sama dengan rata-rata populasi, yakni $\mu_{\bar{x}}=\mu$.

$\Rightarrow$ Standar deviasi distribusi sampling rata-rata $\bar{x}$ sama dengan $\frac{\sigma}{\sqrt{n}}$, dengan $n / N \leq 0,05$.

$\Rightarrow$ Bentuk dari distribusi sampling rata-rata $\bar{x}$ berbentuk normal, untuk berapapun ukuran sampel $n$.

Jadi, jika sampel-sampel yang ditarik berasal dari populasi yang berdistribusi normal dengan rata-rata adalah $\mu$ dan standar deviasi adalah $\sigma$, maka distribusi sampling dari rata-rata $\bar{x}$ juga terdistribusi secara normal, dengan rata-rata dan standar deviasi

$$
\mu_{\bar{x}}=\bar{x} ; \quad \sigma_{\bar{x}}=\frac{\sigma}{\sqrt{n}} \quad ; \frac{n}{N} \leq 0,05
$$

Perhatikan gambar berikut ini.

\section{Gambar 1.5}

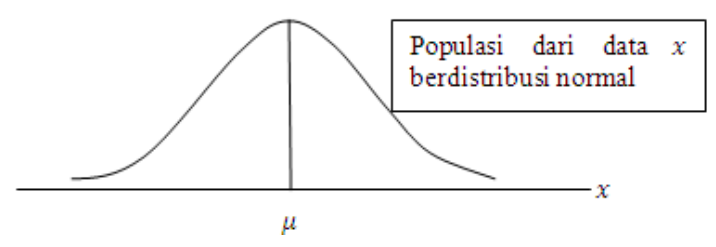

Gambar 1.6

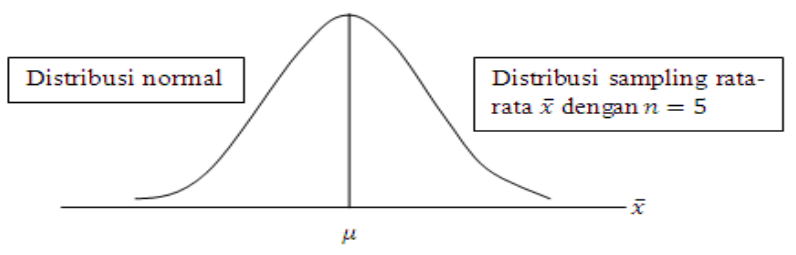

Gambar 1.7 


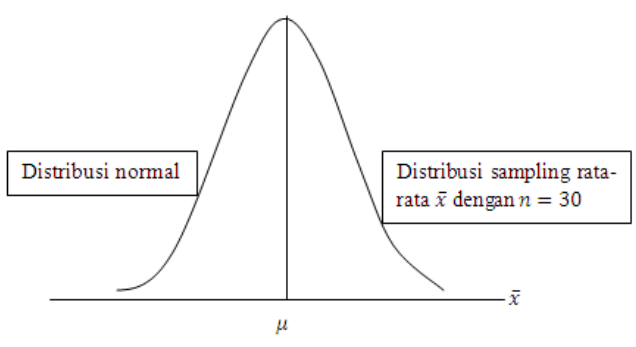

Gambar 1.8

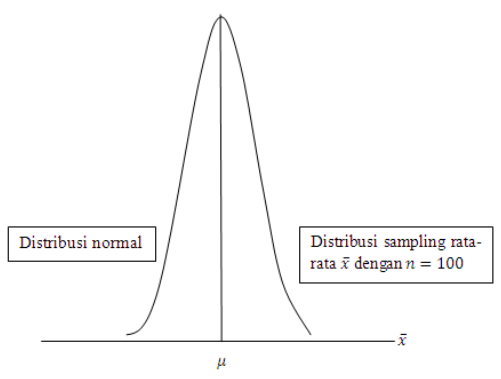

Perhatikan bahwa pada Gambar 1.5 menjelaskan data $x$ berasal dari populasi berdistribusi normal. Pada Gambar 1.6 merupakan kurva dari distribusi sampling rata-rata $\bar{x}$ dengan $n=5$. Pada Gambar 1.7 merupakan kurva dari distribusi sampling rata-rata $\bar{x}$ dengan $n=30$. Pada Gambar 1.8 merupakan kurva dari distribusi sampling rata-rata $\bar{x}$ dengan $n=100$. Perhatikan bahwa karena sampel-sampel ditarik dari populasi yang berdistribusi normal, maka kurva dari distribusi sampling rata-rata $\bar{x}$ membentuk kurva normal (Gambar 1.6 sampai Gambar 1.8).

Perhatikan bahwa standar deviasi dari distribusi sampling rata-rata $\bar{x}$ pada Gambar 1.7 lebih kecil daripada Gambar 1.6, standar deviasi dari distribusi sampling rata-rata $\bar{x}$ pada Gambar 1.8 lebih kecil daripada Gambar 1.7. Perhatikan bahwa semakin besar ukuran sampel, maka akan semakin kecil nilai standar deviasi dari distribusi sampling rata-rata $\bar{x}$. Dalam prakteknya, seringkali populasi yang diteliti tidak berdistribusi normal. Teorema yang sangat penting untuk menyimpulkan bentuk dari distribusi sampling rata-rata $\bar{x}$ adalah Teorema Limit Sentral (Central Limit Theorem).

Teorema limit sentral menyatakan bahwa untuk sampel berukuran besar, distribusi sampling rata-rata $\bar{x}$ akan mendekati normal, tidak perduli apakah sampel-sampel tersebut ditarik dari populasi yang berdistribusi normal atau tidak, dengan rata-rata dan standar deviasi dari distribusi sampling rata-rata $\bar{x}$ sebagai berikut.

$$
\mu_{\bar{x}}=\mu \quad \text { dan } \quad \sigma_{\bar{x}}=\frac{\sigma}{\sqrt{n}}
$$


Ukuran sampel $n$ dipertimbangkan cukup besar, yakni $n \geq 30$.

Berdasarkan teorema limit sentral, perlu diperhatikan bahwa, jika populasi tidak berdistribusi normal, bentuk dari distribusi sampling rata-rata $\bar{x}$ tidak secara tepat normal, namun mendekati normal, ketika sampel berukuran besar. Semakin besar ukuran sampel, maka bentuk dari distribusi sampling rata-rata $(\bar{x})$ akan semakin mendekati normal (Mann dan Christopher, 2011:313).

Berdasarkan teori limit sentral,

$\Rightarrow$ Ketika ukuran sampel $n \geq 30$, maka bentuk dari distribusi sampling rata-rata $(\bar{x})$ mendekati normal, tidak perduli apakah sampel-sampel tersebut ditarik dari populasi berdistribusi normal atau tidak.

$\Rightarrow$ Rata-rata dari distribusi sampling rata-rata $(\bar{x})$, yakni $\mu_{\bar{x}}$ sama dengan rata-rata populasi, yakni $\mu$.

$\Rightarrow$ Standar deviasi dari distribusi sampling rata-rata $(\bar{x})$, yakni $\sigma_{\bar{x}}$ sama dengan $\sigma / \sqrt{n}$ dengan syarat $n / N \leq 0,05$.

Perhatikan ilustrasi gambar berikut.

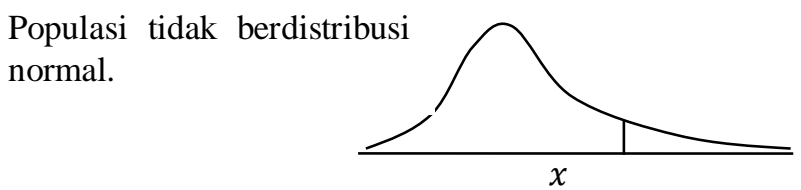

Distribusi sampling dari $\bar{x}$ untuk $n=4$.

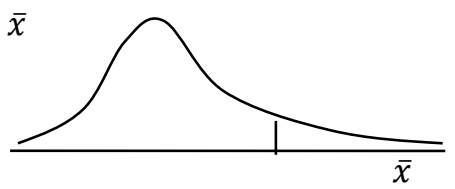

Distribusi sampling dari $\bar{x}$ untuk $n=15$.

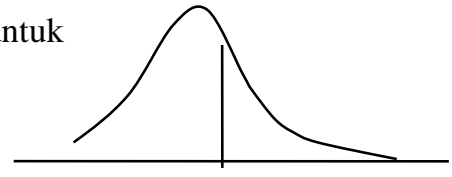

Distribusi sampling dari $\bar{x}$ untuk $n=30$.

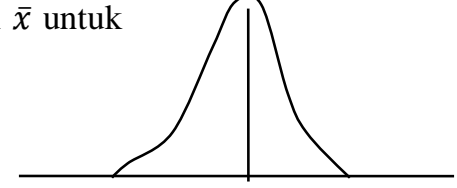

Berdasarkan gambar tersebut, populasi tidak berdistribusi normal. Semakin meningkat ukuran sampel, maka distribusi sampling rata-rata $\bar{x}$ semakin 
berbentuk distribusi normal. Semakin meningkat ukuran sampel, semakin kecil nilai standar deviasi dari distribusi sampling rata-rata $\bar{x}$.

\section{Referensi}

1. Agresti, A. dan B. Finlay. 2009. Statistical Methods for the Social Sciences, $4^{\text {th }}$ Edition. United States of America: Prentice Hall.

2. Daniel, W.W. 2005. Biostatistics, A Foundation for Analysis in the Health Sciences, $8^{\text {th }}$ Edition, John Wiley \& Sons, Inc.

3. Field, A. 2009. Discovering Statistics Using SPSS, $3^{\text {rd }}$ Edition. London: Sage.

4. Gio, P.U. 2013. Aplikasi Statistika dalam SPSS. Medan: USUpress.

5. Mann, P. S. dan Christopher, J.L. 2011. Introductory Statistics, International Student Version, $7^{\text {th }}$ Edition. Asia: John Wiley \& Sons, Inc.

6. Montgomery, D. C. dan G. C. Runger. 2011. Applied Statistics and Probability for Engineers, $5^{\text {th }}$ Edition. United States of America: John Wiley \& Sons, Inc.

7. Ott, R.L. dan M. Longnecker. 2001. An Introduction to Statistical Methods and Data Analysis, $5^{\text {th }}$ Edition. United States of America: Duxbury.

8. Smidth, R. K. dan D. H. Sanders. 2000. Statistics a First Course, $6^{\text {th }}$ Edition. United States of America: McGraw-Hill Companies. 


\section{Bab 2}

\section{REGRESI LINEAR BERGANDA}

\section{Sekilas Regresi Línear Berganda}

Persamaan regresi merupakan suatu persamaan yang menerangkan atau menjelaskan hubungan antara variabel bebas dan variabel tak bebas. Persamaan regresi dapat digunakan untuk memprediksi atau mengestimasi nilai dari variabel tak bebas berdasarkan informasi dari variabel bebas. Persamaan regresi linear merupakan suatu persamaan yang berupa garis lurus, sedangkan persamaan regresi nonlinear bukan merupakan persamaan garis lurus (Gambar 2.1).

\section{Gambar 2.1}

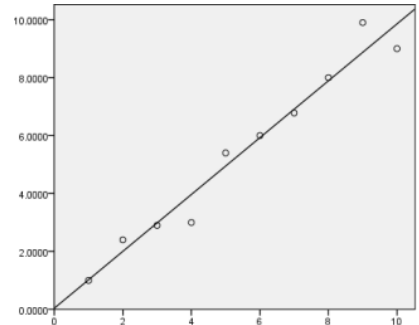

Persamaan Regresi Linear

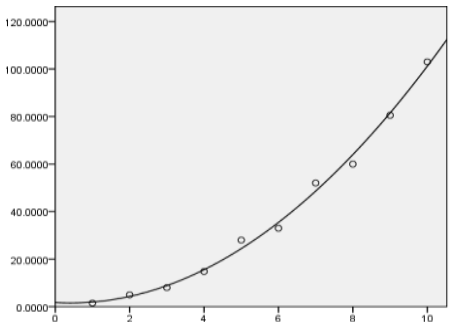

Persamaan Regresi Nonlinear

Persamaan regresi linear hanya melibatkan satu variabel tak bebas, namun jumlah variabel bebas dapat lebih dari satu. Jika persamaan regresi linear hanya menggunakan satu variabel bebas, maka persamaan regresi linear tersebut disebut persamaan regresi linear sederhana (simple linear regression). Namun, jika jumlah variabel bebas pada persamaan regresi linear lebih dari satu, maka persamaan regresi linear tersebut disebut persamaan regresi linear berganda (multiple linear regression). Dalam regresi linear sederhana atau berganda, baik variabel bebas maupun variabel tak bebas bersifat metrik (interval atau rasio) (Hair, 2010:151). Sebagai contoh data bersifat metrik, seperti gaji pegawai, tinggi badan, berat badan, umur manusia, jumlah produksi beras, dan sebagainya. Berikut diberikan contoh aplikasi dari regresi linear sederhana. 
$\Rightarrow$ Membuat persamaan atau model untuk memprediksi atau mengestimasi nilai indeks prestasi mahasiswa berdasarkan jumlah jam belajar dalam sehari. Di samping itu dapat diketahui seberapa besar kontribusi yang diberikan faktor jumlah jam belajar dalam sehari terhadap indeks prestasi.

$\Rightarrow$ Membuat persamaan atau model untuk memprediksi atau mengestimasi laba perusahaan berdasarkan tingkat penjualan perusahaan. Di samping itu dapat diketahui seberapa besar kontribusi yang diberikan dari faktor tingkat penjualan perusahaan terhadap naik/turunnya laba perusahaan.

$\Rightarrow$ Membuat persamaan atau model untuk memprediksi atau mengestimasi return saham suatu perusahaan berdasarkan laba kotor perusahaan.

Dalam regresi linear sederhana hanya melibatkan satu variabel bebas dalam membuat persamaan regresi, sedangkan pada regresi linear berganda melibatkan dua atau lebih variabel bebas. Variabel bebas bersifat metrik (interval atau rasio) (Hair, 2010:151). Penggunaan lebih dari satu variabel bebas dalam pembuatan persamaan regresi linear dimaksudkan agar persamaan regresi linear yang dihasilkan lebih mampu menerangkan atau menjelaskan karakteristik dari variabel tak bebas. Contoh aplikasi dari regresi linear berganda sebagai berikut.

$\Rightarrow$ Membuat persamaan untuk memprediksi atau mengestimasi nilai indeks prestasi mahasiswa berdasarkan jumlah jam belajar dalam sehari dan intelligence quotient (IQ). Di samping itu dapat diketahui faktor-faktor yang memberikan kontribusi paling besar dalam hal pengaruhnya terhadap indeks prestasi mahasiswa.

$\Rightarrow$ Membuat model untuk memprediksi atau mengestimasi laba perusahaan berdasarkan umur perusahaan, tingkat penjualan, dan besarnya perusahaan. Di samping itu, dapat diketahui seberapa besar kontribusi yang diberikan dari faktor umur perusahaan terhadap naik/turunnya laba perusahaan, dengan mengontrol pengaruh tingkat penjualan dan besarnya perusahaan. Dapat juga diketahui seberapa besar kontribusi yang diberikan dari faktor tingkat penjualan perusahaan terhadap naik/turunnya laba perusahaan, dengan mengontrol pengaruh umur perusahaan dan besarnya perusahaan.

$\Rightarrow$ Membuat persamaan untuk memprediksi atau mengestimasi harga saham suatu perusahaan berdasarkan laba per-lembar saham dan jumlah kas dividen yang diberikan. Di samping itu, dapat diketahui seberapa besar kontribusi yang diberikan dari faktor laba per-lembar saham terhadap naik/turunnya harga saham, dengan mengontrol pengaruh jumlah kas dividen yang diberikan. 


\section{Mengukur Kecocokkan Model Regresí Línear Berganda terhadap Data dengan Koefisien Determinasi $\left(r^{2}\right)$}

Dalam regresi linear, baik sederhana maupun berganda, koefisien determinasi $\left(r^{2}\right)$ digunakan untuk mengukur kemampuan model regresi linear dalam mencocokkan atau menyesuaikan (fits) data. Jika koefisien determinasi dari model regresi linear bernilai 1, maka model tersebut menyesuaikan atau mencocokkan data secara sempurna (Gambar 2.2). Jika koefisien determinasi dari model regresi linear bernilai mendekati 0 , maka model tersebut kurang baik dalam menyesuaikan atau mencocokkan data (Gambar 2.3).

Pada Gambar 2.2, model regresi linear secara sempurna dalam mencocokkan atau menyesuaikan data (titik-titik). Nilai koefisien determinasi bernilai 1. Pada Gambar 2.3, model regresi linear kurang baik dalam mencocokkan atau menyesuaikan data (titik-titik). Hal ini karena titik-titik menyebar cukup jauh dari model regresi linear. Nilai koefisien determinasi yang semakin dekat dengan 1 menunjukkan semakin baik kemampuan model regresi linear dalam mencocokkan atau menyesuaikan (fits) data. Dengan kata lain kemampuan variabel-variabel bebas dalam menjelaskan variabel tak bebas semakin baik.

\section{Gambar 2.2}

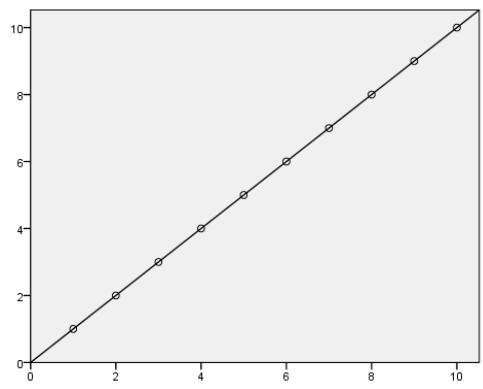

Gambar 2.3

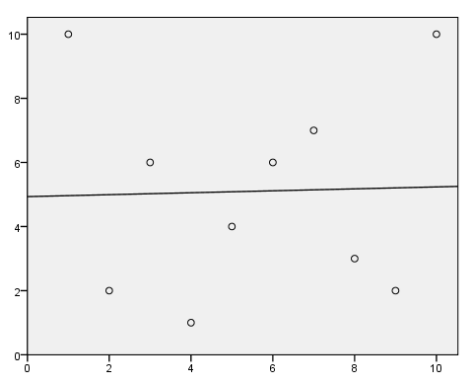

\section{Menguji Sígnifikansi Kecocokkan Model Regresi Linear Berganda terhadap Data dengan Uji $F$}

Dalam regresi linear berganda, uji $F$ digunakan untuk menguji signifikansi kecocokkan model regresi linear berganda terhadap data. Dengan kata lain, uji $F$ menguji signifikansi seluruh koefisien regresi populasi secara simultan (simultaneously) atau bersamaan. Berikut perumusan hipotesis untuk uji $F$.

$$
H_{0}: \beta_{1}=\beta_{2}=\cdots=\beta_{k}=0 .
$$

$H_{1}$ : Paling tidak terdapat satu koefisien regresi populasi yang tidak sama dengan nol. 
Perhatikan bahwa hipotesis nol menyatakan seluruh koefisien regresi populasi bernilai nol. Dengan kata lain, seluruh variabel memiliki pengaruh yang tidak signifikan secara statistik terhadap variabel tak bebas. Hipotesis alternatif menyatakan bahwa paling tidak terdapat satu koefisien regresi populasi yang tidak bernilai nol. Dengan kata lain, paling tidak terdapat satu variabel bebas yang memiliki pengaruh signifikan secara statistik terhadap variabel tak bebas.

Untuk pengambilan keputusan terhadap hipotesis, dapat dilakukan dengan membandingkan nilai statistik dari uji $F\left(F_{\text {hitung }}\right)$ terhadap nilai kritis berdasarkan tabel distribusi $F$ (atau $F$ tabel). Sebelum menghitung nilai kritis $F$, terlebih dahulu menghitung nilai derajat bebas pembilang dan derajat bebas penyebut. Berikut rumus untuk menghitung nilai derajat bebas pembilang dan penyebut.

\section{Derajat bebas pembilang $=k-1$.$$
\text { Derajat bebas penyebut }=n-k \text {. }
$$

Perhatikan bahwa $n$ menyatakan jumlah elemen atau pengamatan dalam sampel dan $k$ menyatakan jumlah variabel. Andaikan melibatkan 2 variabel bebas, 1 variabel tak bebas, serta jumlah elemen sampel sebanyak 10, maka derajat bebas pembilang adalah $k-1=(2+1)-1=2$ dan derajat bebas penyebut adalah $10-3=7$. Misalkan tingkat signifikansi yang digunakan adalah $5 \%$. Maka nilai kritis $F$ (atau $F$ tabel) dengan derajat bebas pembilang adalah 2, derajat bebas penyebut adalah 7 , dan tingkat signifikansi $5 \%$ adalah 4,74 . Berikut aturan pengambilan keputusan terhadap hipotesis berdasarkan uji $F$.

Jika $F_{\text {hitung }} \leq F_{\text {kritis }}, H_{0}$ diterima dan $H_{1}$ ditolak.
Jika $F_{\text {hitung }}>F_{\text {kritis }}, H_{0}$ ditolak dan $H_{1}$ diterima.

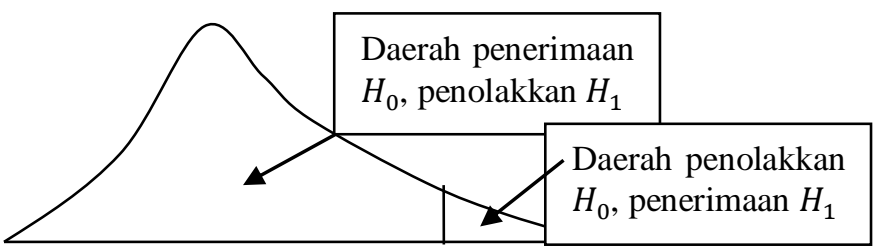

$$
F_{\text {kritis }}=4,74
$$

Pengambilan keputusan terhadap hipotesis juga dapat dilakukan dengan menggunakan pendekatan nilai probabilitas dari uji $F$. Nilai probabilitas dari uji $F$ dibandingkan dengan tingkat signifikansi yang digunakan. Berikut aturan pengambilan keputusan terhadap hipotesis berdasarkan pendekatan nilai probabilitas.

Jika nilai probabilitas $\geq \alpha, H_{0}$ diterima dan $H_{1}$ ditolak. Jika nilai probabilitas $<\alpha, H_{0}$ ditolak dan $H_{1}$ diterima.

Perhatikan bahwa $\boldsymbol{\alpha}$ merupakan tingkat signifikansi. 


\section{Uji Signifikansi Koefísien Regresi Secara Indivídu dengan Ujit}

Dalam regresi linear berganda, uji $t$ digunakan untuk menguji signifikansi dari masing-masing koefisien regresi populasi. Signifikansi koefisien regresi populasi diuji berdasarkan koefisien regresi sampel. Berikut perumusan hipotesis untuk uji signifikansi koefisien regresi secara individu.

$$
\begin{aligned}
& H_{0}: \beta_{i}=0 . \\
& H_{1}: \beta_{i} \neq 0 .
\end{aligned}
$$

Perhatikan bahwa hipotesis nol menyatakan koefisien regresi populasi ke- $i\left(\beta_{i}\right)$ bernilai nol. Dengan kata lain, variabel bebas ke- $i$ memiliki pengaruh yang tidak signifikan secara statistik terhadap variabel tak bebas, dengan mengontrol pengaruh dari variabel bebas lain. Hipotesis alternatif menyatakan koefisien regresi populasi ke- $i\left(\beta_{i}\right)$ tidak bernilai nol. Dengan kata lain, variabel bebas ke- $i$ memiliki pengaruh yang signifikan secara statistik terhadap variabel tak bebas, dengan mengontrol pengaruh dari variabel bebas lain.

Untuk pengambilan keputusan terhadap hipotesis, dapat dilakukan dengan membandingkan nilai statistik dari uji $t$ terhadap nilai kritis berdasarkan tabel distribusi $t$ ( $t$ tabel). Sebelum menghitung nilai kritis $t$, terlebih dahulu menghitung nilai derajat. Berikut rumus untuk menghitung nilai derajat bebas.

$$
\text { Derajat bebas }=n-k \text {. }
$$

Perhatikan bahwa $n$ menyatakan jumlah elemen dalam sampel, sedangkan $k$ merupakan jumlah variabel. Andaikan jumlah elemen dalam sampel sebanyak 10 dan jumlah variabel adalah 3 (jumlah variabel bebas adalah 2 dan variabel tak bebas adalah 1), sehingga derajat bebas adalah $10-3=7$. Misalkan tingkat signifikansi yang digunakan adalah 5\%, sehingga nilai kritis $t$ ( $t$ tabel) dengan derajat bebas 7 dan tingkat signifikansi 5\% berdasarkan tabel distribusi $t$ adalah $\pm 2,365$. Berikut aturan pengambilan keputusan terhadap hipotesis berdasarkan uji $t$.

$$
\begin{aligned}
& \text { Jika }\left|t_{\text {hitung }}\right| \leq\left|t_{\text {kritis }}\right|, H_{0} \text { diterima dan } H_{1} \text { ditolak. } \\
& \text { Jika }\left|t_{\text {hitung }}\right|>\left|t_{\text {kritis }}\right|, H_{0} \text { ditolak dan } H_{1} \text { diterima. }
\end{aligned}
$$

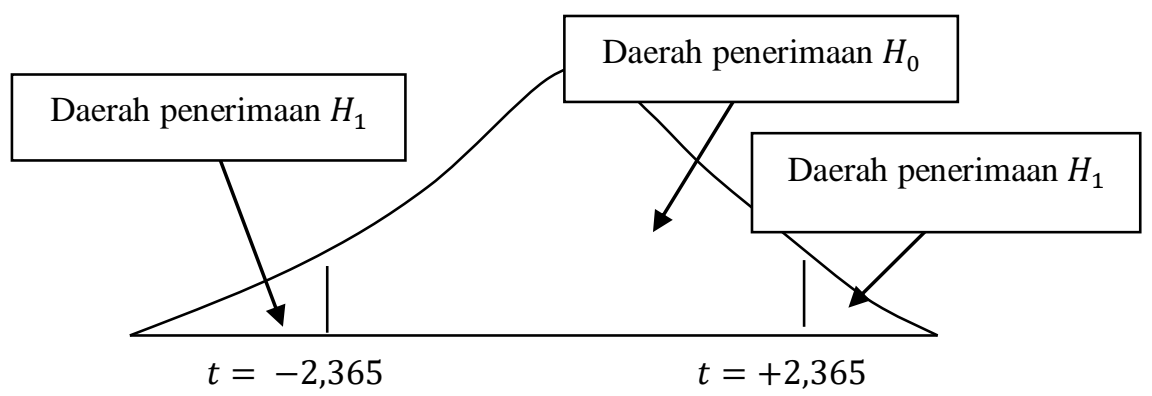


Pengambilan keputusan terhadap hipotesis juga dapat dilakukan dengan menggunakan pendekatan nilai probabilitas dari uji $t$. Nilai probabilitas dari uji $t$ dibandingkan dengan tingkat signifikansi yang digunakan. Berikut aturan pengambilan keputusan terhadap hipotesis berdasarkan pendekatan nilai probabilitas.

Jika nilai probabilitas $\geq \alpha, H_{0}$ diterima dan $H_{1}$ ditolak. Jika nilai probabilitas $<\alpha, H_{0}$ diterima dan $H_{1}$ ditolak.

\section{Contoh Kasus dalam Regresi Línear Berganda}

Berikut diberikan contoh kasus yang dapat diselesaikan dengan pendekatan regresi linear berganda.

[1] Misalkan seorang peneliti bernama Ugi ingin membuat model regresi linear berganda dengan menggunakan variabel berat badan $(Y)$ sebagai variabel tak bebas, variabel tinggi badan $\left(X_{1}\right)$ dan usia $\left(X_{2}\right)$ sebagai variabel bebas. Data yang telah dikumpulkan oleh Ugi disajikan dalam Tabel 2.1.

Berdasarkan data pada Tabel 2.1, jumlah responden yang diteliti sebanyak $n=$ 30 responden. Responden yang diteliti dalam hal ini adalah anak laki-laki. Diketahui responden ke-2 memiliki tinggi $130 \mathrm{~cm}$, usia 15 tahun, dan berat 52 $\mathrm{kg}$. Responden ke-28 memiliki tinggi $127 \mathrm{~cm}$, usia 14 tahun, dan berat $59 \mathrm{~kg}$.

Tabel 2.1 (Data Fiktif)

\begin{tabular}{|c|c|c|c|c|c|c|c|}
\hline Responden & $Y$ & $X_{1}$ & $X_{2}$ & Responden & $Y$ & $X_{1}$ & $X_{2}$ \\
\hline 1 & 45 & 128 & 13 & 16 & 46 & 129 & 14 \\
\hline 2 & 52 & 130 & 15 & 17 & 53 & 131 & 16 \\
\hline 3 & 34 & 120 & 10 & 18 & 35 & 121 & 11 \\
\hline 4 & 48 & 133 & 13 & 19 & 49 & 134 & 14 \\
\hline 5 & 36 & 122 & 11 & 20 & 37 & 123 & 12 \\
\hline 6 & 39 & 121 & 12 & 21 & 40 & 122 & 13 \\
\hline 7 & 58 & 126 & 16 & 22 & 59 & 127 & 17 \\
\hline 8 & 38 & 119 & 11 & 23 & 39 & 120 & 12 \\
\hline 9 & 37 & 123 & 10 & 24 & 38 & 124 & 11 \\
\hline 10 & 32 & 123 & 8 & 25 & 33 & 124 & 9 \\
\hline 11 & 57 & 132 & 14 & 26 & 58 & 133 & 15 \\
\hline 12 & 49 & 128 & 12 & 27 & 50 & 129 & 13 \\
\hline 13 & 58 & 126 & 13 & 28 & 59 & 127 & 14 \\
\hline 14 & 38 & 119 & 8 & 29 & 39 & 120 & 9 \\
\hline 15 & 37 & 123 & 11 & 30 & 38 & 124 & 12 \\
\hline
\end{tabular}


Berikut hal-hal yang ingin dilakukan oleh peneliti.

$\Rightarrow$ Membuat persamaan regresi linear berganda yang menerangkan hubungan berat $(\mathrm{kg})$ terhadap tinggi $(\mathrm{cm})$ dan usia (tahun).

$\Rightarrow$ Menentukan seberapa besar faktor tinggi berkontribusi dalam hal naik/turunnya berat badan, dengan mengontrol pengaruh usia.

$\Rightarrow$ Menentukan seberapa besar faktor usia berkontribusi dalam hal naik/turunnya berat badan, dengan mengontrol pengaruh tinggi.

$\Rightarrow$ Menentukan faktor yang memberikan kontribusi paling besar terhadap naik/turunnya berat badan.

$\Rightarrow$ Mengestimasi atau memprediksi berat badan seoarang anak laki-laki, ketika memiliki tinggi $135 \mathrm{~cm}$ dan usia 14 tahun.

[2] Misalkan seorang peneliti bernama Ugi ingin membuat persamaan regresi linear berganda dengan menggunakan variabel indeks prestasi $(Y)$ sebagai variabel tak bebas, variabel jumlah jam belajar dalam sehari $\left(X_{1}\right)$ dan IQ $\left(X_{2}\right)$ sebagai variabel bebas. Data yang telah dikumpulkan oleh Ugi disajikan dalam Tabel 2.2.

Berdasarkan data pada Tabel 2.2, jumlah responden yang diteliti sebanyak $n=$ 20 responden. Responden yang diteliti dalam hal ini adalah mahasiswa matematika semester 2. Diketahui responden ke-2 menghabiskan waktu untuk belajar dalam sehari selama 12 jam, memiliki IQ 106, dan meraih IP 3,15. Responden ke-15 menghabiskan waktu untuk belajar dalam sehari selama 9 jam, memiliki IQ 99, dan meraih IP 2,75.

Tabel 2.2 (Data Fiktif)

\begin{tabular}{|c|c|c|c|c|c|c|c|}
\hline Responden & $X_{1}$ & $X_{2}$ & $Y$ & Responden & $X_{1}$ & $X_{2}$ & $Y$ \\
\hline 1 & 10 & 103 & 3.01 & 11 & 11 & 105 & 3.06 \\
\hline 2 & 12 & 106 & 3.15 & 12 & 13 & 108 & 3.2 \\
\hline 3 & 9 & 104 & 2.9 & 13 & 10 & 106 & 2.95 \\
\hline 4 & 10 & 109 & 3.1 & 14 & 11 & 111 & 3.15 \\
\hline 5 & 8 & 97 & 2.7 & 15 & 9 & 99 & 2.75 \\
\hline 6 & 11 & 114 & 3.25 & 16 & 12 & 116 & 3.3 \\
\hline 7 & 15 & 118 & 3.6 & 17 & 16 & 120 & 3.65 \\
\hline 8 & 17 & 117 & 3.7 & 18 & 18 & 119 & 3.75 \\
\hline 9 & 16 & 112 & 3.65 & 19 & 17 & 114 & 3.7 \\
\hline 10 & 10 & 107 & 3.15 & 20 & 11 & 109 & 3.2 \\
\hline
\end{tabular}


Berikut hal-hal yang ingin dilakukan oleh peneliti.

$\Rightarrow$ Membuat persamaan regresi linear berganda yang menerangkan hubungan IP terhadap jumlah jam belajar dalam sehari dan IQ.

$\Rightarrow$ Menentukan seberapa besar faktor jumlah jam belajar dalam sehari berkontribusi dalam hal naik/turunnya IP, dengan mengontrol pengaruh IQ.

$\Rightarrow$ Menentukan seberapa besar faktor IQ berkontribusi dalam hal naik/turunnya IP, dengan mengontrol pengaruh jumlah jam belajar dalam sehari.

$\Rightarrow$ Menentukan faktor yang memberikan kontribusi paling besar terhadap naik/turunnya IP.

$\Rightarrow$ Mengestimasi atau memprediksi IP mahasiswa, ketika mahasiswa menghabiskan waktu belajar dalam sehari 11 jam dan IQ 113.

[3] Misalkan seorang peneliti bernama Ugi ingin membuat persamaan regresi linear berganda dengan menggunakan variabel pengeluaran per-bulan $(Y)$ sebagai variabel tak bebas, variabel penghasilan per-bulan $\left(X_{1}\right)$, jumlah anggota keluarga $\left(X_{2}\right)$ dan jumlah kendaraan $\left(X_{3}\right)$ sebagai variabel bebas. Data yang telah dikumpulkan oleh Ugi disajikan dalam Tabel 2.3.

\section{Tabel 2.3 (Data Fiktif)}

\begin{tabular}{|c|c|c|c|c|c|c|c|c|c|}
\hline Keluarga & $X_{1}$ & $X_{2}$ & $X_{3}$ & $Y$ & Keluarga & $X_{1}$ & $X_{2}$ & $X_{3}$ & $Y$ \\
\hline 1 & 8 & 4 & 5 & 5.5 & 11 & 8 & 4 & 5 & 5.5 \\
\hline 2 & 8.1 & 5 & 6 & 6.5 & 12 & 8.1 & 5 & 6 & 6.5 \\
\hline 3 & 9 & 4 & 7 & 7 & 13 & 9 & 4 & 7 & 7 \\
\hline 4 & 6 & 4 & 2 & 4.5 & 14 & 6 & 4 & 2 & 4.5 \\
\hline 5 & 5.2 & 3 & 2 & 3.6 & 15 & 5.2 & 3 & 2 & 3.6 \\
\hline 6 & 5 & 4 & 3 & 3.4 & 16 & 5 & 4 & 3 & 3.4 \\
\hline 7 & 4.5 & 2 & 3 & 4 & 17 & 4.5 & 2 & 3 & 4 \\
\hline 8 & 4 & 4 & 4 & 4.5 & 18 & 4 & 4 & 4 & 4.5 \\
\hline 9 & 5 & 5 & 4 & 4 & 19 & 5 & 5 & 4 & 4 \\
\hline 10 & 4.2 & 3 & 3 & 3 & 20 & 4.2 & 3 & 3 & 3 \\
\hline
\end{tabular}

Berdasarkan data pada Tabel 2.3, jumlah responden yang diteliti sebanyak $n=$ 20 responden (keluarga). Diketahui keluarga ke-2 memiliki penghasilan perbulan 8,1 juta, jumlah anggota keluarga sebanyak 5, jumlah kendaraan yang dimiliki sebanyak 6 kendaraan, dan pengeluaran per-bulan sebesar 6,5 juta. 
Berikut hal-hal yang ingin dilakukan oleh peneliti.

$\Rightarrow$ Membuat persamaan regresi linear berganda yang menerangkan hubungan pengeluaran per-bulan terhadap penghasilan per-bulan, jumlah anggota keluarga, dan jumlah kendaraan.

$\Rightarrow$ Menentukan seberapa besar faktor penghasilan per-bulan berkontribusi dalam hal naik/turunnya pengeluaran per-bulan, dengan mengontrol pengaruh jumlah anggota keluarga dan jumlah kendaraan.

$\Rightarrow$ Menentukan seberapa besar faktor jumlah kendaraan berkontribusi dalam hal naik/turunnya pengeluaran per-bulan, dengan mengontrol pengaruh jumlah anggota keluarga dan penghasilan per-bulan.

$\Rightarrow$ Menentukan faktor yang memberikan kontribusi paling besar terhadap naik/turunnya pengeluaran per-bulan.

$\Rightarrow$ Mengestimasi atau memprediksi pengeluaran per-bulan suatu keluarga, ketika memiliki pengasilan per-bulan 5 juta, jumlah anggota keluarga sebanyak 3, dan jumlah kendaraan sebanyak 2 kendaraan.

\section{Asumsi-Asumsi dalam Regresí Línear Berganda}

Terdapat beberapa asumsi yang dikenakan dalam penggunaan regresi linear berganda. Beberapa di antaranya adalah asumsi normalitas dari error, tidak terjadi multikolinearitas, non-autokorelasi, dan homoskedastisitas.

\section{Asumsi Normalitas}

Gujarati (2003:107) mengemukakan dalam penggunaan metode estimasi ordinary least squares (OLS) pada regresi linear berganda untuk tujuan pengujian hipotesis (hypothesis testing) terhadap estimasi-estimasi parameter dikenakan asumsi normalitas. Asumsi normalitas yang dimaksud adalah distribusi dari error (e) menyebar secara normal. Field (2009:221) menyatakan sebagai berikut.

"Normally distributed errors: It is assumed that the residuals in the model are random, normally distributed variables, with mean of 0 . This assumption simply means that the differences between the model and the observed data are most frequently zero or very close to zero, and that differences much greater than zero happen only occasionally. Some people confuse this assumption with the idea that predictors have to be normally distributed. In fact, predictors do not need to be normally distributed". 
Dalam hal ini, asumsi normalitas berarti distribusi dari error (e) menyebar secara normal, dan variabel-variabel bebas tidak harus berdistribusi normal. Stevens (2009:90) juga menyatakan sebagai berikut.

"Recal that in linear regression model, it is assumed that the errors are independent and follow a normal distribution with constant variance. The normality assumption can be checked through use of the histogram of the standardized or studentized residuals".

Error merupakan selisih antara nilai variabel tak bebas $(Y)$ dan estimasi dari nilai variabel tak bebas $(\hat{Y})$. Nilai estimasi dari variabel tak bebas diperoleh berdasarkan persamaan regresi. Untuk menguji asumsi normalitas dapat digunakan pendekatan analisis grafik, yakni $Q-Q$ (quantile-quantile) plot atau dapat juga digunakan uji Jarque-Bera (JB). Pada pendekatan $Q-Q$ plot, jika titik-titik (dots) menyebar jauh (menyebar berliku-liku pada garis diagonal seperti ular) dari garis diagonal, maka diindikasi asumsi normalitas error tidak dipenuhi. Jika titik-titik menyebar sangat dekat pada garis diagonal, maka asumsi normalitas dipenuhi.

Dalam pendekatan uji Jarque-Bera, pengujian normalitas dilakukan dengan menggunakan data residual $(\hat{e})$. Hipotesis nol menyatakan error berdistribusi normal, sedangkan hipotesis alternatif menyatakan error tidak berdistribusi normal. Untuk pengambilan keputusan terhadap hipotesis, dapat dibandingkan antara nilai probabilitas dari uji Jarque-Bera dan tingkat signifikansi yang digunakan $(\alpha)$. Berikut aturan pengambilan keputusan terhadap hipotesis.

Jika nilai probabilitas $\geq \alpha, H_{0}$ diterima dan $H_{1}$ ditolak. Jika nilai probabilitas $<\alpha, H_{0}$ ditolak dan $H_{1}$ diterima.

Gambar 2.4 menunjukkan nilai probabilitas dari uji Jarque-Bera. Diketahui nilai probabilitas (Probability) dari uji Jarque-Bera adalah 0,739403.

\section{Gambar 2.4}

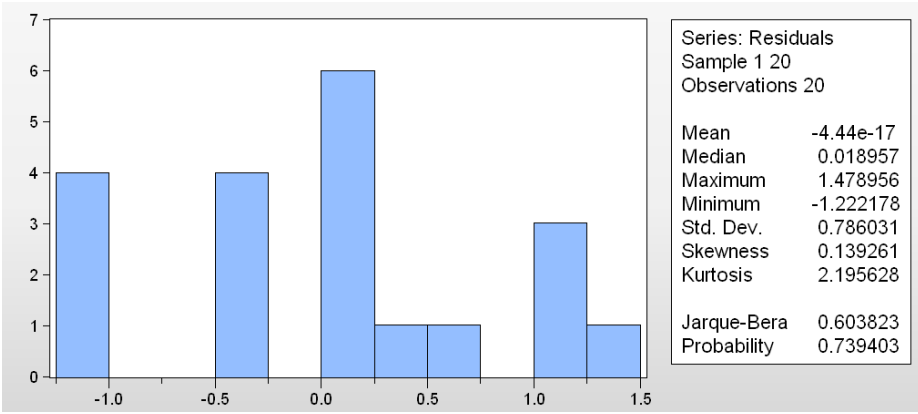


Pengambilan keputusan terhadap hipotesis, juga dapat dilakukan dengan membandingkan nilai statisik dari uji Jarque-Bera terhadap nilai kritis chikuadrat $\chi_{\text {kritis }}^{2}$ (atau chi-kuadrat tabel). Statistik dari uji Jarque-Bera berdistribusi sampling chi-kuadrat dengan derajat bebas 2 untuk ukuran sampel yang besar. Gujarati (2003:148) menyatakan sebagai berikut.

"Under the null hypothesis that the residuals are normally distributed, Jarque and Bera showed that asymptotically (i.e., in large samples) the JB statistic given in (5.12.1) follows the chi-square distribution with $2 d f$ '.

Berikut aturan pengambilan keputusan terhadap hipotesis.

Jika nilai statistik $J B \leq \chi_{\text {kritis }}^{2}, H_{0}$ diterima dan $H_{1}$ ditolak. Jika nilai statistik $J B>\chi_{\text {kritis }}^{2}, H_{0}$ ditolak dan $H_{1}$ diterima.

Berdasarkan Gambar 2.4, diketahui nilai statistik dari uji Jarque-Bera adalah 0,603823 .

\section{Multíkolinearitas}

Multikolinearitas merupakan suatu kejadian di mana terjadi korelasi atau hubungan linear yang kuat di antara variabel-variabel bebas. Salah satu asumsi yang dikenakan pada penggunaan regresi linear berganda adalah asumsi tidak terjadi multikolinearitas. Multikolinearitas dapat membuat beberapa permasalahan, yakni koefisien-koefisien regresi tidak dapat diestimasi secara tepat, serta tanda dari koefisien regresi dapat berubah dari sampel ke sampel. Apabila terjadi multikolinearitas sempurna (perfect multicolinearity), maka koefisien-koefisien regresi tidak dapat ditentukan (indeterminate), serta nilai standard error dari koefisien-koefisien regresi tidak terhingga (infinite). Jika terjadi multikolinearitas kuat (tidak sempurna), maka koefisien-koefisien regresi dapat ditentukan (determinate), namun memiliki standard error yang besar, sehingga mengakibatkan koefisien-koefisien regresi tidak diestimasi dengan tingkat ketelitian yang akurat. Perhatikan data pada Tabel 2.4.

\section{Tabel 2.4}

\begin{tabular}{|c|c|c|c|c|c|c|c|c|}
\hline$Y$ & 1 & 2 & 4 & 5 & 6 & 8 & 10 & 12 \\
\hline$X_{1}$ & 1 & 2 & 3 & 4 & 5 & 6 & 7 & 8 \\
\hline$X_{2}$ & 3 & 5 & 7 & 9 & 11 & 13 & 15 & 17 \\
\hline
\end{tabular}

Berdasarkan data pada Tabel 2.4, misalkan $Y$ merupakan variabel tak bebas, sedangkan $X_{1}$ dan $X_{2}$ merupakan variabel bebas. Perhatikan bahwa terjadi korelasi atau hubungan linear yang sempurna antara variabel bebas $X_{1}$ dan variabel bebas $X_{2}$, yakni dapat dinyatakan dalam bentuk persamaan linear $X_{2}=$ 
$2 X_{1}+1$. Jika dihitung nilai korelasi antara variabel bebas $X_{1}$ dan variabel bebas $X_{2}$, maka diperoleh nilai korelasi sebesar 1 , yang berarti terjadi korelasi linear yang sempurna antara variabel bebas $X_{1}$ dan variabel bebas $X_{2}$. Salah satu akibat dari terjadinya hubungan linear yang sempurna di antara variabelvariabel bebas adalah koefisien-koefisien regresi tidak dapat ditentukan nilainya, serta standard error dari koefisien-koefisien regresi bernilai tak terhingga (infinite). Persamaan regresi linear berganda untuk data pada Tabel 2.4 adalah sebagai berikut.

$$
\hat{Y}=\hat{\alpha}+\hat{\beta}_{1} X_{1}+\hat{\beta}_{2} X_{2}[2.1]
$$

Berikut akan dihitung nilai dari koefisien regresi $\hat{\beta}_{1}$ dan $\hat{\beta}_{2}$ untuk data pada Tabel 2.4.

Tabel 2.5

\begin{tabular}{|c|c|c|c|c|c|c|c|c|c|}
\hline & & & & & & & & & Total \\
\hline$Y$ & 1 & 2 & 4 & 5 & 6 & 8 & 10 & 12 & 48 \\
\hline$X_{1}$ & 1 & 2 & 3 & 4 & 5 & 6 & 7 & 8 & 36 \\
\hline$X_{2}$ & 3 & 5 & 7 & 9 & 11 & 13 & 15 & 17 & 80 \\
\hline$X_{1} Y$ & 1 & 4 & 12 & 20 & 30 & 48 & 70 & 96 & 281 \\
\hline$X_{2} Y$ & 3 & 10 & 28 & 45 & 66 & 104 & 150 & 204 & 610 \\
\hline$X_{1} X_{2}$ & 3 & 10 & 21 & 36 & 55 & 78 & 105 & 136 & 444 \\
\hline$X_{1}^{2}$ & 1 & 4 & 9 & 16 & 25 & 36 & 49 & 64 & 204 \\
\hline$X_{2}^{2}$ & 9 & 25 & 49 & 81 & 121 & 169 & 225 & 289 & 968 \\
\hline$Y^{2}$ & 1 & 4 & 16 & 25 & 36 & 64 & 100 & 144 & 390 \\
\hline
\end{tabular}

$$
\begin{gathered}
p=n \sum X_{1} Y-\sum X_{1} \sum Y=(8)(281)-(36)(48)=520 \\
q=n \sum X_{2}^{2}-\left(\sum X_{2}\right)^{2}=(8)(968)-(80)^{2}=1344 \\
r=n \sum X_{1} X_{2}-\sum X_{1} \sum X_{2}=(8)(444)-(36)(80)=672 \\
s=n \sum X_{2} Y-\sum X_{2} \sum Y=(8)(610)-(80)(48)=1040 \\
t=n \sum X_{1}^{2}-\left(\sum X_{1}\right)^{2}=(8)(204)-(36)^{2}=336 \\
u=t q-r^{2}=0 .
\end{gathered}
$$


Sehingga nilai $\hat{\beta}_{1}$ dan $\hat{\beta}_{2}$ adalah

$$
\begin{aligned}
& \hat{\beta}_{1}=\frac{p q-r s}{u}=\frac{(520)(1344)-(672)(1040)}{0}=\frac{0}{0} \\
& \hat{\beta}_{2}=\frac{s t-p r}{u}=\frac{(1040)(336)-(520)(672)}{0}=\frac{0}{0} .
\end{aligned}
$$

Perhatikan bahwa koefisien regresi $\hat{\beta}_{1}$ dan $\hat{\beta}_{2}$ berdasarkan perhitungan di atas tidak dapat ditentukan. Hal ini disebabkan karena terjadi hubungan linear yang sempurna antara variabel bebas $X_{1}$ dan variabel bebas $X_{2}$. Berikut akan dihitung standard error dari koefisien regresi $\hat{\beta}_{1}$ dan $\hat{\beta}_{2}$.

Tabel 2.6

\begin{tabular}{|c|c|c|c|c|c|c|c|c|c|}
\cline { 5 - 10 } & & & & & & & & & \\
\hline$\left(X_{1}-\bar{X}_{1}\right)^{2}$ & 12,25 & 6,25 & 2,25 & 0,25 & 0,25 & 2,25 & 6,25 & 12,25 & 42 \\
\hline$\left(X_{2}-\bar{X}_{2}\right)^{2}$ & 49 & 25 & 9 & 1 & 1 & 9 & 25 & 49 & 168 \\
\hline$\left(X_{1}-\bar{X}_{1}\right)\left(X_{2}-\bar{X}_{2}\right)$ & 24,5 & 12,5 & 4,5 & 0,5 & 0,5 & 4,5 & 12,5 & 24,5 & 84 \\
\hline
\end{tabular}

$$
\begin{aligned}
& s_{\widehat{\beta}_{1}}=\frac{s \quad \sqrt{\sum\left(X_{2}-\bar{X}_{2}\right)^{2}}}{\left[\sqrt{\left(\sum\left(X_{1}-\bar{X}_{1}\right)^{2}\right)\left(\sum\left(X_{2}-\bar{X}_{2}\right)^{2}\right)-\left(\sum\left(X_{1}-\bar{X}_{1}\right)\left(X_{2}-\bar{X}_{2}\right)\right)^{2}}\right]} \\
& s_{\widehat{\beta}_{1}}=\frac{s \quad \sqrt{\sum\left(X_{2}-\bar{X}_{2}\right)^{2}}}{\left[\sqrt{(42)(168)-(84)^{2}}\right]} \\
& s_{\widehat{\beta}_{1}}=\frac{s \quad \sqrt{\sum\left(X_{2}-\bar{X}_{2}\right)^{2}}}{0}=\infty \\
& s_{\widehat{\beta}_{2}}=\frac{s \quad \sqrt{\sum\left(X_{1}-\bar{X}_{1}\right)^{2}}}{\left[\sqrt{\left(\sum\left(X_{1}-\bar{X}_{1}\right)^{2}\right)\left(\sum\left(X_{2}-\bar{X}_{2}\right)^{2}\right)-\left(\sum\left(X_{1}-\bar{X}_{1}\right)\left(X_{2}-\bar{X}_{2}\right)\right)^{2}}\right]} \\
& s_{\widehat{\beta}_{2}}=\frac{s \quad \sqrt{\sum\left(X_{1}-\bar{X}_{1}\right)^{2}}}{\left[\sqrt{(42)(168)-(84)^{2}}\right]} \\
& s_{\widehat{\beta}_{2}}=\frac{s \quad \sqrt{\sum\left(X_{1}-\bar{X}_{1}\right)^{2}}}{0}=\infty \text {. }
\end{aligned}
$$


Perhatikan bahwa nilai standard error dari koefisien regresi $\hat{\beta}_{1}$ dan $\hat{\beta}_{2}$ adalah tak terhingga (infinite). Hal ini berarti tingkat ketelitian dalam memperkirakan parameter koefisien regresi sangat buruk. Interval keyakinan (confidence interval) dalam memperkirakan koefisien regresi populasi sangat lebar.

Untuk mendeteksi apakah terindikasi terjadi gejala multikolinearitas, dapat digunakan pendekatan matriks korelasi dari variabel bebas. Jika terdapat nilai korelasi di atas 0,8 antar variabel bebas, maka diindikasi terjadi multikolinearitas. Gujarati (2003:359) menyatakan sebagai berikut.

"Another suggested rule of thumb is that if the pair-wise or zero-order correlation coefficient between two regressors is high, say, in excess of 0,8 , then multicolinearity is a serious problem".

\section{Asumsi Non-Autokorelasí}

Selain asumsi normalitas dari error dan tidak terjadi multikolinearitas, asumsi lain yang dikenakan pada penggunaan regresi linear berganda adalah asumsi independensi dari error (independent errors). Stevens (2009:90) menyatakan sebagai berikut.

"Recal that in linear regression model, it is assumed that the errors are independent and follow a normal distribution with constant variance".

Senada dengan Stevens, Field (2009:220) menyatakan sebagai berikut.

"Independent errors: For any two observations the residual terms should be uncorrelated (or independent). This eventually is sometimes described as a lack of autocorrelation".

Asumsi ini disebut juga dengan asumsi non-autokorelasi (non-autocorrelation). Untuk menguji asumsi independensi dari error, dapat digunakan uji DurbinWatson. Nilai statistik dari uji Durbin-Watson berkisar di antara 0 dan 4. Field (2009:220) menyatakan sebagai berikut.

"Specifically, it (Durbin-Watson) tests whether adjacent residuals are correlated. The test statistic can vary between 0 dan 4 with a value 2 meaning that the residuals are uncorrelated".

Nilai statistik dari uji Durbin-Watson yang lebih kecil dari 1 atau lebih besar dari 3 diindikasi terjadi autokorelasi. Field (2009:220-221) menyatakan sebagai berikut.

"The size of the Durbin-Watson statistic depends upon the number of predictors in the model and the number of observations. For accuracy, you should look up the exact acceptable values in Durbin and Watson's (1951) 
original paper. As very conservative rule of thumb, values less then 1 or greater than 3 are definitely cause for concern; however, values closer to 2 may stil be problematic depending on your sample and model".

Gujarati (2003:489) mengemukakan dalam keadaan pelanggaran asumsi independensi dari error, estimator-estimator yang dihasilkan dengan metode kuadrat terkecil (ordinary least square) masih bersifat tak bias, konsisten, secara asismtotik terdistribusi normal, namun estimator-estimator tersebut tidak lagi efisien. Sebagai akibatnya, uji signifikansi $t$ dan $F$ yang biasa tidak lagi valid.

\section{Asumsi Homoskedastísitas}

Asumsi homoskedastisitas menyatakan terjadi kesamaan varians dari error (errors with constant variance) untuk setiap tingkatan atau level dari variabelvariabel bebas. Ketika asumsi homoskedastisitas tidak dipenuhi, maka peristiwa tersebut disebut heteroskedastisitas. Untuk mendeteksi terjadinya gejala heteroskedastisitas dapat dilakukan dengan menggunakan uji Park. Berikut langkah-langkah untuk melakukan uji asumsi homoskedastisitas dengan menggunakan uji Park.

$\Rightarrow$ Tentukan persamaan regresi dari variabel tak bebas berdasarkan variabel-variabel bebas. Misalkan $Y$ sebagai variabel tak bebas, sedangkan $X_{1}$ dan $X_{2}$ merupakan variabel bebas.

$\Rightarrow$ Setelah diperoleh persamaan regresi, yakni $\hat{Y}=\hat{\alpha}+\hat{\beta}_{1} X_{1}+\hat{\beta}_{2} X_{2}$, hitung nilai residual, yakni selisih antara variabel tak bebas dan estimasi dari variabel tak bebas $(\hat{e}=Y-\hat{Y})$.

$\Rightarrow$ Kuadratkan untuk tiap-tiap nilai residual $\left(\hat{e}^{2}\right)$.

$\Rightarrow$ Hitung logaritma natural $(\ln )$ untuk kuadrat residual dan variabel bebas $X_{1}$ dan $X_{2}$, sehingga diperoleh $\ln \left(\hat{e}^{2}\right), \ln \left(X_{1}\right)$, dan $\ln \left(X_{2}\right)$.

$\Rightarrow$ Lakukan regresi dari logaritma natural kuadrat residual terhadap logaritma natural dari variabel-variabel bebas. Dalam hal ini, lakukan regresi $\ln \left(\hat{e}^{2}\right)$ terhadap $\ln \left(X_{1}\right)$ dan $\ln \left(X_{2}\right)$, sehingga diperoleh persamaan regresi sebagai berikut.

$$
\widehat{\ln \left(\hat{e}^{2}\right)}=a+b_{1} \ln X_{1}+b_{2} \ln X_{2} \quad[2.2]
$$

$\Rightarrow$ Jika terdapat koefisien regresi $b$ yang signifikan secara statistik (statistically significant), maka diindikasi terjadi heteroskedastisitas. Namun jika tidak terdapat koefisien regresi $b$ yang signifikan secara 
statistik (statistically significant), maka asumsi homoskedastisitas dipenuhi (Gujarati, 2003:404).

Selain uji Park, dapat juga digunakan uji Glejser. Berikut langkah-langkah untuk melakukan uji asumsi homoskedastisitas dengan menggunakan uji Glejser.

$\Rightarrow$ Tentukan persamaan regresi dari variabel tak bebas berdasarkan variabel-variabel bebas. Misalkan $Y$ sebagai variabel tak bebas, sedangkan $X_{1}$ dan $X_{2}$ merupakan variabel bebas.

$\Rightarrow$ Setelah diperoleh persamaan regresi, yakni $\hat{Y}=\hat{\alpha}+\hat{\beta}_{1} X_{1}+\hat{\beta}_{2} X_{2}$, hitung nilai residual, yakni selisih antara variabel tak bebas dan estimasi dari variabel tak bebas $(\hat{e}=Y-\hat{Y})$.

$\Rightarrow$ Absolutkan untuk tiap-tiap nilai residual $(|\hat{e}|)$.

$\Rightarrow$ Lakukan regresi dari $|\hat{e}|$ terhadap $X_{1}$ dan $X_{2}$, sehingga diperoleh persamaan regresi sebagai berikut.

$$
\widehat{\mid \hat{e}} \mid=a+b_{1} X_{1}+b_{2} X_{2} \quad[2.3]
$$

$\Rightarrow$ Jika terdapat koefisien regresi $b$ yang signifikan secara statistik, maka diindikasi terjadi heteroskedastisitas. Namun jika tidak terdapat koefisien regresi $b$ yang signifikan secara statistik, maka asumsi homoskedastisitas dipenuhi (Gujarati, 2003:406).

Selain uji Park dan uji Glejser, dapat juga digunakan uji White. Berikut langkah-langkah untuk melakukan uji asumsi homoskedastisitas dengan menggunakan uji White.

$\Rightarrow$ Tentukan persamaan regresi dari variabel tak bebas berdasarkan variabel-variabel bebas. Misalkan $Y$ sebagai variabel tak bebas, sedangkan $X_{1}$ dan $X_{2}$ merupakan variabel bebas.

$\Rightarrow$ Setelah diperoleh persamaan regresi, yakni $\hat{Y}=\hat{\alpha}+\hat{\beta}_{1} X_{1}+\hat{\beta}_{2} X_{2}$, hitung nilai residual, yakni selisih antara variabel tak bebas dan estimasi dari variabel tak bebas $(\hat{e}=Y-\hat{Y})$.

$\Rightarrow$ Kuadratkan untuk tiap-tiap nilai residual $\left(\hat{e}^{2}\right)$.

$\Rightarrow$ Peroleh pesamaan regresi sebagai berikut.

$$
\widehat{\hat{e}^{2}}=a+b_{1} X_{1}+b_{2} X_{2}+b_{3} X_{1}^{2}+b_{4} X_{2}^{2}+b_{5} X_{1} X_{2}
$$


$\Rightarrow$ Peroleh nilai koefisien determinasi $\left(r^{2}\right)$ dari persamaan regresi [2.4]. Gujarati (2003:413) mengemukakan bahwa dengan hipotesis nol menyatakan tidak terjadi heteroskedastisitas, serta nilai perkalian antara jumlah elemen sampel (sample size) dan $r^{2}$ pada persamaan regresi [2.4] secara asimtotis mengikuti distribusi chi-kuadrat dengan derajat bebas merupakan jumlah regressors (tidak termasuk konstanta) pada persamaan regresi [2.4]. Berdasarkan persamaan regresi [2.4], diketahui nilai derajat bebas adalah 5 .

$\Rightarrow$ Jika nilai dari hasil perkalian antara jumlah elemen sampel (sample size) dan $r^{2}$ pada persamaan regresi [2.4] lebih besar dari nilai kritis chi-kuadrat, maka disimpulkan terjadi heteroskedastisitas (Gujarati, 2003:413)

Misalkan diberikan data populasi sebagai berikut.

Tabel 2.7

\begin{tabular}{|l|l|l|l|l|l|l|l|l|l|l|l|l|l|l|l|}
\hline$X$ & 1 & 1 & 1 & 2 & 2 & 2 & 3 & 3 & 3 & 4 & 4 & 4 & 5 & 5 & 5 \\
\hline$Y$ & 1 & 2 & 3 & 2 & 3 & 4 & 3 & 4 & 5 & 4 & 5 & 6 & 5 & 6 & 7 \\
\hline
\end{tabular}

Berdasarkan data pada Tabel 2.7, misalkan $X$ adalah variabel bebas, sedangkan $Y$ adalah variabel tak bebas. Berikut disajikan dalam grafik berdasarkan data pada Tabel 2.7 (Gambar 2.5).

\section{Gambar 2.5}

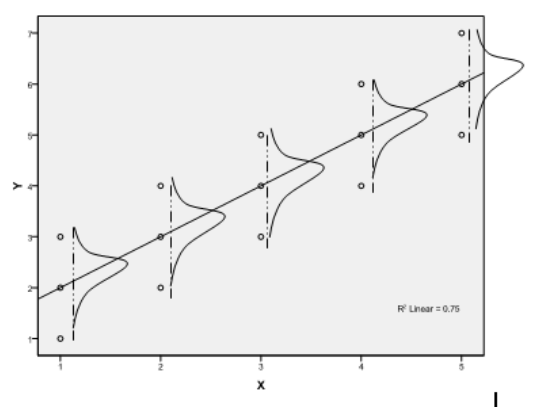

Berikut akan dihitung nilai varians $Y$ untuk masing-masing nilai $X$.

$\Rightarrow$ Menghitung varians $Y$ untuk $X=1$. 


$$
\operatorname{Var}(Y / X=1)=\frac{(1-2)^{2}+(2-2)^{2}+(3-2)^{2}}{3}=\frac{2}{3}=0,667
$$

$\Rightarrow \quad$ Menghitung varians $Y$ untuk $X=2$.

$$
\operatorname{Var}(Y / X=2)=\frac{(2-3)^{2}+(3-3)^{2}+(4-3)^{2}}{3}=\frac{2}{3}=0,667
$$

$\Rightarrow \quad$ Menghitung varians $Y$ untuk $X=3$.

$$
\operatorname{Var}(Y / X=3)=\frac{(3-4)^{2}+(4-4)^{2}+(5-4)^{2}}{3}=\frac{2}{3}=0,667
$$

$\Rightarrow$ Menghitung varians $Y$ untuk $X=4$.

$$
\operatorname{Var}(Y / X=4)=\frac{(4-5)^{2}+(5-5)^{2}+(6-5)^{2}}{3}=\frac{2}{3}=0,667
$$

$\Rightarrow \quad$ Menghitung varians $Y$ untuk $X=5$.

$$
\operatorname{Var}(Y / X=5)=\frac{(5-6)^{2}+(6-6)^{2}+(7-6)^{2}}{3}=\frac{2}{3}=0,667
$$

Perhatikan bahwa nilai varians dari $Y$ untuk setiap $X$ bersifat konstan atau dapat dinyatakan $\operatorname{Var}\left(Y_{i}\right)=\operatorname{Var}\left(e_{i}\right)=\sigma^{2}$ untuk setiap $i=1,2,3, \ldots, n$. Fenomena ini disebut dengan istilah homoskedastisitas.

\section{Gambar 2.6}

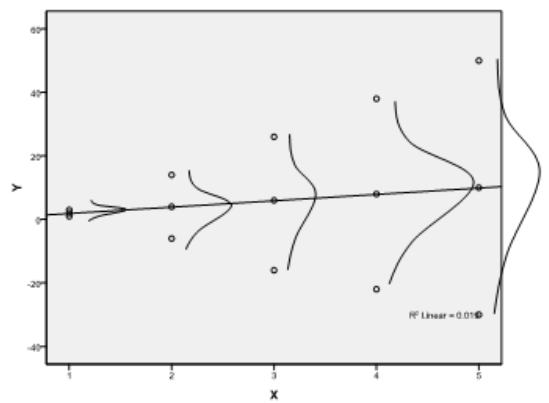

Pada Gambar 2.6 memperlihatkan varians dari $Y$ untuk setiap $X$. Nilai-nilai varians tersebut berbeda-beda atau dapat dinyatakan dengan $\operatorname{Var}\left(Y_{i}\right)=$ $\operatorname{Var}\left(e_{i}\right)=\sigma_{i}^{2}$. Fenomena ini disebut dengan istilah heteroskedastisitas. 


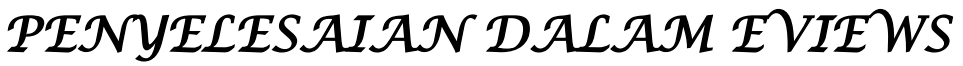

Andaikan diberikan data mengenai pengeluaran per-bulan, pendapatan perbulan, dan jumlah anak, dari 20 keluarga (Tabel 2.1).

Tabel 2.1 Data Mengenai Pengeluaran Per-Bulan, Pendapatan Per-Bulan, dan Jumlah Anak dari 20 Keluarga (Data Fiktif)

\begin{tabular}{|c|c|c|c|}
\hline Keluarga Ke & $\begin{array}{l}\text { Pengeluaran } \\
\text { (dalam juta) }\end{array}$ & $\begin{array}{l}\text { Pendapatan } \\
\text { (dalam juta) }\end{array}$ & Jumlah Anak \\
\hline 1 & 3.3 & 3.6 & 4 \\
\hline 2 & 4.2 & 4.7 & 2 \\
\hline 3 & 5.4 & 6.5 & 5 \\
\hline 4 & 5.3 & 8.4 & 3 \\
\hline 5 & 5.7 & 6.2 & 5 \\
\hline 6 & 3.5 & 4.5 & 2 \\
\hline 7 & 6.2 & 7.8 & 5 \\
\hline 8 & 3.6 & 3.9 & 2 \\
\hline 9 & 7.5 & 8.9 & 5 \\
\hline 10 & 5.4 & 6.2 & 2 \\
\hline 11 & 5.3 & 8.5 & 5 \\
\hline 12 & 4.3 & 5 & 3 \\
\hline 13 & 7.8 & 8 & 6 \\
\hline 14 & 4.2 & 6.4 & 3 \\
\hline 15 & 3.5 & 4 & 3 \\
\hline 16 & 5.3 & 8.9 & 5 \\
\hline 17 & 4.3 & 10 & 3 \\
\hline 18 & 7.8 & 8 & 6 \\
\hline 19 & 4.2 & 5 & 3 \\
\hline 20 & 3.5 & 4 & 3 \\
\hline
\end{tabular}

Berdasarkan data pada Tabel 2.1, diketahui pada keluarga ke-1 memiliki pendapatan per-bulan sebesar 3,6 juta, 4 orang anak, dan pengeluaran per-bulan sebesar 3,3 juta. Keluarga ke-19 memiliki pendapatan per-bulan sebesar 5 juta, 3 orang anak, dan pengeluaran per-bulan sebesar 4.2 juta. Misalkan variabel pengeluaran sebagai variabel tak bebas (dependent), sedangkan variabel 
pendapatan dan jumlah anak sebagai variabel bebas (independent). Berikut halhal yang ingin diketahui.

$\Rightarrow$ Membuat persamaan regresi linear berganda yang menerangkan hubungan pengeluaran terhadap pendapatan, dan jumlah anak.

$\Rightarrow$ Menentukan seberapa besar faktor pendapatan berkontribusi dalam hal naik/turunnya pengeluaran, dengan mengontrol pengaruh jumlah anak. Kemudian menentukan apakah kontribusi tersebut signifikan secara statistik.

$\Rightarrow$ Menentukan seberapa besar faktor jumlah anak berkontribusi dalam hal naik/turunnya pengeluaran, dengan mengontrol pengaruh pendapatan. Kemudian menentukan apakan kontribusi tersebut signifikan secara statistik.

$\Rightarrow$ Menentukan faktor yang memberikan kontribusi paling besar terhadap naik/turunnya pengeluaran.

Sajikan data pada Tabel 2.1 dalam Microsoft Excel sebagai berikut (Gambar 2.1).

\section{Gambar 2.1}

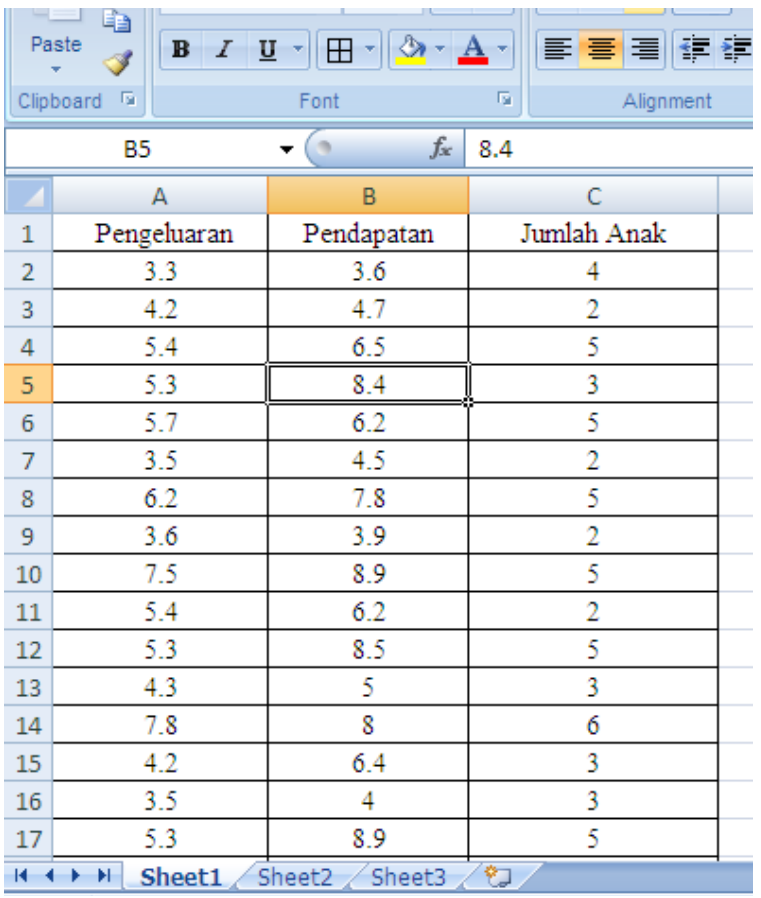




\begin{tabular}{|l|l|c|c|}
\hline 15 & 4.2 & 6.4 & 3 \\
\hline 16 & 3.5 & 4 & 3 \\
\hline 17 & 5.3 & 8.9 & 5 \\
\hline 18 & 4.3 & 10 & 3 \\
\hline 19 & 7.8 & 8 & 6 \\
\hline 20 & 4.2 & 5 & 3 \\
\hline 21 & 3.5 & 4 & 3 \\
\hline \hline
\end{tabular}

Selanjutnya simpan dengan format Excel 97-2003 Workbook dan ketik nama file dengan data regresi ugi (Gambar 2.2).

\section{Gambar 2.2}

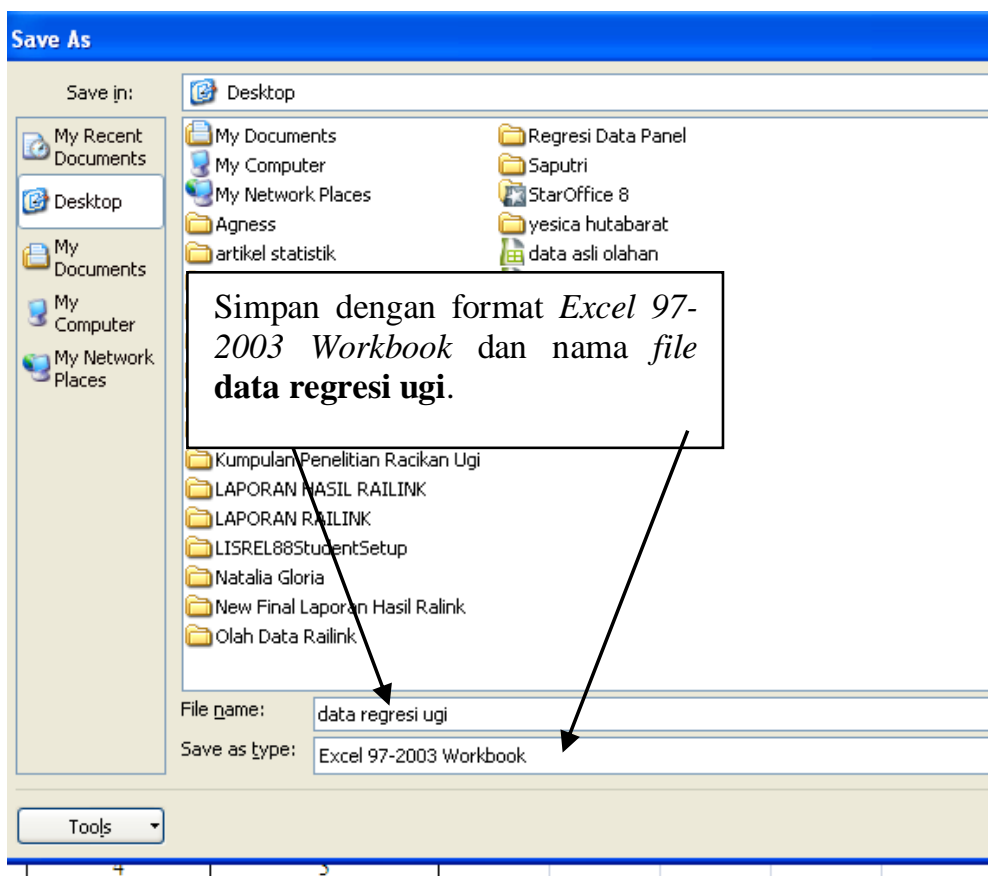

Kemudian disimpan (pilih Save), selanjutnya keluar dari program Microsoft Excel, dan aktifikan EViews 7. Pilih File $=>$ New $=>$ Workfile... (Gambar 2.3), sehingga muncul kotak Workfile Create (Gambar 2.4). 


\section{Gambar 2.3}

1. EViews
\begin{tabular}{|l|l|ll|}
\hline File Edit Object View Proc Quick Options Window & Help \\
\hline New & Ctrl+S & Darkfile... & Ctrl+N \\
\hline Open & Program & \\
Save & & Iext File \\
Save As... & & \\
\hline
\end{tabular}

\section{Gambar 2.4}

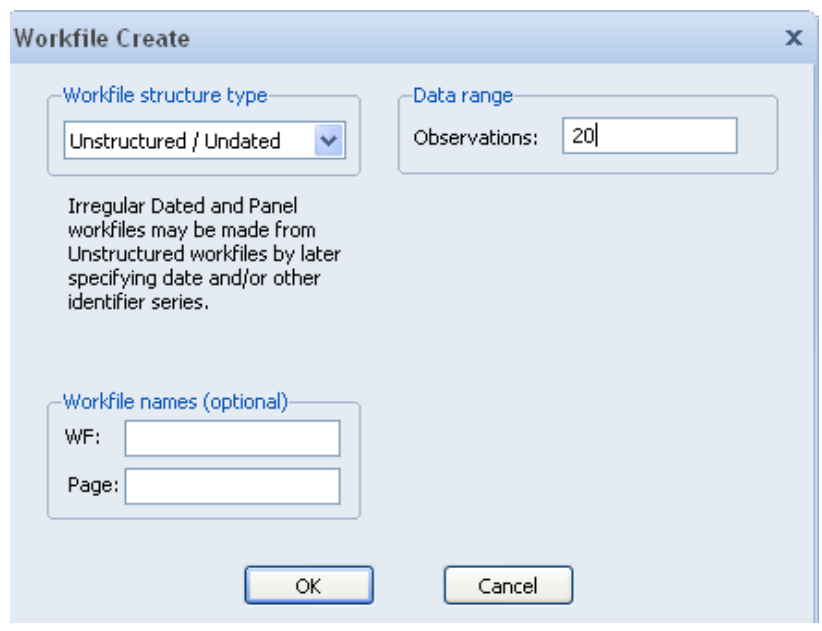

Pada Gambar 2.4, yakni pada Workfile structure type, atur menjadi Unstructured / Undated, dan pada Observations:, ketik 20. Dalam hal ini, jumlah keluarga yang diteliti sebanyak 20. Selanjutnya pilih OK, sehingga muncul kotakWorkfile: UNTITLED (Gambar 2.5).

\section{Gambar 2.5}

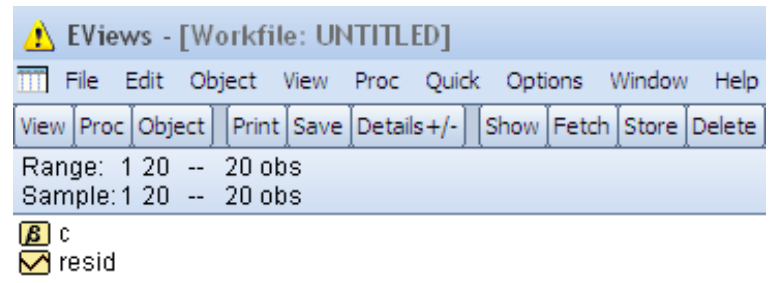




\section{Gambar 2.6}

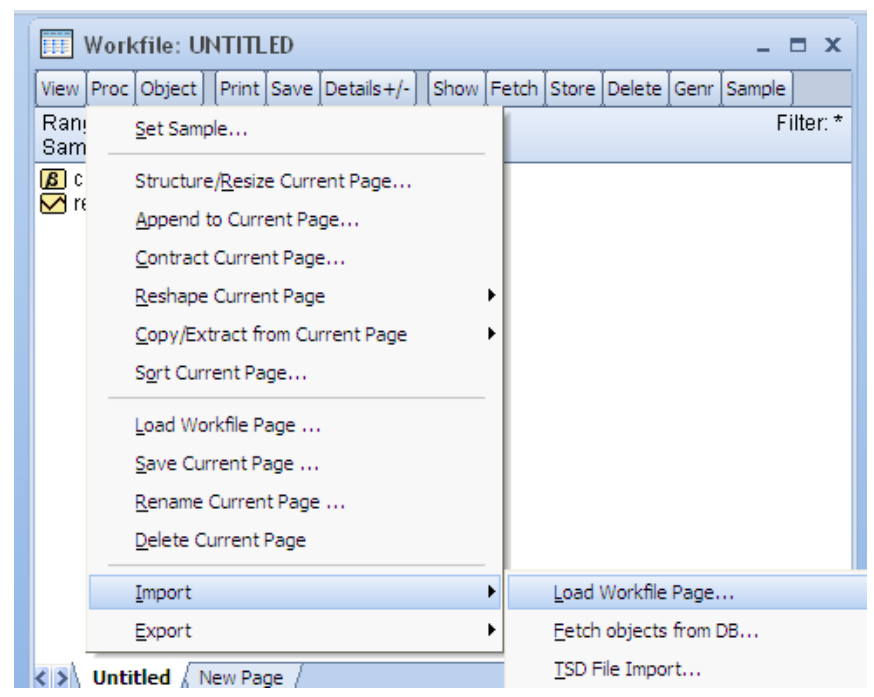

Pada Gambar 2.6, pilih Proc $\Rightarrow$ Import $\Rightarrow$ Load Workfile Page..., sehingga muncul kotak Open (Gambar 2.7). Pada Gambar 2.7, pilih file Microsoft Excel yang telah disimpan sebelumnya, yakni dengan nama data regresi ugi, dengan Files of type: Excel 97-2003 file (*.xls). Kemudian pilih Open, sehingga muncul kotak Excel 97-2003 Read-Step lof 3 (Gambar 2.8).

\section{Gambar 2.7}

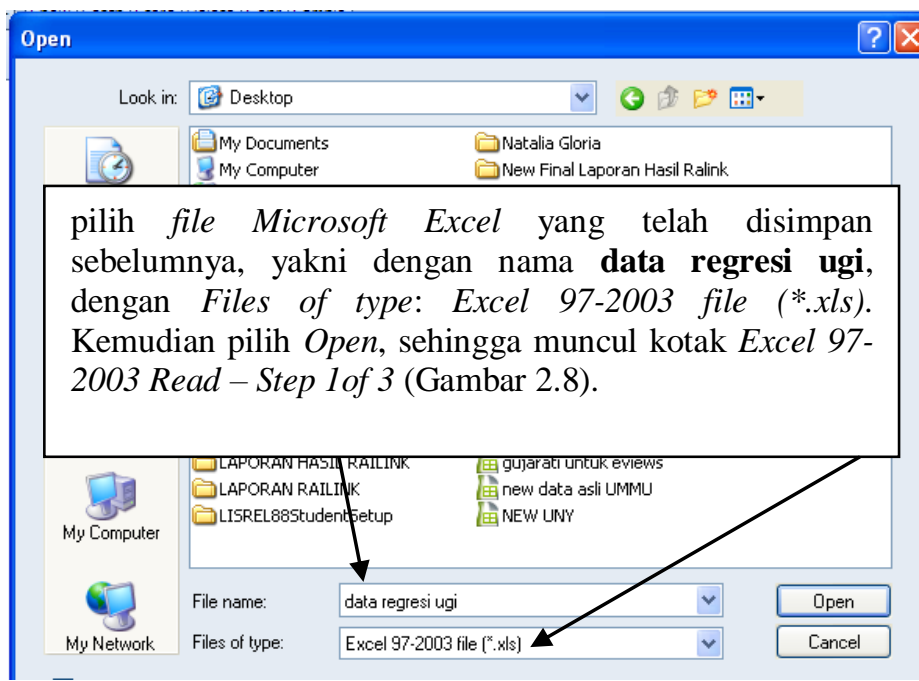


Pada Gambar 2.8, kemudian pilih Finish, sehingga muncul kotak seperti pada Gambar 2.9.

\section{Gambar 2.8}

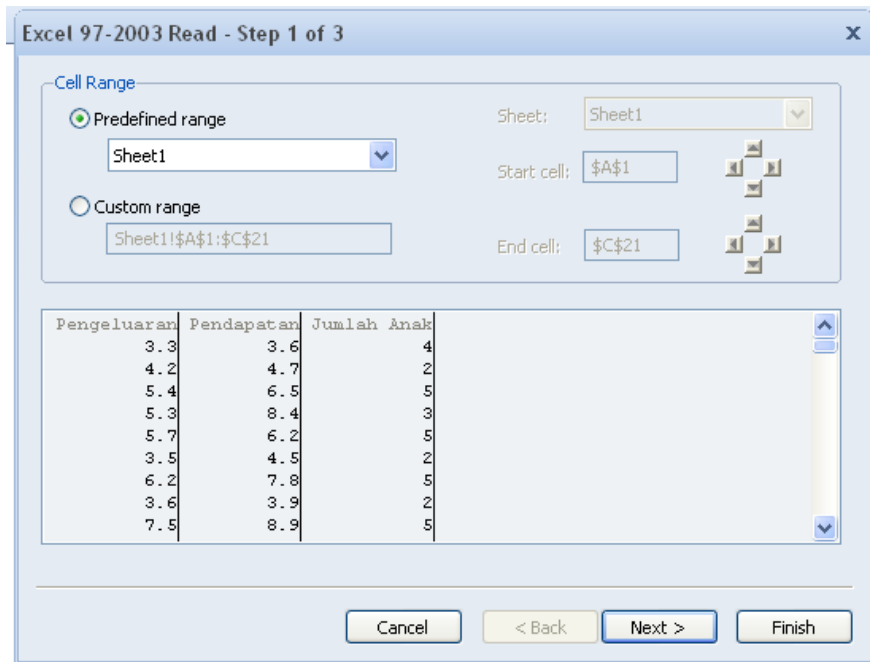

Gambar 2.9

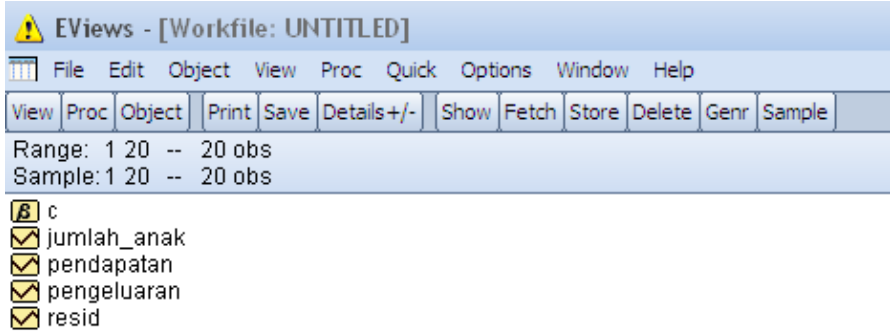

\section{Statistik Deskriptif}

Selanjutnya pilih Quick => Group Statistics $\Rightarrow$ Descriptive Statistics $\Rightarrow$ Common sample (Gambar 2.10), sehingga muncul kotak Series List (Gambar 2.11). 


\section{Gambar 2.10}

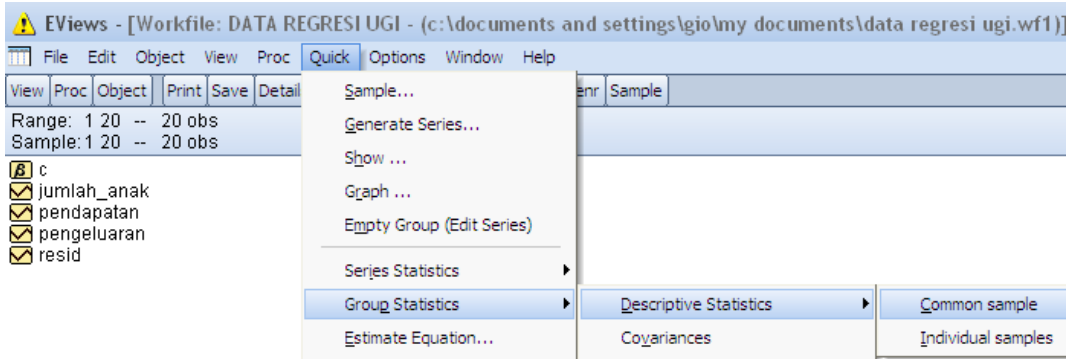

Pada kotak Series List (Gambar 2.11), ketik nama-nama variabel yang dilibatkan, yakni pendapatan, pengeluaran, dan jumlah_anak. Kemudian pilih OK, sehingga diperoleh hasil statistik deskriptif, seperti pada Gambar 2.12 .

\section{Gambar 11}

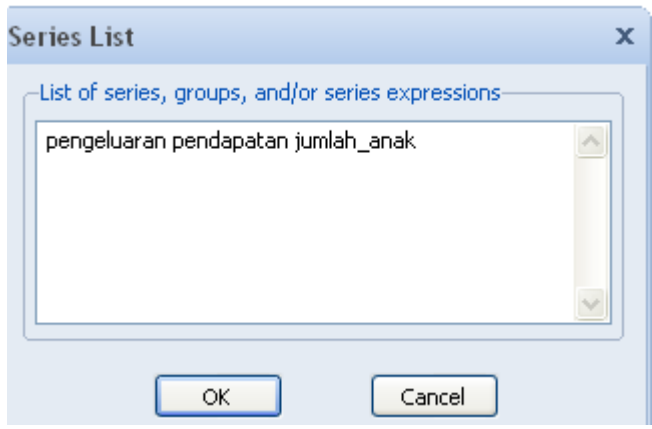

Gambar 12

\begin{tabular}{|c|c|c|c|c|c|c|c|}
\hline View & Proc Object & Print Name & Freeze & Sample & Sheet & Stats Spec & \\
\hline & & \multicolumn{5}{|c|}{ PENGELUA... PENDAPATAN JUMLAH_AN... } & \\
\hline \multicolumn{2}{|c|}{ Mean } & 5.015000 & \multicolumn{2}{|c|}{6.425000} & \multicolumn{2}{|r|}{3.750000} & \\
\hline \multicolumn{2}{|c|}{ Median } & 4.800000 & \multicolumn{2}{|c|}{6.300000} & \multicolumn{2}{|r|}{3.000000} & \\
\hline \multicolumn{2}{|c|}{ Maximum } & 7.800000 & \multicolumn{2}{|c|}{10.00000} & \multicolumn{2}{|r|}{6.000000} & \multirow{4}{*}{$\begin{array}{l}\text { Output statistik } \\
\text { deskriptif }\end{array}$} \\
\hline \multicolumn{2}{|c|}{ Minimum } & 3.300000 & \multicolumn{2}{|c|}{3.600000} & & 2.000000 & \\
\hline Std. D & Dev. & 1.431699 & & 013866 & & .371707 & \\
\hline Skew & vness & 0.736983 & & 117837 & & .211834 & \\
\hline \multicolumn{2}{|c|}{ Kurtosis } & 2.518769 & \multicolumn{2}{|c|}{1.658397} & \multicolumn{2}{|r|}{$1.653137 L$} & \\
\hline \multicolumn{2}{|c|}{ Jarque-Bera } & 2.003466 & \multicolumn{2}{|c|}{1.546202} & \multicolumn{2}{|r|}{1.661279} & \\
\hline \multicolumn{2}{|c|}{ Probability } & 0.367242 & \multicolumn{2}{|c|}{0.461580} & \multicolumn{2}{|r|}{0.435771} & \\
\hline \multicolumn{2}{|l|}{ Sum } & 100.3000 & \multicolumn{2}{|c|}{128.5000} & \multicolumn{2}{|r|}{75.00000} & \\
\hline \multicolumn{2}{|c|}{ Sum Sq. Dev. } & 38.94550 & \multicolumn{2}{|c|}{77.05750} & \multicolumn{2}{|r|}{35.75000} & \\
\hline \multicolumn{2}{|c|}{ Observations } & 20 & & 20 & & 20 & \\
\hline
\end{tabular}




\section{Estimasí Persamaan Regresi}

Selanjutnya pilih Quick $\Rightarrow$ Estimate Equation... (Gambar 2.13), sehingga muncul kotak Equation Estimation (Gambar 2.14).

\section{Gambar 2.13}

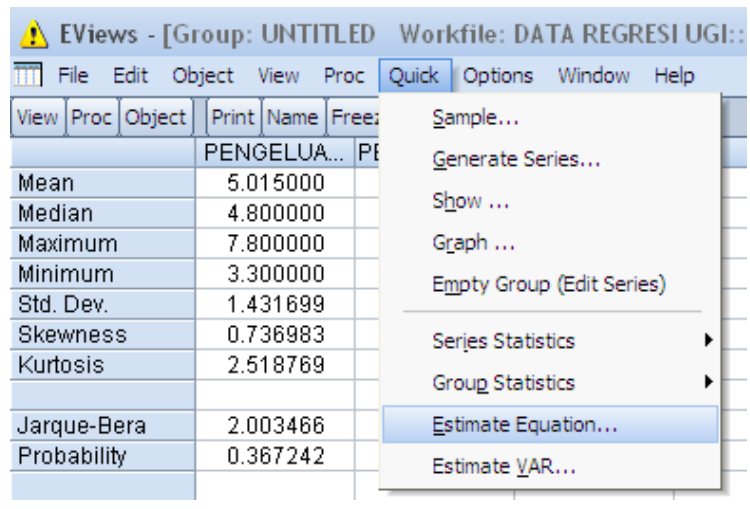

Gambar 2.14

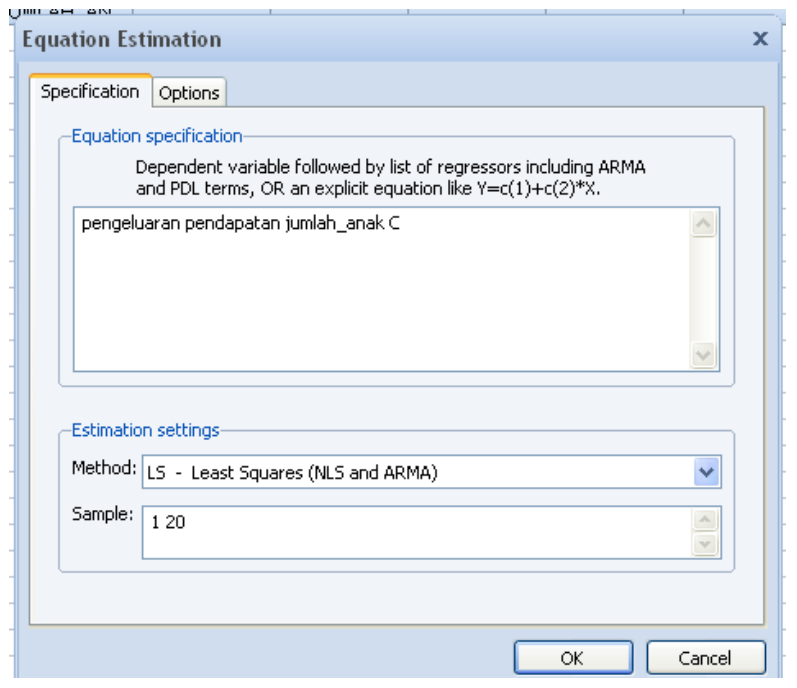

Pada Gambar 2.14, yakni Equation Estimation, ketik pengeluaran pendapatan jumlah_anak C, dan pilih OK. Hasilnya seperti pada Gambar 2.15. 


\section{Gambar 2.15}

!) EViews - [Equation: UNTITLED Workfile: DATA REGRESI UGI::Untitled
77 File Edit Object View Proc Quick Options Window Help
View Proc [Object] $[$ Print $[$ Name $[$ Freeze $]$ [Estimate $[$ Forecast $[$ Stats $[$ Resids $]$

Dependent Variable: PENGELUARAN

Method: Least Squares

Date: 04/22/15 Time: $20: 16$

Sample: 120

Included observations: 20

\begin{tabular}{lrlll}
\hline \hline \multicolumn{1}{c}{ Variable } & Coefficient & Std. Error & t-Statistic & Prob. \\
\hline \hline PENDAPATAN & 0.265841 & 0.114497 & 2.321809 & 0.0329 \\
JUMLAH_ANAK & 0.590938 & 0.168099 & 3.515419 & 0.0027 \\
C & 1.090953 & 0.671823 & 1.623868 & 0.1228 \\
\hline \hline R-squared & 0.698578 & Mean dependent var & 5.015000 \\
Adjusted R-squared & 0.663116 & S.D. dependent var & 1.431699 \\
S.E. of regression & 0.830983 & Akaike info criterion & 2.605066 \\
Sum squared resid & 11.73905 & Schwarz criterion & 2.754425 \\
Log likelihood & -23.05066 & Hannan-Quinn criter. & 2.634222 \\
F-statistic & 19.69963 & Durbin-Watson stat & 1.924282 \\
Prob(F-statistic) & 0.000037 & & &
\end{tabular}

\section{Uji Asumsi Normalitas dengan Ují Jarque-Bera}

Pilih View $=>$ Residual Diagnostics $=>$ Histogram - Normality Test (Gambar 2.16). Hasilnya seperti pada Gambar 2.17.

\section{Gambar 2.16}

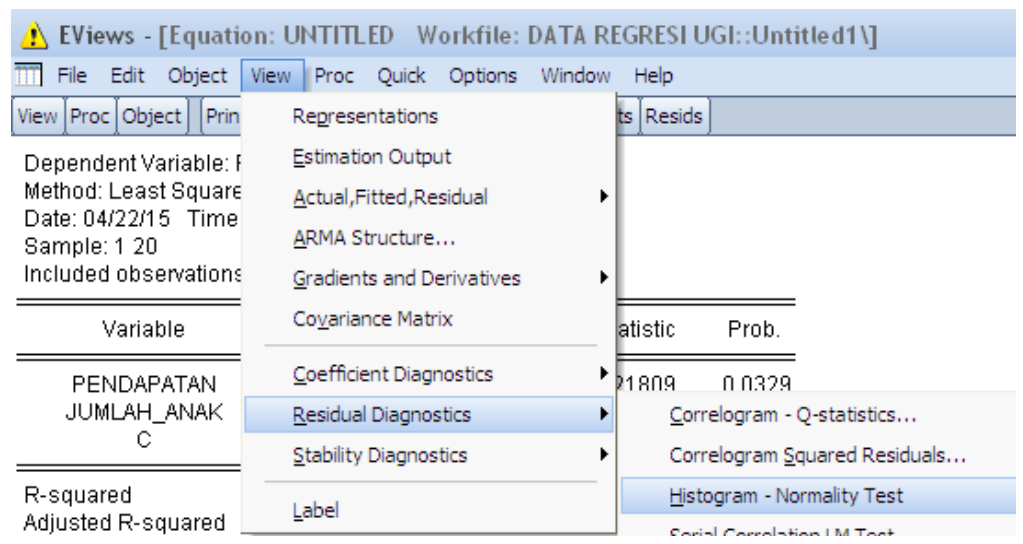


Gambar 2.17

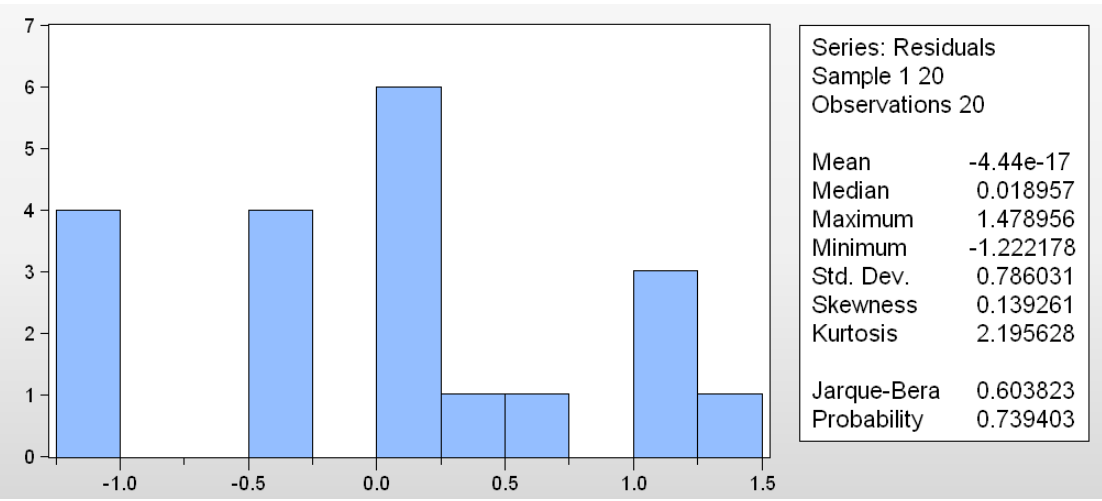

\section{Uji Asumsi Multikolinearitas}

Pilih Quick => Group Statistics => Correlations (Gambar 2.18), sehingga muncul kotak Series List (Gambar 2.19). Pada kotak Series List, ketik namanama variabel bebas, yakni pendapatan dan jumlah_anak. Kemudian pilih OK. Hasilnya seperti pada Gambar 2.20.

\section{Gambar 2.18}

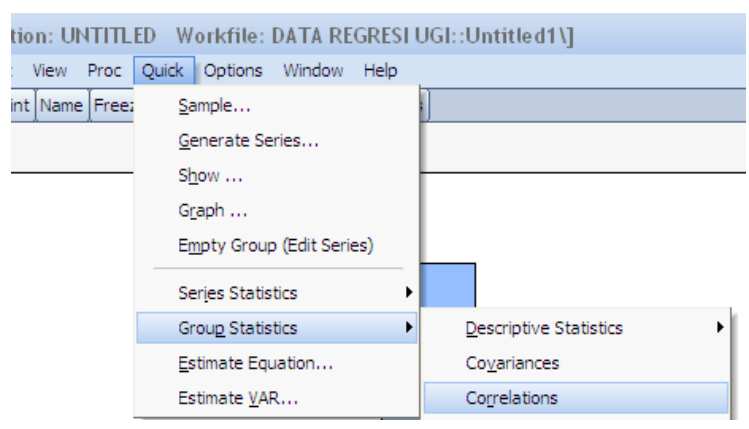

Gambar 2.19

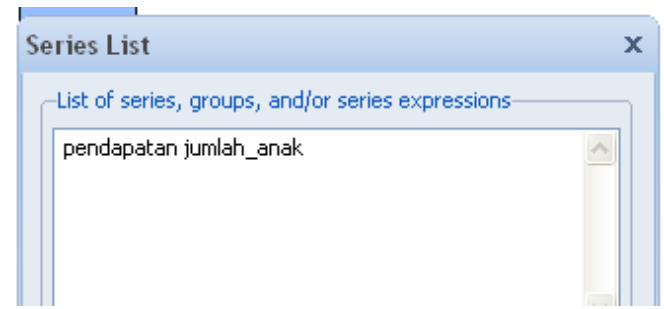




\section{Gambar 2.20}

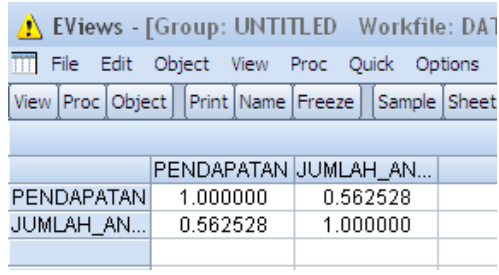

\section{Uji Asumsi Homoskedastisitas dengan Uji Glesjer, Uji White, dan Uji Park}

Pilih View $=>$ Residual Diagnostics $=>$ Heteroskedasticity Tests...(Gambar 2.22), sehingga muncul kotak Heteroskedasticity Tests (Gambar 2.23).

\section{Gambar 2.21}

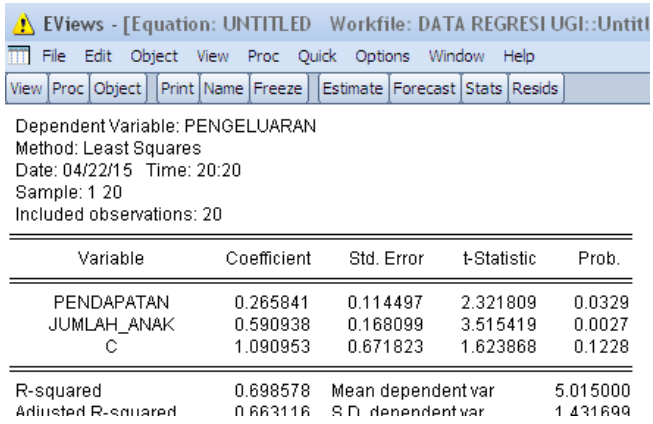

\section{Gambar 2.22}

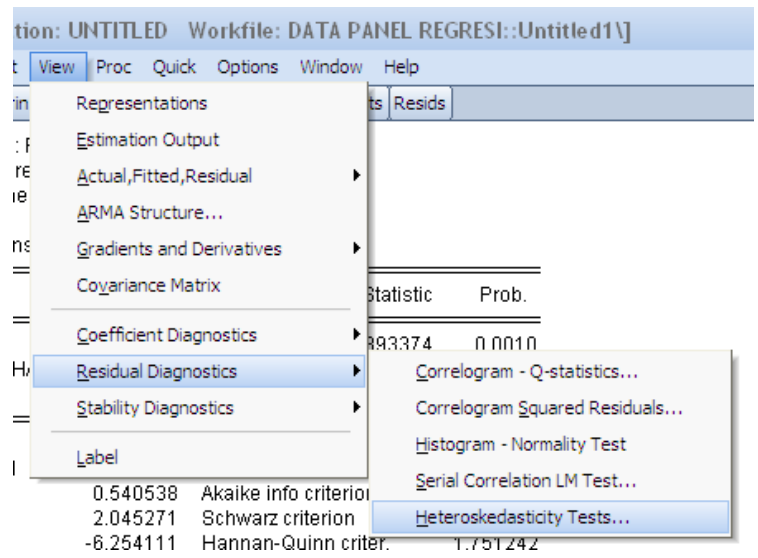




\section{Gambar 2.23}

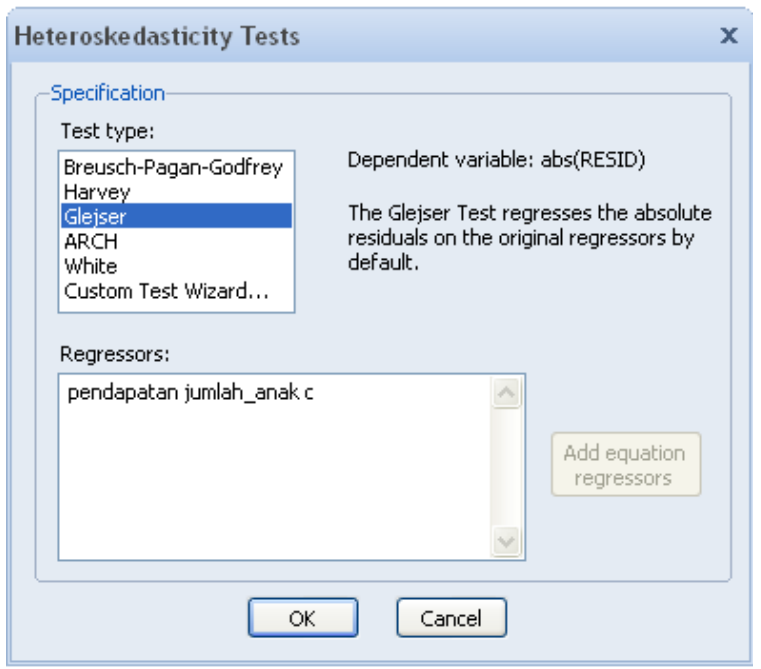

Pada Test type: pilih Glejser. Kemudian pilih OK. Hasilnya seperti pada Gambar 2.24.

Gambar 2.24

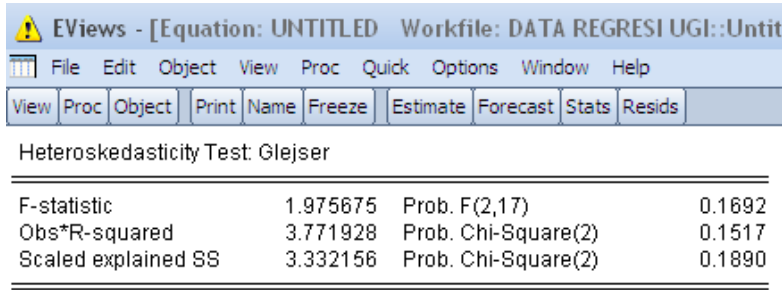

Test Equation:

Dependent Variable: ARESID

Method: Least Squares

Date: 04/22/15 Time: 20:21

Sample: 120

Included observations: 20

\begin{tabular}{crrrr}
\hline \hline Variable & Coefficient & Std. Error & t-Statistic & Prob. \\
\hline \hline C & -0.067194 & 0.371900 & -0.180678 & 0.8588 \\
PENDAPATAN & 0.103465 & 0.063382 & 1.632395 & 0.1210 \\
JUMLAH_ANAK & 0.001819 & 0.093054 & 0.019546 & 0.9846 \\
\hline \hline
\end{tabular}

Gambar 2.25 merupakan hasil uji Glejser berdasarkan SPSS. 


\section{Gambar 2.25}

\begin{tabular}{|c|c|c|c|c|c|c|c|c|}
\hline \multicolumn{9}{|c|}{ Coefficients $^{\Xi}$} \\
\hline \multirow[b]{2}{*}{ Madel } & & \multicolumn{2}{|c|}{ Unstandardized Coefficients } & \multirow{2}{*}{$\begin{array}{c}\begin{array}{c}\text { Standardized } \\
\text { Coefficients }\end{array} \\
\text { Beta } \\
\end{array}$} & \multirow[b]{2}{*}{$t$} & \multirow[b]{2}{*}{ Sig. } & \multicolumn{2}{|c|}{ Collinearity Statistics } \\
\hline & & $B$ & Std. Error & & & & Tolerance & VIF \\
\hline 1 & (Constant) & -.067 & .372 & & -.181 & .859 & & \\
\hline & Pendapatan & .103 & .063 & .431 & 1.632 & .121 & .684 & 1.463 \\
\hline & Jumlah Anak & .002 & .093 & .005 & .020 & .985 & .684 & 1.463 \\
\hline
\end{tabular}

a. Dependent Variable: abs_res

Untuk uji asumsi homoskedastisitas dengan uji White, pilih View $=>$ Residual Diagnostics $\Rightarrow$ Heteroskedasticity Tests (Gambar 2.26), sehingga muncul kotak Heteroskedasticity Tests (Gambar 2.27). Pilih White. Kemudian OK. Hasil berdasarkan uji White diperlihatkan pada Gambar 2.28.

\section{Gambar 2.26}

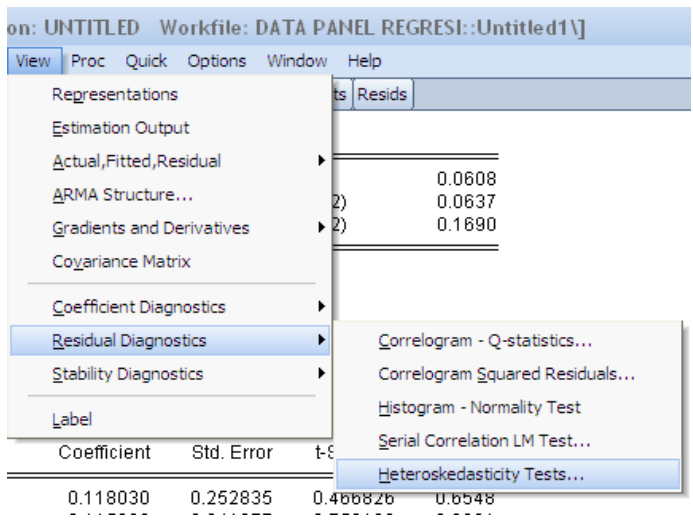

\section{Gambar 2.27}

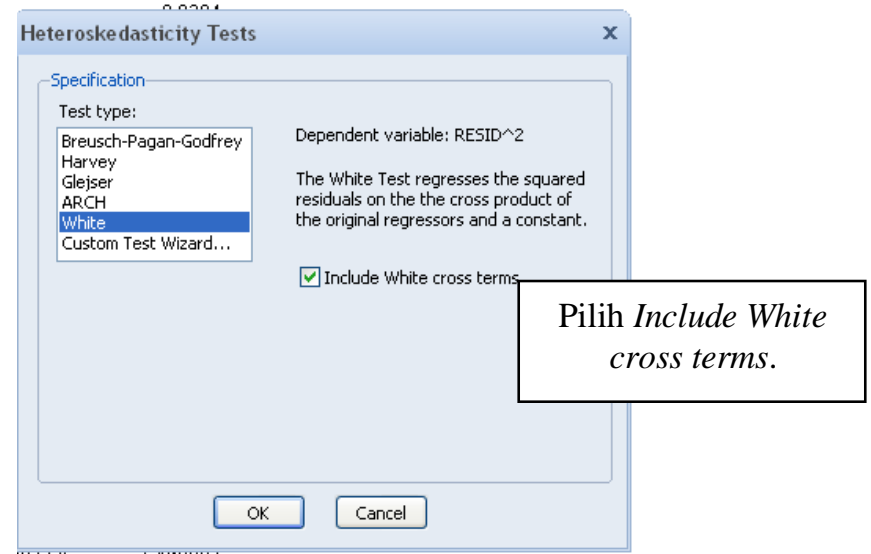


Gambar 2.28

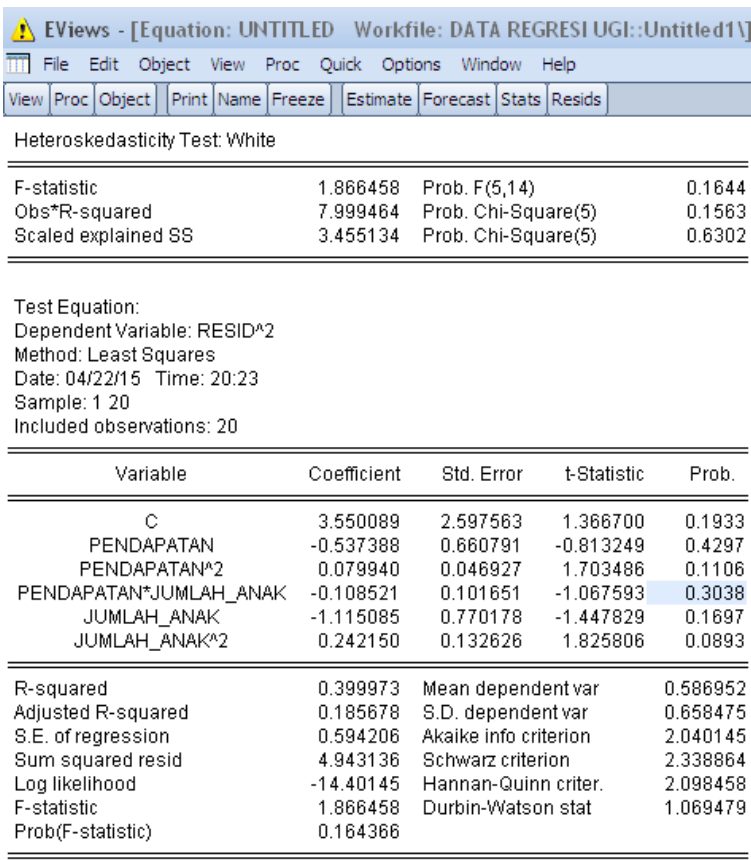

\section{Gambar 2.29 merupakan hasil uji White berdasarkan SPSS.}

Gambar 2.29

Model Summary
\begin{tabular}{|l|c|c|c|c|c|}
\hline Model & $\mathrm{R}$ & $\mathrm{R}$ Square & $\begin{array}{c}\text { Adjusted R } \\
\text { Square }\end{array}$ & $\begin{array}{c}\text { Std. Error of } \\
\text { the Estimate }\end{array}$ & $\begin{array}{c}\text { Durbin- } \\
\text { Watson }\end{array}$ \\
\hline 1 & $.632^{\mathrm{a}}$ & .400 & .186 & .59421 & 1.069 \\
\hline
\end{tabular}
a. Predictors: (Constant), $\times 1 \times 2, \times 1$ pangkat2, Jumlah Anak, Pendapatan,
$\times 2$ pangkat2
b. Dependent Variable: res_kuadrat

\begin{tabular}{|c|c|c|c|c|c|c|}
\hline \multicolumn{7}{|c|}{ ANOVA ${ }^{b}$} \\
\hline & & $\begin{array}{c}\text { Sum of } \\
\text { Squares }\end{array}$ & $\mathrm{df}$ & Mean Square & $\mathrm{F}$ & Sig. \\
\hline \multirow[t]{3}{*}{1} & Regression & 3.295 & 5 & .659 & 1.866 & $.164^{a}$ \\
\hline & Residual & 4.943 & 14 & .353 & & \\
\hline & Total & 8.238 & 19 & & & \\
\hline
\end{tabular}

a. Predictors: (Constant), $\times 1 \times 2, \times 1$ _pangkat2, Jumlah Anak, Pendapatan, $\times 2$ _pangkat2

b. Dependent Variable: res_kuadrat 


\begin{tabular}{|c|c|c|c|c|c|c|c|c|}
\hline \multicolumn{9}{|c|}{ Coefficients $^{a}$} \\
\hline \multirow[b]{2}{*}{ Mad } & & \multicolumn{2}{|c|}{ Unstandardized Coefficients } & \multirow{2}{*}{$\begin{array}{c}\begin{array}{c}\text { Standardized } \\
\text { Coefficients }\end{array} \\
\text { Beta }\end{array}$} & \multirow[b]{2}{*}{$t$} & \multirow[b]{2}{*}{ Siq. } & \multicolumn{2}{|c|}{ Collinearity Statistics } \\
\hline & & $B$ & Std. Error & & & & Tolerance & VIF \\
\hline \multirow[t]{6}{*}{1} & (Constant) & 3.550 & 2.598 & & 1.367 & .193 & & \\
\hline & Pendapatan & -.537 & .661 & -1.644 & -.813 & .430 & .010 & 95.295 \\
\hline & Jumlah Anak & -1.115 & .770 & -2.323 & -1.448 & .170 & .017 & 60.060 \\
\hline & x1_pangkat2 & .080 & .047 & 3.221 & 1.703 & .111 & .012 & 83.435 \\
\hline & ×2_pangkat2 & .242 & .133 & 3.961 & 1.826 & .089 & .009 & 109.826 \\
\hline & $\times 1 \times 2$ & -.109 & .102 & -2.412 & -1.068 & .304 & .008 & 119.093 \\
\hline
\end{tabular}

a. Dependent Variable: res_kuadrat

Untuk uji asumsi homoskedastisitas dengan uji Park, pilih View $=>$ Residual Diagnostics $\Rightarrow$ Heteroskedasticity Tests, sehingga muncul kotak Heteroskedasticity Tests (Gambar 2.30). Pilih Harvey, pada Regressors: ketika $\log$ (pendapatan) $\log ($ jumlah_anak $)$. Kemudian pilih OK. Hasilnya seperti pada Gambar 2.31.

\section{Gambar 2.30}

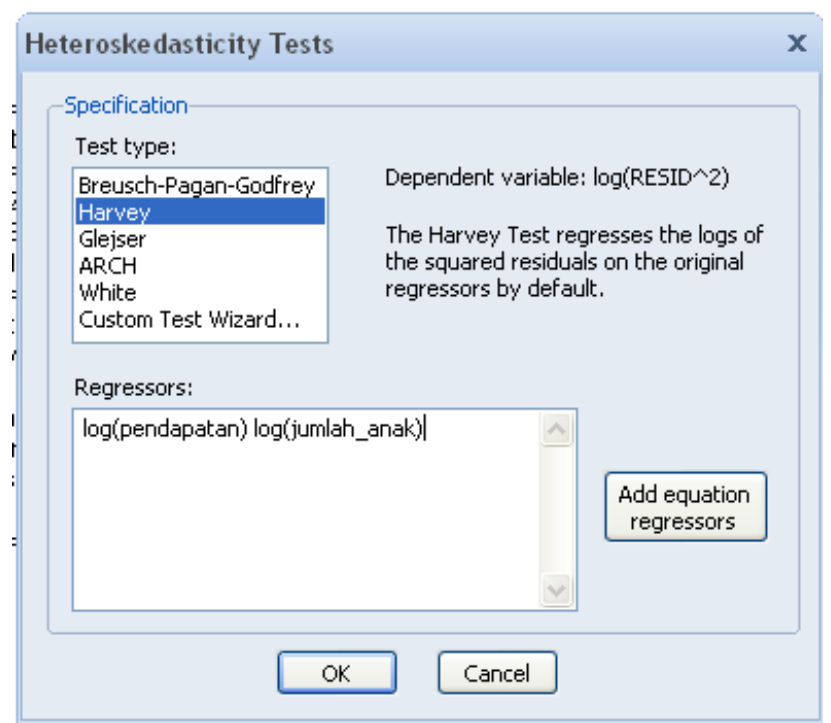




\section{Gambar 2.31}

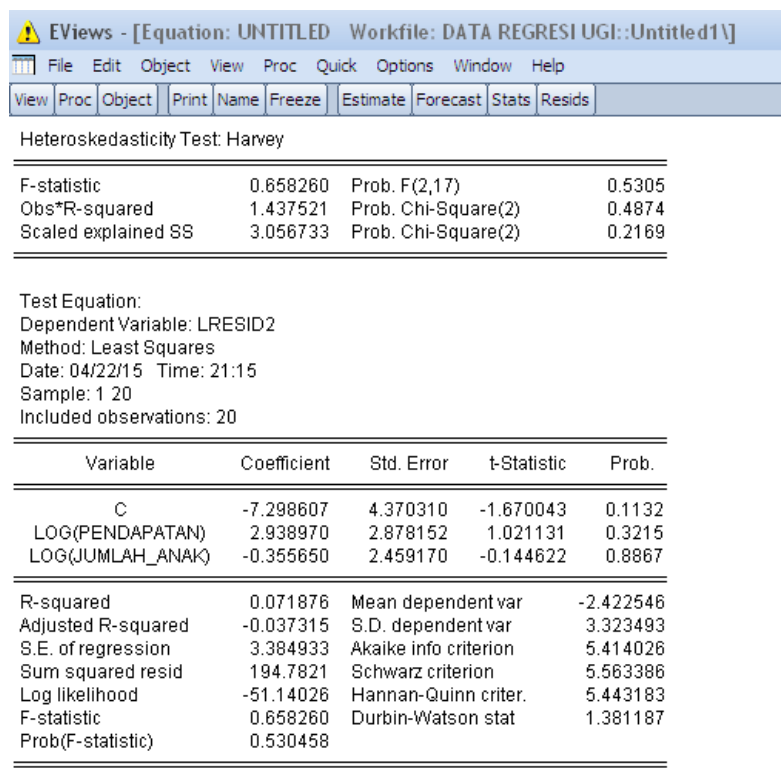

Gambar 2.32 merupakan hasil uji Park berdasarkan SPSS.

Gambar 2.32

\begin{tabular}{|c|c|c|c|c|c|c|}
\hline & & \multicolumn{5}{|c|}{ Coefficients $^{a}$} \\
\hline \multirow[b]{2}{*}{ Madel } & & \multicolumn{2}{|c|}{ Unstandardized Coefficients } & \multirow{2}{*}{$\begin{array}{c}\begin{array}{c}\text { Standardized } \\
\text { Coefficients }\end{array} \\
\text { Beta } \\
\end{array}$} & \multirow[b]{2}{*}{$t$} & \multirow[b]{2}{*}{ Siq. } \\
\hline & & B & Std. Error & & & \\
\hline \multirow[t]{3}{*}{1} & (Constant) & -7.299 & 4.370 & & -1.670 & .113 \\
\hline & $\ln \times 1$ & 2.939 & 2.878 & .289 & 1.021 & .322 \\
\hline & $\ln \times 2$ & -.356 & 2.459 & -.041 & -.145 & .887 \\
\hline
\end{tabular}

a. Dependent Variable: In_kuadrat_RES1

\section{Uji Asumsi Normalitas dengan Q-Q P Plot}

Gambar 2.33 menyajikan nilai residual. Untuk uji asumsi normalitas dengan $Q$ $Q$ Plot, pilih View => Graph...(Gambar 2.34), sehingga muncul kotak Graph Options (Gambar 2.35). Pada Gambar 2.35, pilih Quantile-Quantile dan pada Q-Q graph: pilih Theoretical. Pada Gambar 2.36, atur menjadi Normal, pada Distributions:. 


\section{Gambar 2.33}

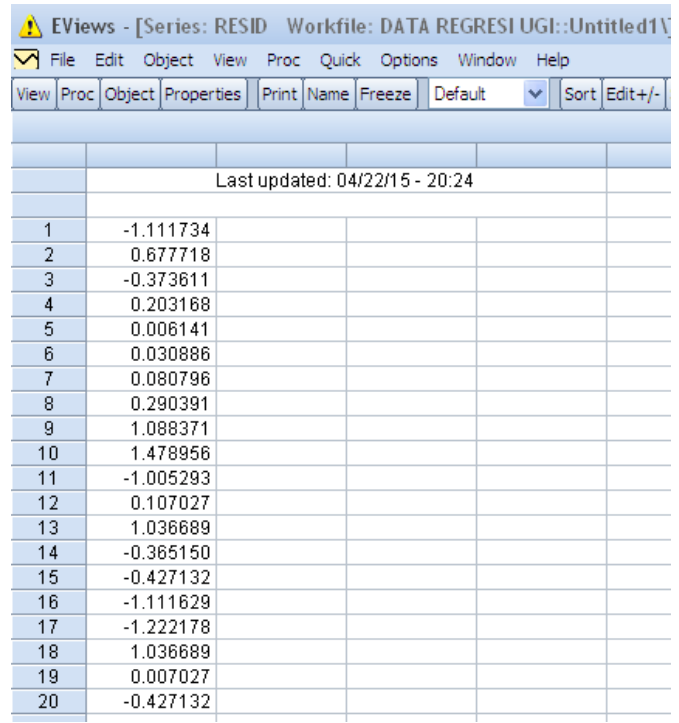

\section{Gambar 2.34}

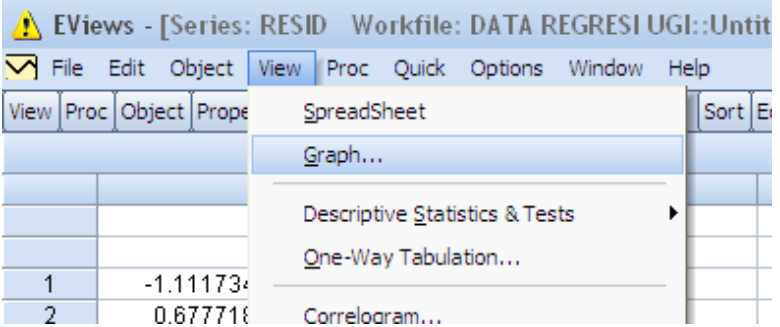

Gambar 2.35

\begin{tabular}{|c|c|c|c|c|c|}
\hline \multicolumn{6}{|l|}{ Graph Options } \\
\hline \multicolumn{6}{|l|}{ Option Pages } \\
\hline \multicolumn{6}{|l|}{$\square$ Graph Type } \\
\hline \multicolumn{6}{|l|}{ Basic type } \\
\hline \multirow{5}{*}{$\begin{array}{l}+ \text { Axes \& Scaling } \\
+ \text { Legend } \\
+ \text { Graph Elements } \\
+ \text { Quick Fonts } \\
\Phi \text { Templates \& Objects }\end{array}$} & Dastil grapin & & & & \\
\hline & Specific: & Q-Q graph: & Theoretical & $\checkmark$ & Options \\
\hline & $\begin{array}{l}\text { Line \& Symbol } \\
\text { Bar }\end{array}$ & Axis borders: & None & & 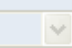 \\
\hline & Spike & & & & \\
\hline & $\begin{array}{l}\text { Area } \\
\text { Dot Plot }\end{array}$ & Multiple series: & Single graph & & $\checkmark$ \\
\hline & $\begin{array}{l}\text { Distribution } \\
\text { Quantile - Quantile } \\
\text { Boxplot }\end{array}$ & & & & \\
\hline
\end{tabular}


Gambar 2.36

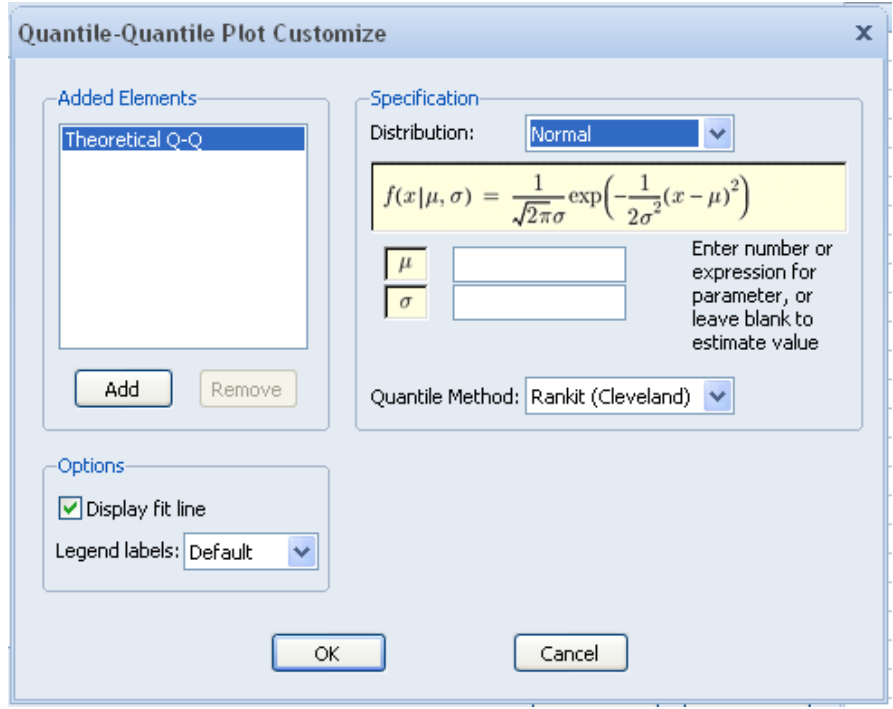

Kemudian pilih OK. Hasilnya seperti pada Gambar 2.37.

Gambar 2.37

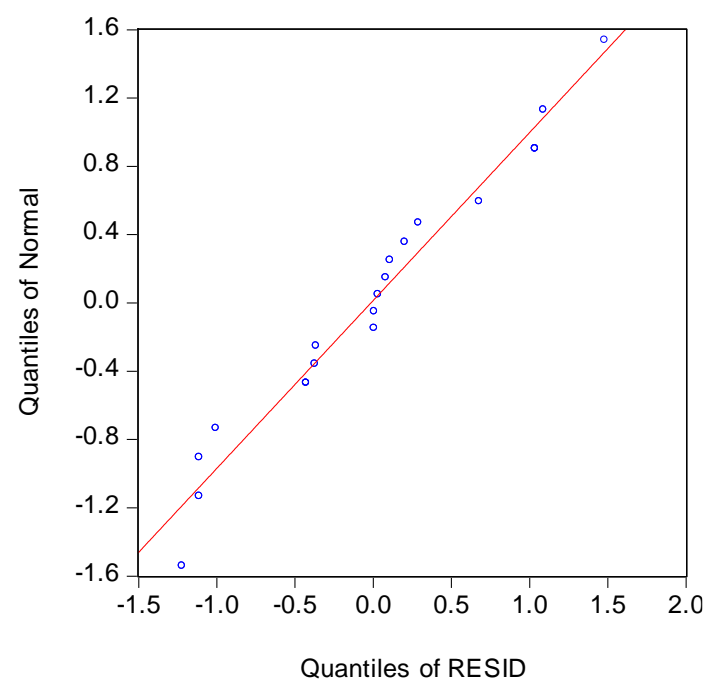




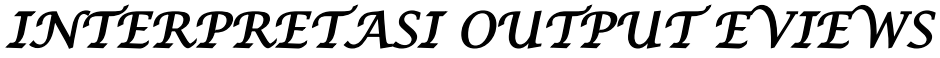

\section{Asumsi Normalitas Error}

Pengujian asumsi normalitas error akan diuji dengan pendekatan analisis grafik, yakni $Q-Q$ plot (Gambar 2.1). Gambar 2.1 merupakan output dari EViews. Pada $Q-Q$ plot (Gambar 2.1), titik-titik menyebar cukup dekat pada garis diagonal, maka disimpulkan bahwa asumsi normalitas dipenuhi.

\section{Gambar 2.1}

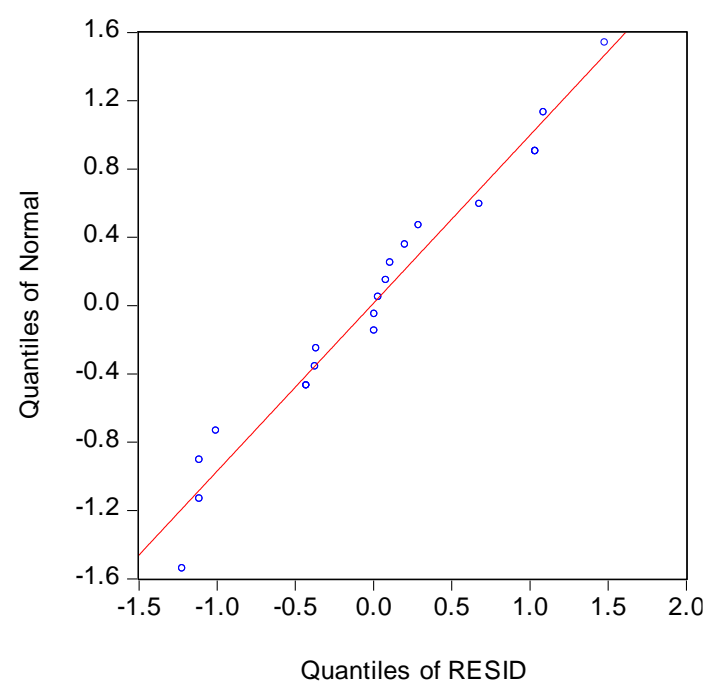

Pada pengujian asumsi normalitas error dengan pendekatan analisis grafik $Q-Q$ plot, disimpulkan bahwa asumsi normalitas error dipenuhi. Berikut akan digunakan pendekatan uji Jarque-Bera untuk menguji asumsi normalitas error. Gambar 2.3 merupakan output EViews untuk uji normalitas dengan uji jarqueBera. Diketahui nilai statistik dari uji Jarque-Bera adalah 0,603823. Gambar 2.2 merupakan perhitungan nilai kritis chi-kuadrat dengan bantuan Microsoft Excel. Berikut aturan pengambilan keputusan terhadap hipotesis.

Jika nilai statistik $J B \leq \chi_{\text {kritis }}^{2}, H_{0}$ diterima dan $H_{1}$ ditolak. Jika nilai statistik $J B>\chi_{\text {kritis }}^{2}, H_{0}$ ditolak dan $H_{1}$ diterima.

Karena nilai statistik dari uji Jarque-Bera, yakni 0,603823, lebih kecil dibandingkan nilai kritis chi-kuadrat, yakni 5,991, maka disimpulkan bahwa 
asumsi normalitas error dipenuhi. Dengan pendekatan probabilitas, diketahui nilai probabilitas, yakni 0,739403 lebih besar dibandingkan tingkat signifikansi, yakni 0,05. Maka disimpulkan bahwa asumsi normalitas error dipenuhi.

\section{Gambar 2.2}

\begin{tabular}{|c|c|c|c|}
\hline \multicolumn{2}{|c|}{ Clipboard } & \multicolumn{2}{|c|}{ Font } \\
\hline \hline & $\mathrm{C} 2$ & $f_{x x}$ & $=\mathrm{CHIINV}(\mathrm{B} 2, \mathrm{~A} 2)$ \\
\hline \hline & $\mathrm{A}$ & $\mathrm{B}$ & $\mathrm{C}$ \\
\hline 1 & $\mathrm{df}$ & tingkat signifikansi & nilai kritis chi-kuadrat \\
\hline 2 & 2 & 0.05 & 5.991464547 \\
\hline 2 & & & \\
\hline
\end{tabular}

\section{Gambar 2.3}

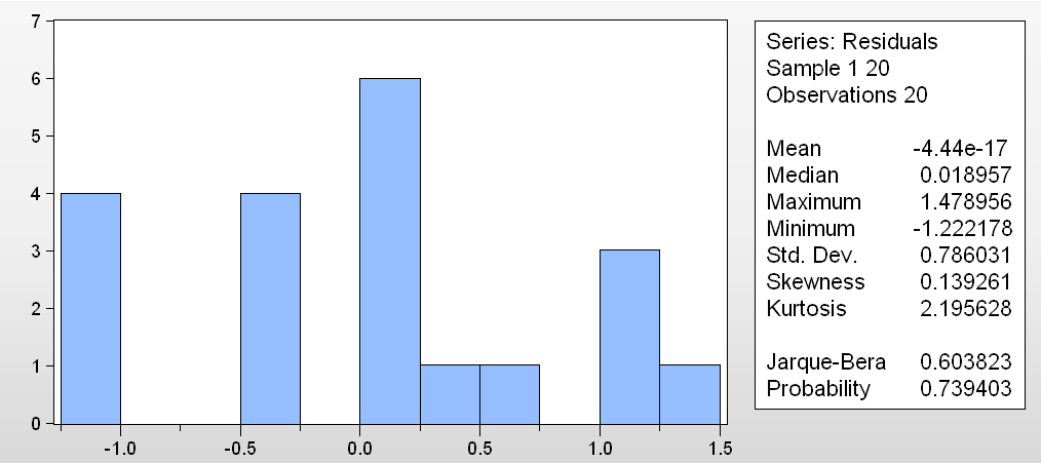

\section{Asumsí Tídak Terjadi Multíkolinearitas}

Untuk mendeteksi apakah terindikasi terjadi gejala multikolinearitas, dapat digunakan pendekatan matriks korelasi dari variabel bebas. Jika terdapat nilai korelasi di atas 0,8 antar variabel bebas, maka diindikasi terjadi multikolinearitas. Gujarati (2003:359) menyatakan sebagai berikut.

"Another suggested rule of thumb is that if the pair-wise or zero-order correlation coefficient between two regressors is high, say, in excess of 0,8 , then multicolinearity is a serious problem".

Output EViews untuk uji asumsi tidak terjadi multikolinearitas disajikan pada Gambar 2.4. 


\section{Gambar 2.4}

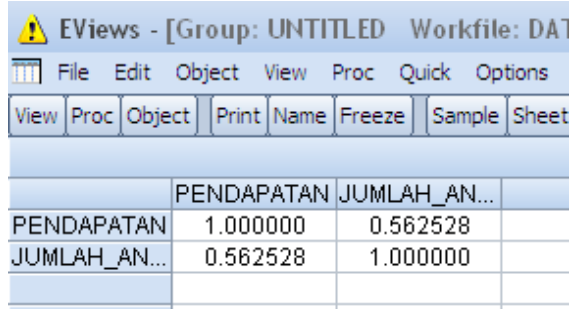

Berdasarkan Gambar 2.4, dapat dilihat bahwa nilai korelasi antara Pendapatan dan Jumlah Anak adalah 0,56, yang mana tidak lebih dari 0,8.

\section{Gambar 2.5}

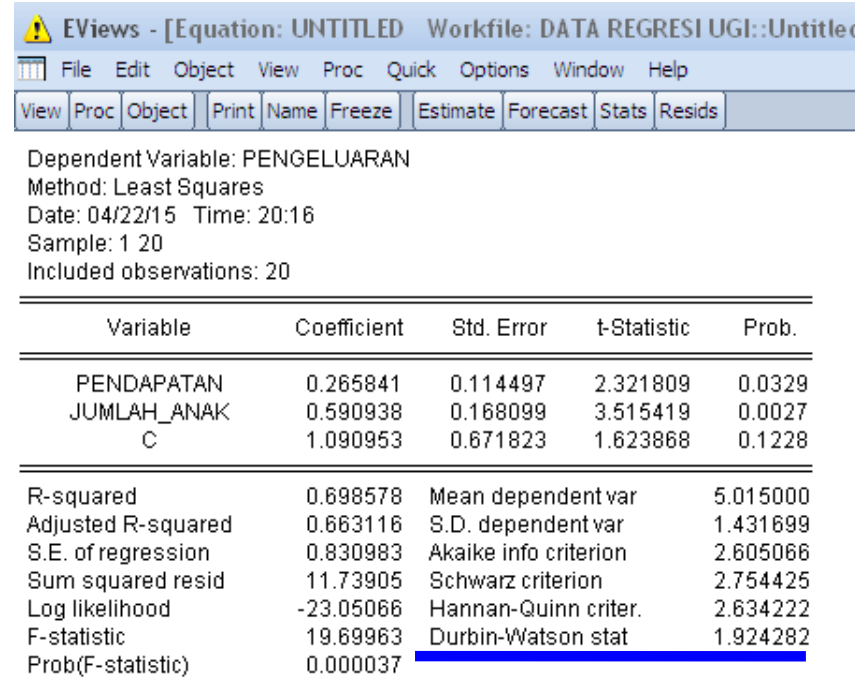

\section{Asumsí Non-Autokorelasí}

Untuk menguji asumsi independensi dari error atau non-autokorelasi, dapat digunakan uji Durbin-Watson. Nilai statistik dari uji Durbin-Watson yang lebih kecil dari 1 atau lebih besar dari 3 diindikasi terjadi autokorelasi. Field (2009:220-221) menyatakan sebagai berikut.

"The size of the Durbin-Watson statistic depends upon the number of predictors in the model and the number of observations. For accuracy, you should look up the exact acceptable values in Durbin and Watson's (1951) 
original paper. As very conservative rule of thumb, values less then 1 or greater than 3 are definitely cause for concern; however, values closer to 2 may stil be problematic depending on your sample and model".

Gambar 2.5 merupakan output EViews yang menyajikan nilai statistik dari uji Durbin-Watson. Diketahui nilai statistik dari uji Durbin-Watson adalah 1,924282, yang mana nilai tersebut berada di antara 1 dan 3. Maka disimpulkan bahwa asumsi non-autokorelasi dipenuhi atau tidak tejadi autokorelasi.

\section{Asumsi Homoskedastísitas}

Asumsi homoskedastisitas menyatakan terjadi kesamaan varians dari error (errors with constant variance) untuk setiap tingkatan atau level dari variabelvariabel bebas. Ketika asumsi homoskedastisitas tidak dipenuhi, maka peristiwa tersebut disebut heteroskedastisitas. Untuk mendeteksi terjadinya gejala heteroskedastisitas dapat dilakukan dengan menggunakan uji Park, uji Glejser, dan uji White. Gambar 2.6 merupakan output EViews untuk uji asumsi homoskedastisitas dengan uji Park. Diketahui nilai probabilitas untuk koefisien regresi LOG(PENDAPATAN) dan LOG(JUMLAH_ANAK) masing-masing adalah 0,3215 dan 0,8867 , yang mana keduanya tidak signifikan secara statistik pada tingkat signifikansi 0,05. Maka disimpulkan bahwa asumsi homoskedastisitas dipenuhi.

Gambar 2.7 merupakan output EViews untuk uji asumsi homoskedastisitas dengan uji Glejser. Diketahui nilai probabilitas untuk koefisien regresi PENDAPATAN dan JUMLAH_ANAK masing-masing adalah 0,1210 dan 0,9846, yang mana keduanya tidak signifikan secara statistik pada tingkat signifikansi 0,05. Maka disimpulkan bahwa asumsi homoskedastisitas dipenuhi.

Gambar 2.8 merupakan output EViews untuk uji asumsi homoskedastisitas dengan uji White. Berikut hasil kali antara nilai koefisien determinasi $(R$ Squared) dan ukuran sampel (sample size).

$$
0,399973 \times 20=7,99946 \text {. }
$$

Selanjutnya akan dihitung nilai kritis chi-kuadrat dengan nilai derajat bebas 5 dengan bantuan software Microsoft Excel (Gambar 2.9). Diketahui nilai kritis chi-kuadrat adalah 11,07. Perhatikan bahwa karena hasil kali antara nilai koefisien determinasi ( $R$-Squared) dan ukuran sampel (sample size), yakni 7,99946, lebih kecil dibandingkan nilai kritis chi-kuadrat, yakni 11,07, maka disimpulkan bahwa hipotesis nol diterima, yakni tidak terjadi heteroskedastisitas. 


\section{Gambar 2.6}

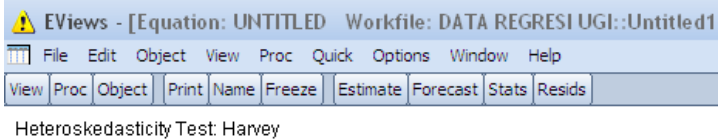

\begin{tabular}{llll}
\hline \hline F-statistic & 0.658260 & Prob. F(2,17) & 0.5305 \\
Obs*R-squared & 1.437521 & Prob. Chi-Square(2) & 0.4874 \\
Scaled explained SS & 3.056733 & Prob. Chi-Square(2) & 0.2169 \\
\hline \hline
\end{tabular}

Test Equation:

Dependent Variable: LRESID2

Method: Least Squares

Date: 04/22/15 Time: 21:15

Sample: 120

Included observations: 20

\begin{tabular}{crrrr}
\hline \hline \multicolumn{1}{c}{ Variable } & Coefficient & Std. Error & t-Statistic & Prob. \\
\hline \hline C & -7.298607 & 4.370310 & -1.670043 & 0.1132 \\
LOG(PENDAPATAN) & 2.938970 & 2.878152 & 1.021131 & 0.3215 \\
LOG(JUMLAH_ANAK) & -0.355650 & 2.459170 & -0.144622 & 0.8867 \\
\hline \hline R-squared & 0.071876 & Mean dependent var & -2.422546 \\
Adiusted R-squared & -0.037315 & S.D. dependent var & 3.323493
\end{tabular}

\section{Gambar 2.7}

!) EViews - [Equation: UNTITLED Workfile: DATA REGRESI UGI::Untit
I7] File Edit Object View Proc Quick Options Window Help
View [Proc [Object] [Print $[$ Name [Freeze] [Estimate [Forecast $[$ Stats $[$ Resids $]$

Heteroskedasticity Test: Glejser

\begin{tabular}{llll}
\hline \hline F-statistic & 1.975675 & Prob. F(2,17) & 0.1692 \\
Obs*R-squared & 3.771928 & Prob. Chi-Square(2) & 0.1517 \\
Scaled explained SS & 3.332156 & Prob. Chi-Square(2) & 0.1890 \\
\hline \hline
\end{tabular}

Test Equation:

Dependent Variable: ARESID

Method: Least Squares

Date: 04/22/15 Time: 20:21

Sample: 120

Included observations: 20

\begin{tabular}{crrrr}
\hline \hline Variable & Coefficient & Std. Error & t-Statistic & Prob. \\
\hline \hline C & -0.067194 & 0.371900 & -0.180678 & 0.8588 \\
PENDAPATAN & 0.103465 & 0.063382 & 1.632395 & 0.1210 \\
JUMLAH_ANAK & 0.001819 & 0.093054 & 0.019546 & 0.9846 \\
\hline \hline
\end{tabular}




\section{Gambar 2.8}

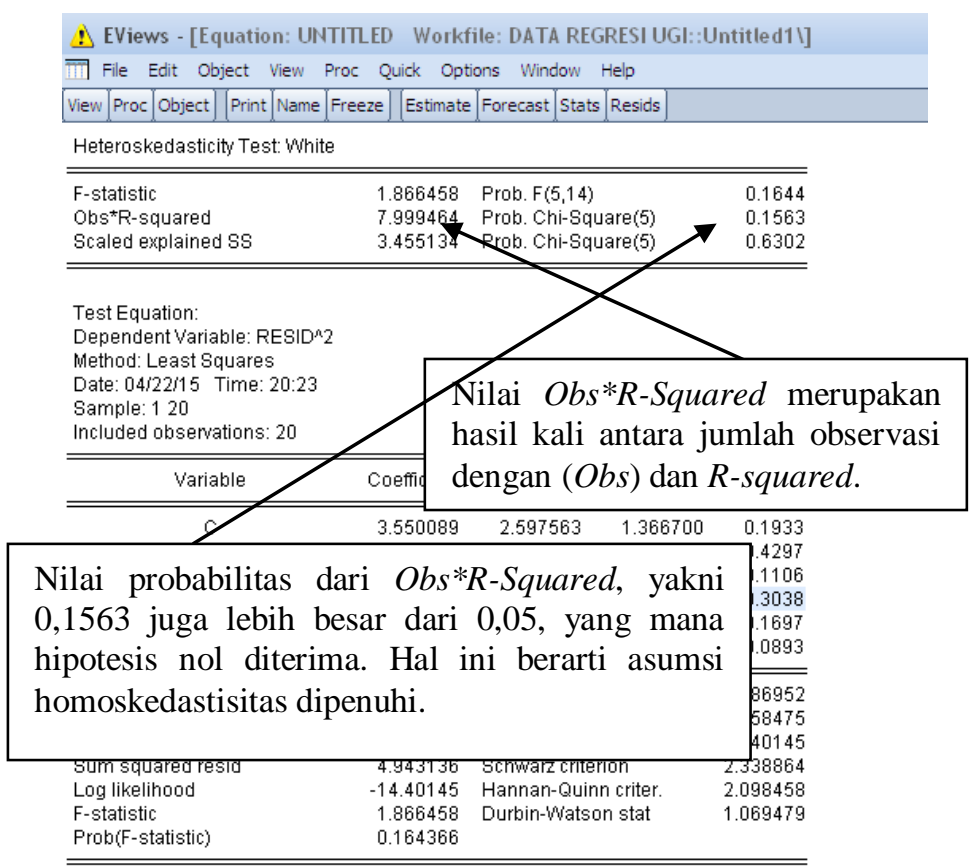

\section{Gambar 2.9}

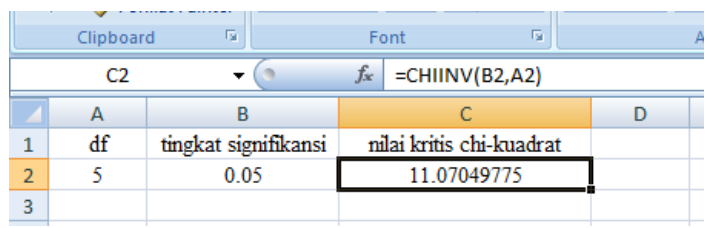

\section{Mengukur Kecocokkan Model Regresi Linear Berganda terhadap Data dengan Koefisien Determinasi $\left(r^{2}\right)$}

Berdasarkan Gambar 2.5, diketahui nilai koefisien determinasi ( $R$-Squared) 0,698578. Nilai tersebut dapat diinterpretasikan sebagai variabel pendapatan dan jumlah anak mampu menjelaskan atau menerangkan variabel pengeluaran sebesar $69,86 \%$, sisanya sebesar $30,14 \%$ dijelaskan oleh variabel-variabel lain. 


\section{Menguji Sígnifikansi Kecocokkan Model Regresi Linear terhadap Data dengan Uji $F$}

Berdasarkan Gambar 2.5, diketahui nilai statistik dari uji $F$ adalah 19,69.

$$
\begin{aligned}
& d f 1=\text { Derajat bebas pembilang }=k-1=3-1=2 . \\
& d f 2=\text { Derajat bebas penyebut }=n-k=20-3=17 .
\end{aligned}
$$

Berikut perhitungan nilai kritis $F$ (F tabel) berdasarkan Microsoft Excel (Gambar 2.10).

\begin{tabular}{|c|c|c|c|c|c|c|}
\hline & \multirow{2}{*}{\multicolumn{2}{|c|}{$\begin{array}{c}\text { Clipboard } \\
\text { D2 }\end{array}$}} & \multicolumn{2}{|c|}{ Font } & (a) & \\
\hline & & & $f_{x}$ & $=\mathrm{FIN}$ & $(\mathrm{C} 2, \mathrm{~A} 2, \mathrm{~B} 2)$ & \\
\hline 4 & A & B & C & & D & $E$ \\
\hline 1 & df1 & $\mathrm{df} 2$ & tingkat signifi & kansi & Nilai Kritis F & \\
\hline 2 & 2 & 17 & 0.05 & & 3.591530569 & \\
\hline
\end{tabular}

\section{Gambar 2.10}

Perhatikan bahwa karena nilai statistik dari uji $F$, yakni 19,69 lebih besar dibandingkan nilai kritis $F$, yakni 3,591, maka disimpulkan bahwa pengaruh simultan atau bersama-sama dari variabel bebas pendapatan dan jumlah anak terhadap pengeluaran signifikan secara statistik pada tingkat signifikansi $5 \%$.

Selain pendekatan nilai kritis, dapat juga digunakan pendekatan nilai probabilitas. Berdasarkan Gambar 2.5, diketahui nilai probabilitas dari nilai statistik dari uji $F$ (Prob(F-statistic)) adalah 0,000037. Karena nilai probabilitas tersebut lebih kecil dibandingkan tingkat signifikansi, yakni 0,05, maka disimpulkan bahwa pengaruh simultan atau bersama-sama dari variabel bebas pendapatan dan jumlah anak terhadap pengeluaran signifikan secara statistik pada tingkat signifikansi $5 \%$.

\section{Uji Signifikansi Koefísien Regresi Secara Individu dengan Ujút}

Berikut akan ditentukan apakah faktor pendapatan mempengaruhi pengeluaran secara signifikan (signifikan secara statistik), dengan mengontrol pengaruh jumlah anak. Output EViews untuk uji signifikansi koefisien regresi populasi secara individu dengan uji $t$ disajikan pada Gambar 2.5. Berdasarkan Gambar 2.5, nilai statistik dari uji $t$ untuk variabel pendapatan adalah 2,3218. Nilai kritis $t$ dengan derajat bebas $n-k=20-3=17$ dan tingkat signifikansi $5 \%$ adalah $\pm 2,110$. 


\section{Gambar 2.11}

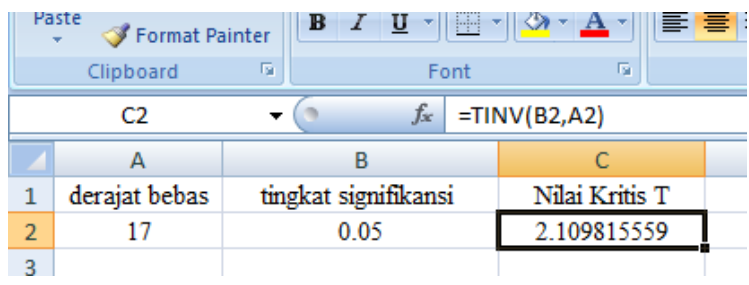

Berikut aturan pengambilan keputusan terhadap hipotesis berdasarkan uji $t$.

$$
\begin{aligned}
& \text { Jika }\left|t_{\text {hitung }}\right| \leq\left|t_{\text {kritis }}\right| \text {, maka } H_{0} \text { diterima dan } H_{1} \text { ditolak. } \\
& \text { Jika }\left|t_{\text {hitung }}\right|>\left|t_{\text {kritis }}\right|, \text { maka } H_{0} \text { ditolak dan } H_{1} \text { diterima. }
\end{aligned}
$$

Perhatikan bahwa karena $\left|t_{\text {hitung }}\right|>\left|t_{\text {kritis }}\right|$, yakni 2,3128 $>2,110$, maka disimpulkan bahwa faktor pendapatan mempengaruhi pengeluaran secara signifikan (signifikan secara statistik), dengan mengontrol pengaruh jumlah anak.

Pengambilan keputusan terhadap hipotesis juga dapat dilakukan dengan menggunakan pendekatan nilai probabilitas dari uji $t$. Nilai probabilitas dari uji $t$ berdasarkan variabel pendapatan adalah 0,0329 . Karena nilai probabilitas tersebut lebih kecil dibandingkan tingkat signifikansi $\alpha=5 \%$, maka disimpulkan bahwa faktor pendapatan mempengaruhi pengeluaran secara signifikan (signifikan secara statistik), dengan mengontrol pengaruh jumlah anak.

Diketahui nilai koefisien regresi untuk variabel pendapatan adalah 0,266. Nilai tersebut dapat diinterpretasikan ketika pendapatan bertambah Rp.1 juta, maka secara rata-rata (on average) pengeluaran meningkat sebesar Rp.266.000, ketika pengaruh dari jumlah anak dipertahankan konstan.

Selanjutnya akan ditentukan apakah faktor jumlah anak mempengaruhi pengeluaran secara signifikan (signifikan secara statistik), dengan mengontrol pengaruh pendapatan. Berdasarkan Gambar 2.5, nilai statistik dari uji $t$ untuk variabel jumlah anak adalah 3,515. Nilai kritis $t$ dengan derajat bebas $n-k=$ $20-3=17$ dan tingkat signifikansi $5 \%$ adalah $\pm 2,110$.

Perhatikan bahwa karena $\left|t_{\text {hitung }}\right|>\left|t_{\text {kritis }}\right|$, yakni 3,515 $>2,110$, maka disimpulkan bahwa faktor jumlah anak mempengaruhi pendapatan secara signifikan (signifikan secara statistik), dengan mengontrol pengaruh pendapatan. Nilai probabilitas (Sig) dari uji $t$ berdasarkan variabel jumlah anak adalah 0,0027. Karena nilai probabilitas tersebut lebih kecil dibandingkan tingkat signifikansi $\alpha=5 \%$, maka disimpulkan bahwa faktor jumlah anak 
mempengaruhi pengeluaran secara signifikan (signifikan secara statistik), dengan mengontrol pengaruh pendapatan.

Diketahui nilai koefisien regresi untuk variabel jumlah anak adalah 0,59. Nilai tersebut dapat diinterpretasikan ketika jumlah anak bertambah satu, maka secara rata-rata (on average) pengeluaran meningkat sebesar Rp.590.000, ketika pengaruh dari pendapatan dipertahankan konstan. Perhatikan bahwa variabel jumlah anak memberikan kontribusi yang terbesar terhadap kenaikkan pengeluaran dalam suatu keluarga.

\section{Referensi}

1. Agresti, A. dan B. Finlay. 2009. Statistical Methods for the Social Sciences, $4^{\text {th }}$ Edition. United States of America: Prentice Hall.

2. Field, A. 2009. Discovering Statistics Using SPSS, $3^{\text {rd }}$ Edition. London: Sage.

3. Gio, P.U. 2013. Aplikasi Statistika dalam SPSS. Medan: USUpress.

4. Gujarati, D.N. 2003. Basic Econometrics, $4^{\text {th }}$ Edition. New York: McGraw-Hill.

5. Hair, J.F Jr., R.E. Anderson, B.J. Babin, dan W.C. Black. 2010. Multivariate Data Analysis, $7^{\text {th }}$ Edition. Pearson Prentice Hall.

6. Johnson, R.A. dan D.W. Wichern. 2007. Applied Multivariate Statistical Analysis, $6^{\text {th }}$ Edition. United States of America: Prentice Hall.

7. Malhotra, N.K. dan D.F. Birks. 2006. Marketing Research, An Applied Approach, $2^{\text {nd }}$ European Edition. London: Prentice Hall.

8. Montgomery, D.C. dan G.C. Runger. 2011. Applied Statistics and Probability for Engineers, $5^{\text {th }}$ Edition. United States of America: John Wiley \& Sons, Inc.

9. Stevens, J.P. 2009. Applied Multivariate Statistics For The Social Science, $5^{\text {th }}$ Edition. New York: Routledge.

10. Supranto, J. 2004. Ekonometri, Buku Kedua. Jakarta: Ghalia Indonesia.

11. Supranto, J. 2005. Ekonometri, Buku Kesatu. Jakarta: Ghalia Indonesia. 


\section{REGRESI DATA PANEL}

\section{Sekilas Mengenai Data Cross-Section, Data Tíme Series, dan Data Panel}

Gujarati (2003:27) menyatakan data cross-section merupakan suatu data yang terdiri dari satu atau lebih variabel yang dikumpulkan pada waktu yang sama (at the same point in time). Tabel 3.1 merupakan contoh dari data cross-section.

Tabel 3.1 Pendapatan dan pengeluaran dari 4 perusahaan pada tahun 2000 (dalam milyar) (data fiktif)

\begin{tabular}{|c|c|c|}
\hline Nama Perusahaan & Pendapatan $(X)$ & Pengeluaran $(Y)$ \\
\hline Perusahaan A & 35 & 22 \\
\hline Perusahaan B & 21 & 15 \\
\hline Perusahaan C & 99 & 56 \\
\hline Perusahaan D & 27 & 12 \\
\hline
\end{tabular}

Data cross-section pada Tabel 3.1 terdiri atas dua variabel, yakni pendapatan $(X)$ dan pengeluaran $(Y)$. Data pendapatan dan pengeluaran dari empat perusahaan tersebut dikumpulkan pada waktu yang sama, yakni pada tahun 2000. Selain data cross-section, terdapat jenis data lain, yakni data time series. Pada data time series, serangkaian nilai-nilai pengamatan dari suatu variabel dikumpulkan berdasarkan waktu yang berbeda-beda (Gujarati, 2003:25). Tabel 3.2 merupakan contoh dari data time series.

Tabel 3.2 Pendapatan dan pengeluaran pada perusahaan A dalam periode 2000-2005 (dalam milyar) (data fiktif)

\begin{tabular}{|c|c|c|}
\hline Tahun & Pendapatan $(X)$ & Pengeluaran $(Y)$ \\
\hline 2000 & 35 & 22 \\
\hline 2001 & 21 & 15 \\
\hline 2002 & 99 & 56 \\
\hline 2003 & 27 & 12 \\
\hline 2004 & 46 & 27 \\
\hline 2005 & 66 & 36 \\
\hline
\end{tabular}


Data time series pada Tabel 3.2 menyajikan tingkat pendapatan $(X)$ dan pengeluaran $(Y)$ dari perusahaan A selama enam tahun, yakni dari tahun 2000 sampai tahun 2005 .

Data yang memuat unsur time series dan cross-section disebut dengan data panel. Data panel disebut juga dengan pooled data (pooling of time series and cross sectional observations), combination of time series and cross section data, micropanel data (Gujarati, 636:2003). Tabel 3.3 merupakan contoh dari data panel.

Tabel 3.3 Pendapatan dan pengeluaran pada perusahaan A, B, C, dan D dalam periode 2000-2002 (dalam milyar)

\begin{tabular}{|c|c|c|c|}
\hline Nama Perusahaan & Tahun & Pendapatan $(X)$ & Pengeluaran $(Y)$ \\
\hline Perusahaan A & 2000 & 35 & 26 \\
\hline Perusahaan A & 2001 & 36 & 27 \\
\hline Perusahaan A & 2002 & 32 & 24 \\
\hline Perusahaan B & 2000 & 41 & 33 \\
\hline Perusahaan B & 2001 & 42 & 32 \\
\hline Perusahaan B & 2002 & 44 & 36 \\
\hline Perusahaan C & 2000 & 43 & 39 \\
\hline Perusahaan C & 2001 & 41 & 31 \\
\hline Perusahaan C & 2002 & 46 & 36 \\
\hline Perusahaan D & 2000 & 23 & 19 \\
\hline Perusahaan D & 2001 & 28 & 18 \\
\hline Perusahaan D & 2002 & 25 & 19 \\
\hline
\end{tabular}

Berdasarkan data pada Tabel 3.3, diketahui terdapat 4 unit cross-sectional dan 3 waktu pengamatan, maka jumlah pengamatan (observation) sebanyak

$$
3 \times 6=12 \text { pengamatan } \text {. }
$$

Untuk setiap pengamatan dapat dinyatakan dalam persamaan sebagai berikut.

$$
\begin{gathered}
\text { Pengeluaran }_{i, t}=\beta_{1}+\beta_{2} \text { Pendapatan }_{i, t}+u_{i, t}, \\
i=1,2,3,4 \\
t=1,2,3 .
\end{gathered}
$$

Misalkan $i$ menyatakan unit cross-sectional ke- $i$ dan $t$ menyatakan waktu pengamatan ke- $t$. Perhatikan bahwa

$$
\begin{aligned}
\text { Pengeluaran }_{1,1} & =\beta_{1}+\beta_{2} \text { Pendapatan }_{1,1}+u_{1,1}, \\
26 & =\beta_{1}+35 \beta_{2}+u_{1,1},
\end{aligned}
$$




$$
\begin{aligned}
\text { Pengeluaran }_{3,2} & =\beta_{1}+\beta_{2} \text { Pendapatan }_{3,2}+u_{3,2}, \\
31 & =\beta_{1}+41 \beta_{2}+u_{3,2},
\end{aligned}
$$

dan seterusnya. Berdasarkan data pada Tabel 3.3, perhatikan bahwa masingmasing unit cross-sectional memiliki jumlah waku pengamatan yang sama. Pada unit cross-sectional Perusahaan A, memiliki 3 waktu pengamatan, yakni mulai dari tahun 2000, 2001, dan 2002. Begitu juga pada unit cross-sectional Perusahaan B memiliki 3 waktu pengamatan, yakni dari tahun 2000, 2001, dan 2002. Data panel yang demikian disebut juga dengan istilah balanced panel. Namun, jika jumlah waktu pengamatan tidak sama atau berbeda-beda, maka disebut unbalanced panel.

\section{Keuntungan Menggunakan Data Panel}

Beberapa keuntungan menggunakan data panel sebagai berikut (Baltagi dalam Gujarati, 2003:637-638).

1. Unit-unit cross-sectional pada data panel dapat berupa individuindividu, perusahaan-perusahaan, negara-negara, dan sebagainya. Karena unit-unit cross-sectional pada data panel diamati dalam rangkaian kurun waktu tertentu (over time), maka akan terjadi keragaman atau heterogenitas (heterogeneity) dalam tiap-tiap unit cross-sectional. Teknik-teknik estimasi data panel dapat mengakomodasi atau memperhitungkan tingkat heterogenitas unit-unit cross-sectional secara eksplisit.

2. Dengan mengkombinasikan pengamatan-pengamatan time series dan cross-section, data panel menyajikan data yang lebih informatif (more informative) dan beragam (variability), pengaruh kolinearitas antar variabel berkurang (less collinearity among variables), meningkatkan nilai derajat bebas, serta lebih efisien.

3. Dengan mempelajari pengamatan unit-unit cross-sectional yang berulang-ulang (repeated cross-section of observations), data panel lebih baik (panel data are better suited) untuk mempelajari dinamika perubahan (dynamics of change).

4. Data panel dapat lebih baik dalam hal mendeteksi dan mengukur pengaruh-pengaruh yang tidak dapat diobservasi (cannot be observed) dalam data cross-section murni atau data time series murni.

5. Data panel memungkinkan untuk mempelajari model perilaku yang lebih rumit. Sebagai contoh, fenomena mengenai economies of scale dan perubahan teknologi dapat ditangani lebih baik (can be better 
handled) dengan data panel, daripada menggunakan data cross-section murni atau data time series murni.

\section{Estimasi Model Regresi Data Panel (Pendekatan Fixed Effects)}

Judge dan Hsiao dalam (Gujarati, 2003:640) menyatakan estimasi dari model regresi data panel pada persamaan [3.1] bergantung pada asumsi-asumsi mengenai intersep (intercept), koefisien-koefisien kemiringan (slope coefficients), dan error $u_{i t}$. Berikut beberapa kemungkinan dari model regresi data panel:

1. Model regresi data panel yang mengasumsikan (assume) intersep dan koefisien-koefisien kemiringan bersifat konstan sepanjang unit-unit cross-sectional dan waktu pengamatan (time series), serta error menangkap perbedaan-perbedaan (error term captures differences) sepanjang unit-unit cross-sectional dan waktu pengamatan (time series).

2. Model regresi data panel yang mengasumsikan koefisien-koefisien kemiringan bersifat konstan, namun intersep bervariasi (varies) terhadap unit-unit cross-sectional atau individu-individu (over individuals).

3. Model regresi data panel yang mengasumsikan koefisien-koefisien kemiringan bersifat konstan, namun intersep bervariasi terhadap individu-individu dan waktu pengamatan (over individuals and time).

4. Model regresi data panel yang mengasumsikan seluruh koefisien (intersep dan juga koefisien-koefisien kemiringan) bervariasi terhadap individu-individu (over individuals).

5. Model regresi data panel yang mengasumsikan intersep dan juga koefisien-koefisien kemiringan bervariasi terhadap individu-individu (individuals) dan waktu pengamatan (time).

\section{Model Regresi Data Panel dengan Intersep dan Koefísien- Koefísien Kemiringan Konstan}

Pada model regresi data panel dengan intersep dan koefisien-koefisien kemiringan diperlakukan konstan sepanjang unit cross-sectional dan time series, tidak dapat dilihat apakah terdapat perbedaan yang signifkan (secara statistik) antar unit cross-sectional atau antar periode waktu pengamatan. Metode estimasi parameter yang digunakan adalah metode ordinary least squares (OLS). Persamaan untuk model regresi data panel dengan intersep dan 
koefisien-koefisien kemiringan diperlakukan konstan tersaji pada persamaan [3.1]. Model persamaan [3.1] disebut juga dengan istilah common effects model (CEM).

\section{Model Regresi Data Panel dengan Intersep Bervariasi sepanjang Unit Cross-Sectional, namun Koefisien-Koefisien Kemiringan Konstan (Fixed Effects Model)}

Gujarati (2003:642) menyatakan salah satu cara untuk melihat ada tidaknya perbedaan antar unit cross-sectional adalah dengan cara membiarkan nilai intersep bervariasi untuk setiap unit cross-sectional, namun dengan tetap memperlakukan konstan terhadap koefisien-koefisien kemiringan. Berdasarkan model persamaan [3.1], maka model regresi data panel dengan intersep bervariasi sepanjang unit cross-sectional, namun koefisien-koefisien kemiringan konstan dapat dinyatakan dalam persamaan sebagai berikut.

$$
\text { Pengeluaran }_{i, t}=\beta_{1 i}+\beta_{2} \text { Pendapatan }_{i, t}+u_{i, t} \text {. }
$$

Berdasarkan persamaan [3.2], perhatikan bahwa pada intersep terdapat subskrip $i$, yang berarti bahwa nilai intersep akan bervariasi untuk setiap unit crosssectional ke- $i$. Dalam hal ini, $\beta_{11}$ merupakan intersep untuk unit crosssectional ke-1, $\beta_{12}$ merupakan intersep untuk unit cross-sectional ke-2, dan seterusnya. Gujarati (2003:642) menyatakan model persamaan [3.2] disebut juga dengan istilah fixed effects (regression) model (FEM). Istilah "fixed effects" dikarenakan intersep dapat berbeda sepanjang unit cross-sectional, namun intersep tersebut tidak berubah atau tidak berbeda disepanjang waktu pengamatan (over time) (time invariant). Seandainya pada intersep dinyatakan dengan $\beta_{1 i t}$, maka intersep untuk setiap unit cross-sectional akan bervariasi sepanjang waktu pengamatan (time variant).

Gujarati (2003:642) mengemukakan cara untuk menyatakan model regresi data panel fixed effects model, yakni dengan menggunakan teknik variabel dummy, yang mana persamaannya dinyatakan sebagai berikut.

$$
\begin{aligned}
\text { Pengeluaran }_{i, t} & =\alpha_{1}+\alpha_{2} D_{2 i}+\alpha_{3} D_{3 i}+\alpha_{4} D_{4 i}+\beta_{2} \text { Pendapatan }_{i, t} \\
& +u_{i, t}
\end{aligned}
$$

Perhatikan bahwa $D_{2 i}=1$ untuk unit cross-sectional ke-2, sementara yang lain bernilai $0 . D_{3 i}=1$ untuk unit cross-sectional ke-3, sementara yang lain bernilai 0. $D_{4 i}=1$ untuk unit cross-sectional ke-4, sementara yang lain bernilai 0. Perlu diperhatikan bahwa untuk unit cross-sectional ke-1 tidak memiliki variabel dummy. Perhatikan juga bahwa $\alpha_{1}$ merupakan intersep untuk unit crosssectional ke-1. Untuk $\alpha_{2}, \alpha_{3}$, dan $\alpha_{4}$ menjelaskan seberapa besar intersep dari unit cross-sectional ke-2,3, dan 4 berbeda dari intersep unit cross-sectional ke1. Dengan kata lain, unit cross-sectional ke-1 menjadi basis perbandingan. 
Namun tentunya, dapat juga diatur untuk menetapkan unit cross-sectional tertentu untuk menjadi basis perbandingan. Gujarati (2003:642-643) menyatakan model persamaan [3.33] disebut juga dengan istilah least-squares dummy variable (LSDV) model atau disebut juga covariance model.

\section{Estimasi Model Regresi Data Panel (Pendekatan Random Effects (REM))}

Model regresi data panel random effect disebut juga dengan istilah error component model (ECM). Salah satu perbedaan antara fix effects model (FEM) dan error component model (ECM) adalah pada FEM, intersep $\beta_{1 i}$ diperlakukan tetap (treating $\beta_{1 i}$ as fixed), sementara pada ECM, intersep bersifat random variable dengan nilai rata-rata (mean) $\beta_{1}$. Gujarati (2003:647) menyatakan sebagai berikut.

"Instead of treating $\beta_{1 i}$ as fixed, we assumed that it is a random variable with a mean value of $\beta_{1}$ (no subscript $i$ here)".

Pada ECM, intersep dari unit cross-sectional dinyatakan sebagai berikut.

$$
\beta_{1 i}=\beta_{1}+\varepsilon_{i}, \quad i=1,2,3, \ldots, N \quad[3.4]
$$

Perhatikan bahwa $\varepsilon_{i}$ menyatakan random error dengan nilai rata-rata 0 dan varians $\sigma_{\varepsilon}^{2}$. Pada ECM mengasumsikan jumlah unit cross-sectional dalam sampel ditarik dari populasi yang berukuran besar (jumlah unit cross-sectional dari suatu populasi besar atau banyak), dengan $\beta_{1}$ merupakan nilai rata-rata intersep (populasi), serta nilai selisih antara intersep dari suatu unit crosssectional dan $\beta_{1}$ dinyatakan dalam random error $\varepsilon_{i}$ (Gujarati, 2003:647).

Dengan mensubstitusikan [3.4] ke dalam [3.2], maka diperoleh

$$
\begin{gathered}
\text { Pengeluaran }_{i, t}=\beta_{1 i}+\beta_{2} \text { Pendapatan }_{i, t}+u_{i, t} \\
\text { Pengeluaran }_{i, t}=\beta_{1}+\beta_{2} \text { Pendapatan }_{i, t}+\varepsilon_{i}+u_{i, t} \\
\text { Pengeluaran }_{i, t}=\beta_{1}+\beta_{2} \text { Pendapatan }_{i, t}+w_{i, t},
\end{gathered}
$$

di mana

$$
w_{i, t}=\varepsilon_{i}+u_{i, t} \cdot[3.5]
$$

Perhatikan bahwa $w_{i, t}$ disebut juga dengan istilah composite error (kesalahan gabungan), yang mana terdiri dari dua komponen (component), yakni $\varepsilon_{i}$ merupakan cross-sectional error component, dan $u_{i, t}$ merupakan combined time series dan cross-sectional error component. Istilah mengenai error 
components model (ECM) mengacu pada composite error $w_{i, t}$ terdiri dari dua (atau lebih) error components (Gujarati, 2003:648).

Gujarati (2003:648) memaparkan asumsi-asumsi dari ECM sebagai berikut.

$$
\begin{gathered}
\varepsilon_{i} \sim N\left(0, \sigma_{\varepsilon}^{2}\right) \\
u_{i, t} \sim N\left(0, \sigma_{u}^{2}\right) \\
E\left(\varepsilon_{i}, u_{i, t}\right)=0, \quad E\left(\varepsilon_{i}, \varepsilon_{j}\right)=0, \quad(i \neq j) \\
E\left(u_{i, t}, u_{i, s}\right)=E\left(u_{i, t}, u_{j, t}\right)=E\left(u_{i, t}, u_{j, s}\right)=0, \quad(i \neq j ; t \neq s) .
\end{gathered}
$$

Perhatikan bahwa pada asumsi $\varepsilon_{i} \sim N\left(0, \sigma_{\varepsilon}^{2}\right)$ berarti error component $\varepsilon_{i}$ diasumsikan berdistribusi normal dengan rata-rata 0 dan varians $\sigma_{\varepsilon}^{2}$. Pada asumsi $u_{i, t} \sim N\left(0, \sigma_{u}^{2}\right)$ berarti error component $u_{i, t}$ diasumsikan berdistribusi normal dengan rata-rata 0 dan varians $\sigma_{u}^{2}$. Sementara pada asumsi $E\left(\varepsilon_{i}, u_{i, t}\right)=$ 0 berarti antara error component $\varepsilon_{i}$ dan error component $u_{i, t}$ tidak berkorelasi (uncorrelated), serta $E\left(\varepsilon_{i}, \varepsilon_{j}\right)=0$ berarti antara error component $\varepsilon_{i}$ dan $\varepsilon_{j}$, dengan $i \neq j$, tidak berkorelasi.

Perlu diperhatikan bahwa dalam FEM, setiap unit cross-sectional memiliki nilai intersepnya masing-masing, yakni dalam $N$ nilai-nilai tertentu (in all $N$ such values), untuk $N$ unit cross-sectional, sedangkan dalam ECM, intersep $\beta_{1}$ menyatakan nilai rata-rata dari seluruh nilai intersep unit cross-sectional dan error component $\varepsilon_{i}$ menyatakan penyimpangan nilai intersep dari suatu crosssectional terhadap $\beta_{1}$. Perlu diperhatikan juga bahwa nila $\varepsilon_{i}$ tidak dapat diobservasi secara langsung, yang mana dikenal dengan istilah unobservable, atau latent variable (Gujarati, 2003:648).

\section{Pemilihan Model antara $\mathcal{F E M}$ (Fixed $\mathcal{E} f f e c t s$ Model) dan CEM (Common Iffects Model)}

Uji $F$ dapat digunakan dalam pemilihan model antara CEM dan FEM. Berikut rumus untuk menghitung nilai statistik dari uji F (Baltagi, 2011:308).

$$
F=\frac{\left(\frac{(R R S S-U R S S)}{(N-1)}\right)}{\left(\frac{U R S S}{N T-N-K}\right)}
$$

Perhatikan bahwa RRSS merupakan restricted residuals sums of squares, URSS merupakan unrestricted residuals sums of squares, $\mathrm{N}$ merupakan jumlah unit cross-sectional, T merupakan jumlah waktu pengamatan, dan $K$ jumlah 
variabel bebas yang digunakan. Dengan kata lain, RRSS merupakan residual sums of squares dari CEM, sedangkan URSS merupakan residual sums of squares dari FEM. Selanjutnya nilai statistik dari uji $\mathrm{F}$ dibandingkan dengan nilai kritis F (F tabel). Sebelum menentukan nilai kritis F, maka perlu ditentukan nilai derajat bebas pembilang (numerator) dan derajat bebas penyebut (denominator). Nilai derajat bebas pembilang dan penyebut ditentukan sebagai berikut.

$$
\begin{gathered}
d f 1=\text { derajat bebas pembilang }=N-1 . \\
d f 2=\text { derajat bebas penyebut }=N T-N-K .
\end{gathered}
$$

Jika nilai statistik dari uji $F$ lebih besar atau sama dengan nilai kritis $F$ ( $F_{\text {hitung }} \geq F_{\text {kritis }}$ ), maka FEM lebih baik dibandingkan CEM. Cara lain adalah dengan membandingkan nilai probabilitas (probability) terhadap tingkat signifikansi. Jika nilai probabilitas lebih kecil dibandingkan tingkat signifikansi, maka FEM lebih baik dibandingkan CEM.

Cara lain untuk menghitung nilai statistik dari uji $F$ adalah sebagai berikut (Gujarati, 2003:643).

$$
F=\frac{\left(\frac{R_{U R}^{2}-R_{R}^{2}}{N-1}\right)}{\left(\frac{1-R_{U R}^{2}}{N T-N-K}\right)}
$$

Perhatikan bahwa $R_{U R}^{2}$ dan $R_{R}^{2}$ masing-masing merupakan nilai koefisien determinasi unrestricted dan restricted. Dengan kata lain, $R_{U R}^{2}$ merupakan nilai koefisien determinasi dari FEM, sedangkan $R_{R}^{2}$ nilai koefisien determinasi dari CEM. Penghitungan nilai kritis $F$ sama seperti sebelumnya.

\section{Pemilihan $\mathcal{M}$ odel antara $\mathcal{F E M}$ (Fixed $\mathcal{E}$ ffects $\mathcal{M}$ odel) dan ECM (Error Component Model)}

Judge (1980) dalam Gujarati (2003:650) memberikan saran dalam pemilihan model antara FEM dan ECM sebagai berikut.

1. Jika jumlah waktu pengamatan $(T)$ panjang atau besar (large) dan jumlah unit cross-sectional $(N)$ sedikit atau kecil (small), terdapat perbedaan yang tipis (there is likely to be little difference) pada nilainilai estimasi parameter antara FEM dan ECM. Namun dalam hal ini, FEM mungkin lebih disukai.

2. Ketika jumlah unit cross-sectional $(N)$ banyak dan jumlah waktu pengamatan $(T)$ pendek, estimasi-estimasi parameter yang diperoleh antara FEM dan ECM dapat berbeda signifikan. Ingat kembali bahwa pada ECM, $\beta_{1 i}=\beta_{1}+\varepsilon_{i}$, di mana $\varepsilon_{i}$ merupakan cross-sectional 
random component, sedangkan dalam FEM, $\beta_{1 i}$ diperlakukan tetap (treat $\beta_{1 i}$ as fixed) dan tidak acak. Pada kasus ini, penentuan FEM dan ECM bergantung pada unit-unit cross-sectional yang diamati dalam sampel. Jika sangat yakin bahwa individu-individu atau unit-unit cross-sectional dalam sampel tidak berdasarkan pengambilan atau penarikkan acak (are not random drawing), maka FEM lebih cocok. Namun jika unit-unit cross-sectional dalam sampel berdasarkan pengambilan acak (random drawings), maka ECM lebih cocok.

3. Jika cross-sectional error component $\varepsilon_{i}$ dan satu atau lebih variabel bebas berkorelasi, maka estimator-estimator pada ECM bias (biased), sedangkan estimator-estimator pada FEM tak bias (unbiased).

4. Jika jumlah unit cross-sectional $(N)$ banyak dan jumlah waktu pengamatan $(T)$ pendek, dan jika asumsi-asumsi yang mendasari ECM terpenuhi, maka estimator-estimator ECM lebih efisien dibandingkan estimator-estimator FEM.

Terdapat juga uji formal (formal test) dalam pemilihan model antara FEM dan ECM. Terpenuhinya atau tidak asumsi mengenai korelasi antara individual (cross-sectional) error component $\varepsilon_{i}$ terhadap variabel-variabel bebas, menentukan dalam pemilihan model antara FEM dan ECM. Gujarati (2003:650) menyatakan sebagai berikut.

"The challenge facing a researcher is: Which model is better, FEM or ECM? The answer to this question hinges around the assumption one makes about the likely correlation between the individual, or cross-section specific, error component $\varepsilon_{i}$ and the $X$ regressors".

Senada dengan Gujarati, Baltagi (2011:320) menyatakan sebagai berikut.

"A critical assumption in the error components regression model is that $E\left(u_{i t} / X_{i t}\right)=0$. This is important given that the disturbances contain individual effects which are unobserved and may be correlated with the $X_{i t}{ }^{\prime} s$ ".

Johnston dan DiNardo (1996:403-404) menyatakan sebagai berikut.

"We have developed two estimators that have different properties depending on the correlation between $\alpha_{i}$ and the regressors. Specifically.

1. If the effects are uncorrelated with the explanatory variables, the random effects (RE) estimator is consistent and efficient. The fixed effects (FE) estimator is consistent but not efficient.

2. If the effects are correlated with the explanatory variables, the fixed effects estimator is consistent and efficient but the random effects estimator is now inconsistent". 
Uji Hausman dapat digunakan dalam penentuan model antara FEM dan ECM. Hipotesis nol menyatakan estimator-estimator antara FEM dan ECM tidak berbeda secara substansial. Dengan kata lain, jika hipotesis nol ditolak, maka ECM tidak cocok untuk digunakan, dan lebih baik menggunakan FEM (Gujarati, 2003:651). Nilai statistik dari uji Hausman secara asimtotik berdistribusi chi-kuadrat dengan derajat bebas $k$, di mana $k$ merupakan jumlah variabel bebas, dengan hipotesis nol menyatakan random effects estimator benar. Johnston dan DiNardo (1996:404) menyatakan sebagai berikut.

"The Hausman test statistic (discussed in Chapter 10) will be distributed as $\chi^{2}$ with $k$ degrees of freedom under the null hypothesis that the random effects estimator is correct". 


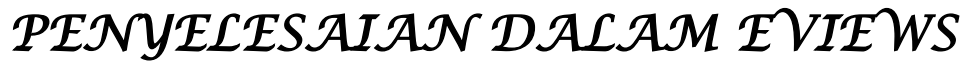

Misalkan diberikan data panel sebagai berikut (Tabel 3.1).

Tabel 3.1 Data Pendapatan dan Pengeluaran (Dalam Milyar)

(Data Fiktif)

\begin{tabular}{|c|c|c|c|}
\hline Perusahaan & Tahun & Pengeluaran & Pendapatan \\
\hline Perusahaan A & 2000 & 2.1 & 4 \\
\hline Perusahaan A & 2001 & 2.3 & 5.4 \\
\hline Perusahaan A & 2002 & 2.2 & 2.7 \\
\hline Perusahaan A & 2003 & 2.4 & 6.8 \\
\hline Perusahaan A & 2004 & 2.2 & 3.4 \\
\hline Perusahaan B & 2000 & 3.4 & 10.4 \\
\hline Perusahaan B & 2001 & 3 & 4.3 \\
\hline Perusahaan B & 2002 & 3.2 & 9 \\
\hline Perusahaan B & 2003 & 3.3 & 8.5 \\
\hline Perusahaan B & 2004 & 3.2 & 4.5 \\
\hline Perusahaan C & 2000 & 5.5 & 7 \\
\hline Perusahaan C & 2001 & 5.4 & 6.3 \\
\hline Perusahaan C & 2002 & 5.5 & 6 \\
\hline Perusahaan C & 2003 & 5.2 & 5.6 \\
\hline Perusahaan C & 2004 & 5.3 & 5.6 \\
\hline
\end{tabular}

Berdasarkan Tabel 3.1, diketahui terdapat tiga perusahaan, dengan masingmasing perusahaan diamati pendapatan dan pengeluaran selama 5 tahun, yakni dari tahun 2000 hingga 2004. Tahap awal untuk mengolah data tersebut dalam EViews ialah ketik data pada Tabel 3.1 seperti pada Gambar 3.1. Selanjutnya simpan dengan nama data panel baru dengan format Excel 97-2003 Workbook $(* . x l s)$. 


\section{Gambar 3.1}

\begin{tabular}{|c|c|c|}
\hline \multicolumn{2}{|c|}{ Clipboard } & \multicolumn{2}{|c|}{ Font } \\
\hline \hline & A2 & $f_{x}$ \\
\hline & A & B \\
\hline \hline 1 & Pengeluaran & Pendapatan \\
\hline 2 & 2.1 & 4 \\
\hline 3 & 2.3 & 5.4 \\
\hline 4 & 2.2 & 2.7 \\
\hline 5 & 2.4 & 6.8 \\
\hline 6 & 2.2 & 3.4 \\
\hline 7 & 3.4 & 10.4 \\
\hline 8 & 3 & 4.3 \\
\hline 9 & 3.2 & 9 \\
\hline 10 & 3.3 & 8.5 \\
\hline 11 & 3.2 & 4.5 \\
\hline 12 & 5.5 & 7 \\
\hline 13 & 5.4 & 6.3 \\
\hline 14 & 5.5 & 6 \\
\hline 15 & 5.2 & 5.6 \\
\hline 16 & 5.3 & 5.6 \\
\hline
\end{tabular}

\section{Save As}

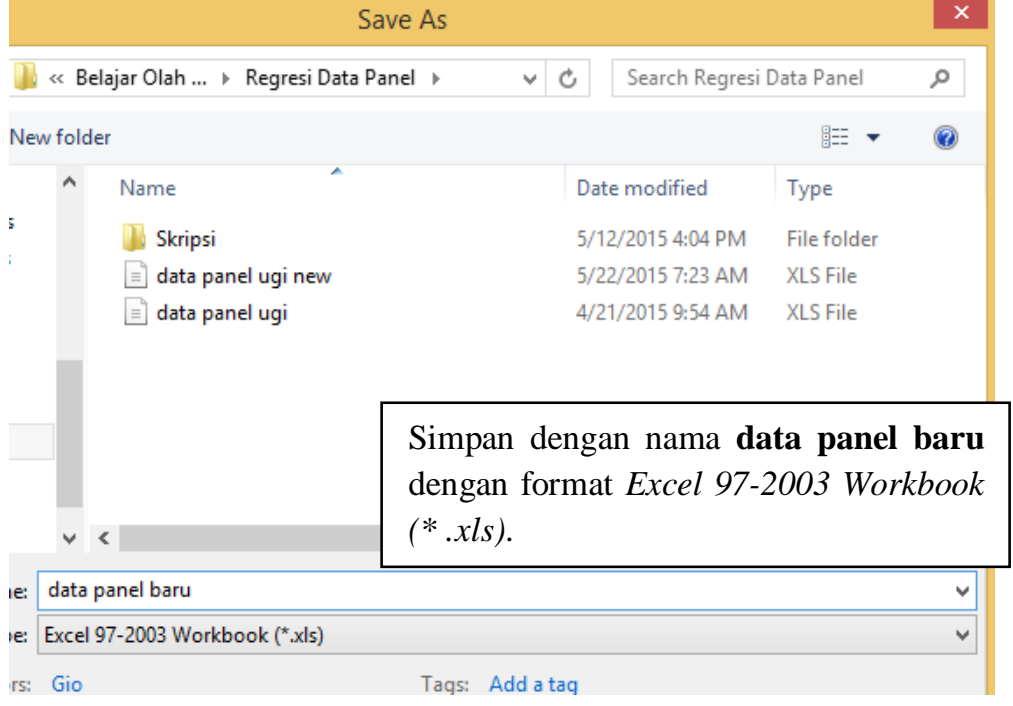

Selanjutnya aktifkan Software EViews 7. Pilih File $\Rightarrow$ New $\Rightarrow$ Workfile... (Gambar 3.1), sehingga muncul kotak Workfile Create (Gambar 3.2). 


\section{Gambar 3.2}

घ. EViews
\begin{tabular}{|l|l|l|}
\hline File Edit Object View Proc Quick Options Window Help \\
\hline New & Ctrl+S & Dorkfle... \\
\hline Open & & Program \\
Save & Iext File \\
\hline Save As... & & \\
\hline Close & & \\
\hline
\end{tabular}

Pada Gambar 3.3, ketik 2000 pada Start date: dan pada End date: ketik 2004. Hal ini karena waktu pengamatan (time series) dimulai dari tahun 2000 hingga 2004. Selanjutnya pilih OK, sehingga muncul kotak Workfile: UNTITLED (Gambar 3.4). Pada Gambar 3.4, pilih Object $=>$ New Object..., sehingga muncul kotak New Object (Gambar 3.5).

\section{Gambar 3.3}

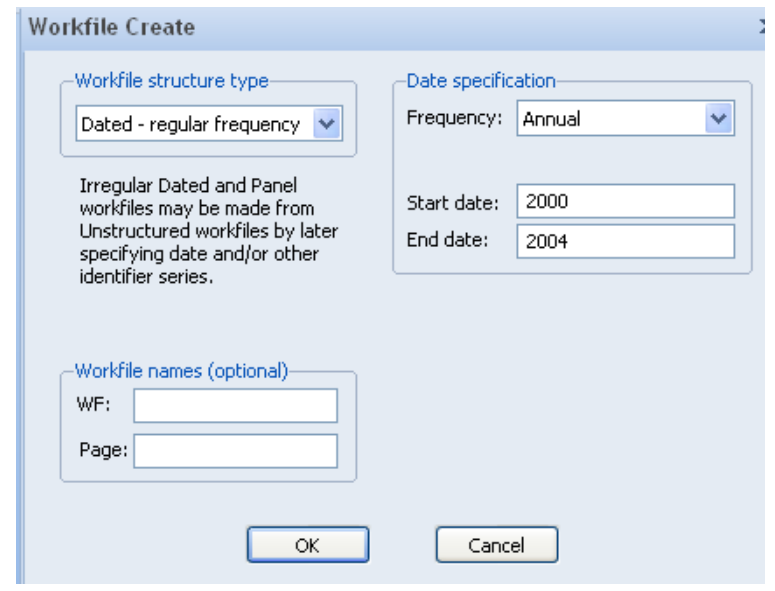

Pada Gambar 3.5, pilih Pool pada Type of object, dan ketik Ugi pada Name of object. Kemudian pilih OK, sehingga muncul kotak Pool: UGI (Gambar 3.6). Pada Gambar 3.6, ketik seperti berikut.

\section{_PerusahaanA _PerusahaanB _PerusahaanC}

Perhatikan bahwa terdapat 3 perusahaan, yakni perusahaan A, B, dan C. 


\section{Gambar 3.4}

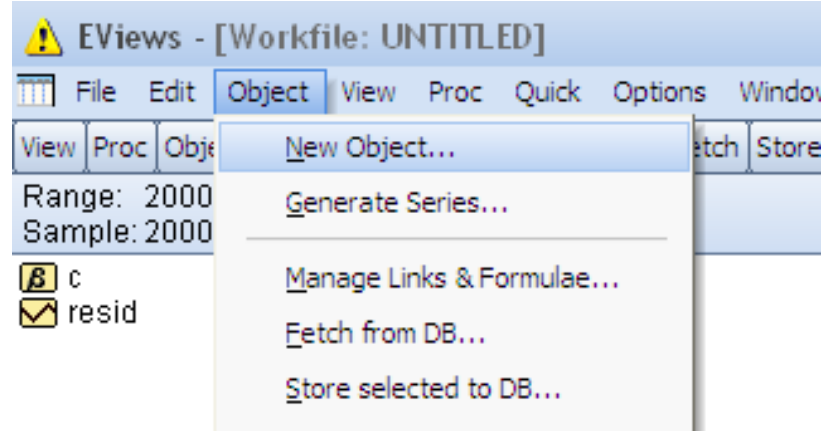

Gambar 3.5

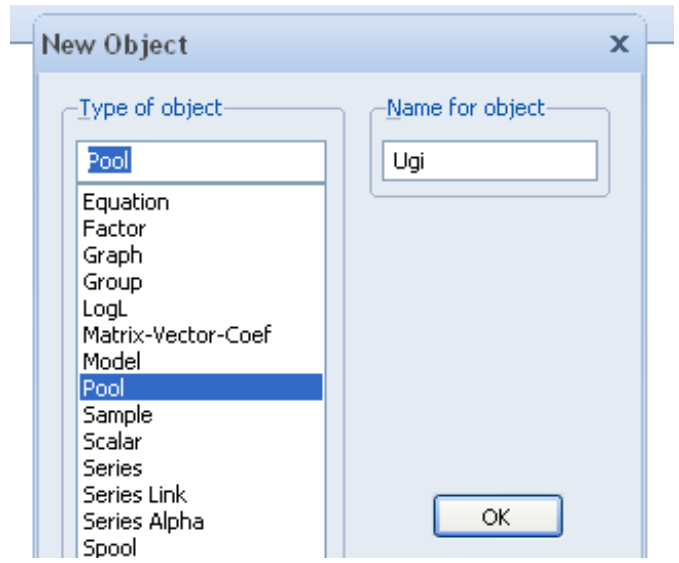

Pada Gambar 3.6 atau Gambar 3.7, pilih Proc => Import Pool Data (ASCII, $X L S, W K$ ?), sehingga muncul kotak Open (Gambar 3.8).

\section{Gambar 3.6}

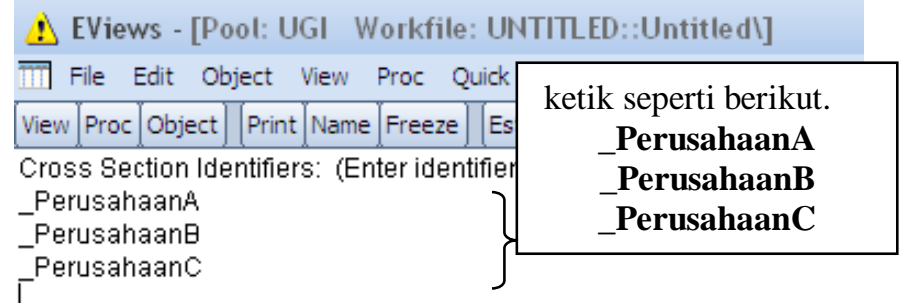

Gambar 3.7 


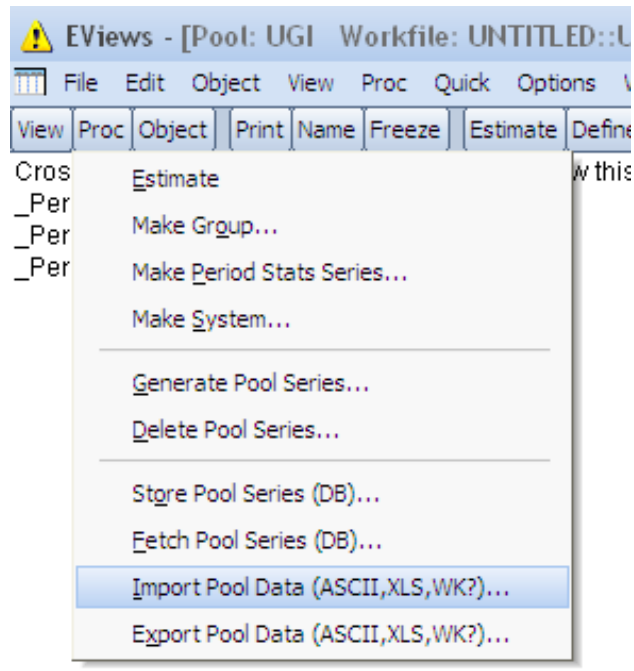

Pada kotak Open (Gambar 3.7), pilih file Excel (format 97-2003) bernama data panel ugi dan pilih Open, sehingga muncul kotak Excel Spreadsheet Import (Gambar 3.8). Pada Gambar 3.8, pilih file Excel yang telah disimpan tadi, dengan nama data panel baru.

\section{Gambar 3.8}

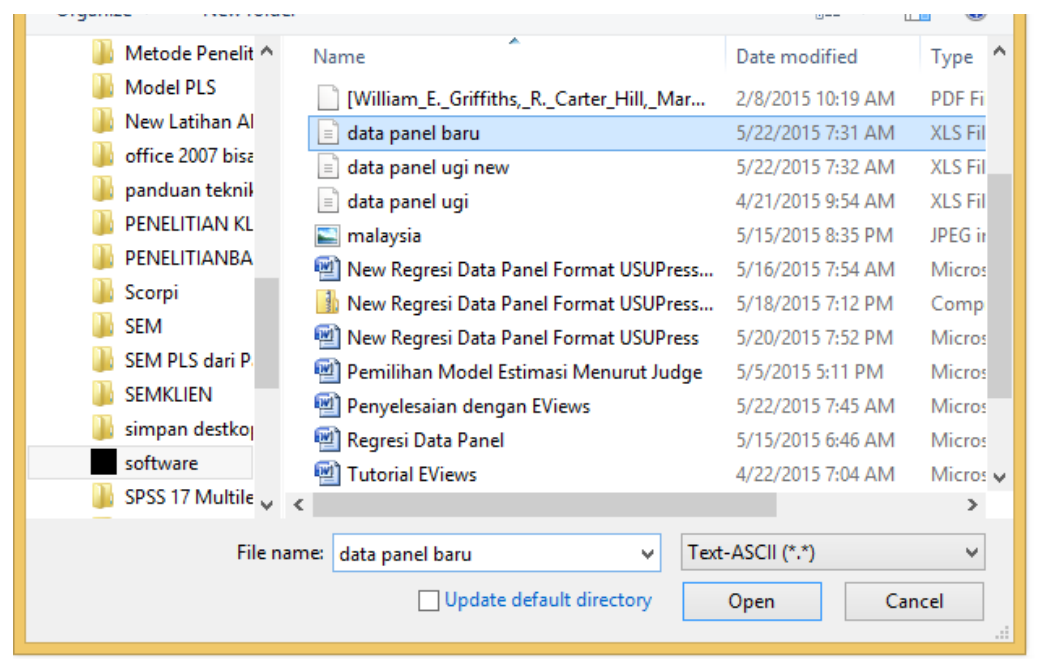

Pada Gambar 3.9, ketik A2 pada bagian Upper-left data cell. Mengapa A2??? Perhatikan Gambar 3.10. Pada Gambar 3.9, yakni pada Ordinary and Pool 
(specified with ?) series to read, masukkan nama-nama variabel, dengan mengakhiri nama variabel dengan tanda Tanya “?”.

\section{Pengeluaran? Pendapatan?}

\section{Catatan: Nama variabel diakhiri dengan tanda tanya "?".}

Kemudian pilih $O K$, hasilnya seperti pada Gambar 3.11.

Pada Gambar 3.12, yakni pada Dependent variable, ketik Pengeluaran? sebagai variabel tak bebas. Pada Common coefficients: ketik Pendapatan? Dan C. C dalam hal ini merupakan konstanta dari persamaan regresi. Kemudian pilih OK. Sehingga diperoleh common effects models (CEM).

\section{Gambar 3.9}

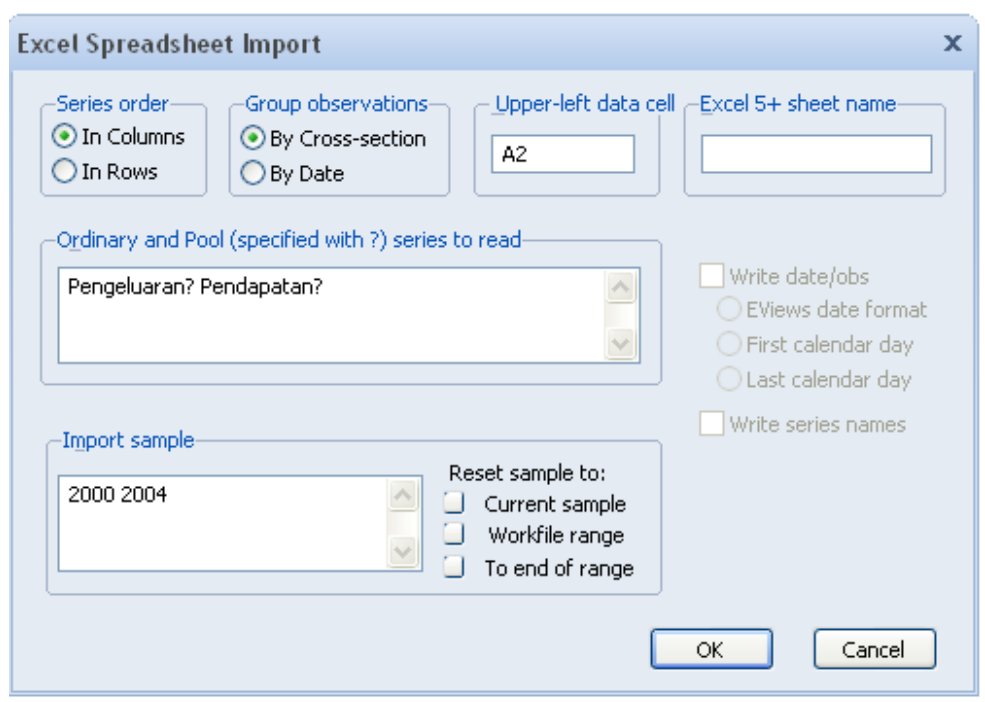


Gambar 3.10

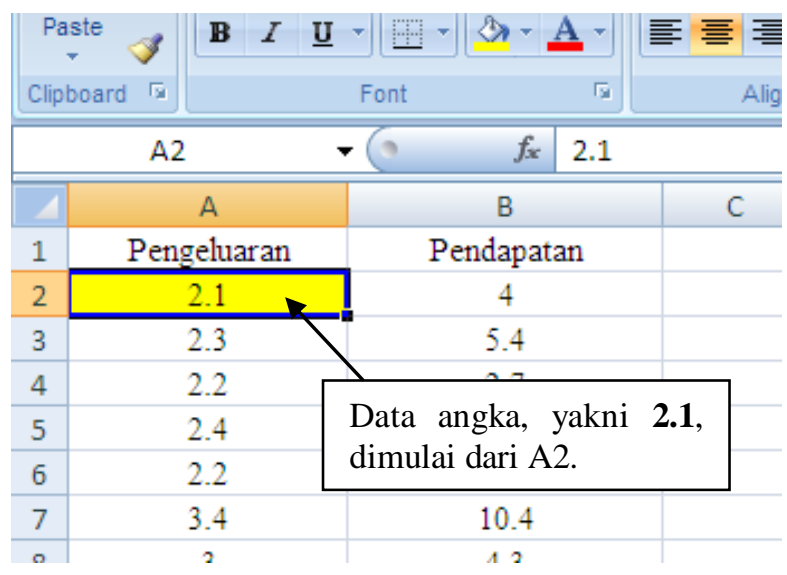

Pada Gambar 3.11, pilih Estimate, sehingga muncul kotak Pool Estimation (Gambar 3.12).

\section{Gambar 3.11}

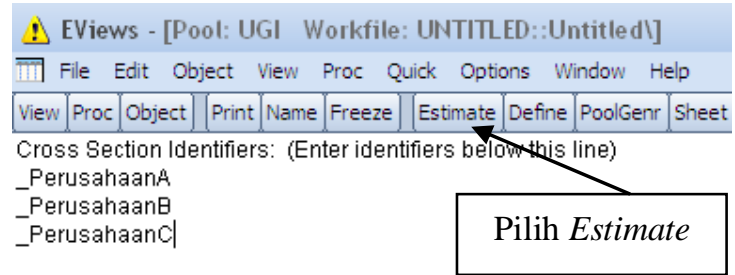

\section{Gambar 3.12}

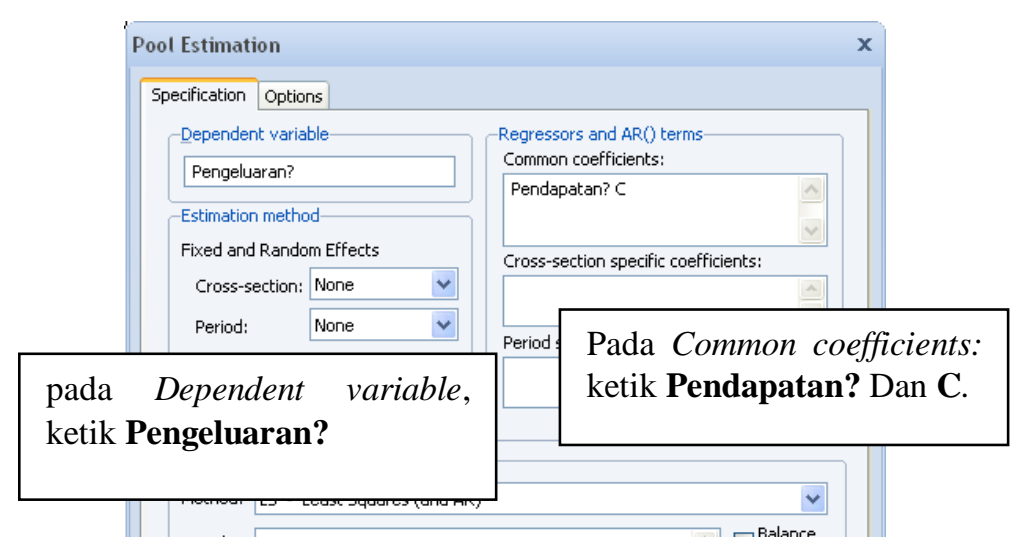


Pada Gambar 3.12, ketik Pengeluaran? pada kotak Dependent variable? Dan ketik Pendapatan? C pada kotak Common coefficients: Kemudian pilih OK., sehingga diperoleh common effects model, seperti pada Tabel 3.2.

\section{Common Effects Model}

Tabel 3.2 Hasil Berdasarkan Common Effects Model

Dependent Variable: PENGELUARAN?

Method: Pooled Least Squares

Date: 04/21/15 Time: 10:03

Sample: 20002004

Included observations: 5

Cross-sections included: 3

Total pool (balanced) observations: 15

\begin{tabular}{lrlrr}
\hline \hline \multicolumn{1}{c}{ Variable } & Coefficient & \multicolumn{1}{c}{ Std. Error } & t-Statistic & Prob. \\
\hline \hline \multicolumn{1}{c}{ PENDAPATAN? } & 0.172380 & 0.170547 & 1.010743 & 0.3306 \\
\multicolumn{1}{c}{ C } & 2.584802 & 1.076666 & 2.400747 & 0.0320 \\
\hline \hline R-squared & 0.072859 & Mean dependent var & 3.613333 \\
Adjusted R-squared & 0.001541 & S.D. dependent var & 1.363224 \\
S.E. of regression & 1.362174 & Akaike info criterion & 3.579607 \\
Sum squared resid & 24.12173 & Schwarz criterion & 3.674013 \\
Log likelihood & -24.84705 & Hannan-Quinn criter. & 3.578601 \\
F-statistic & 1.021602 & Durbin-Watson stat & 0.086433 \\
Prob(F-statistic) & 0.330583 & & \\
\hline \hline
\end{tabular}

Berdasarkan Tabel 3.2, diperoleh CEM sebagai berikut.

$$
\text { Pengeluaran }=2,58+0,17 \text { Pendapatan } .
$$

Diketahui pengaruh variabel bebas pendapatan terhadap pengeluaran tidak signifikan secara statistik pada tingkat signifikansi 0,05 . Hal ini karena nilai Prob. dari variabel pendapatan, yakni 0,3306 lebih besar dari 0,05.

Selanjutnya pilih Estimate (Gambar 3.13), sehingga muncul kotak Pool Estimation (Gambar 3.14). Pada Cross-section, atur menjadi Fixed (Gambar 3.14). Kemudian pilih OK, sehingga diperoleh FEM (Tabel 3.3).

\section{Gambar 3.13}


1) EViews - [Pool: UGI Workfile: UNTITLED::UntitledI]

77] File Edit Object View Proc Quick Options Window Help View Proc Object] [Print Name Freeze] [Estimate [Define PoolGenr [Sheet

Dependent Variable: PENGELUARAN?

Method: Pooled Least Squares

Date: 04/21/15 Time: 10:03

Sample: 20002004

Included observations: 5

Cross-sections included: 3

Total pool (balanced) observations: 15

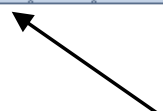

Pilih Estimate

\begin{tabular}{lrllc}
\hline \hline \multicolumn{1}{c}{ Variable } & Coefficient & Std. Error & t-Statistic & Prob. \\
\hline \hline \multicolumn{1}{c}{ PENDAPATAN? } & 0.172380 & 0.170547 & 1.010743 & 0.3306 \\
\multicolumn{1}{c}{ C } & 2.584802 & 1.076666 & 2.400747 & 0.0320 \\
\hline \hline R-squared & 0.072859 & Mean dependent var & 3.613333 \\
Adjusted R-squared & 0.001541 & S.D. dependent var & 1.363224 \\
S.E. of regression & 1.362174 & Akaike info criterion & 3.579607 \\
Sum squared resid & 24.12173 & Schwarz criterion & 3.674013 \\
Log likelihood & -24.84705 & Hannan-Quinn criter. & 3.578601 \\
F-statistic & 1.021602 & Durbin-Watson stat & 0.086433 \\
Prob(F-statistic) & 0.330583 & & & \\
& & & & \\
& & & &
\end{tabular}

Gambar 3.14

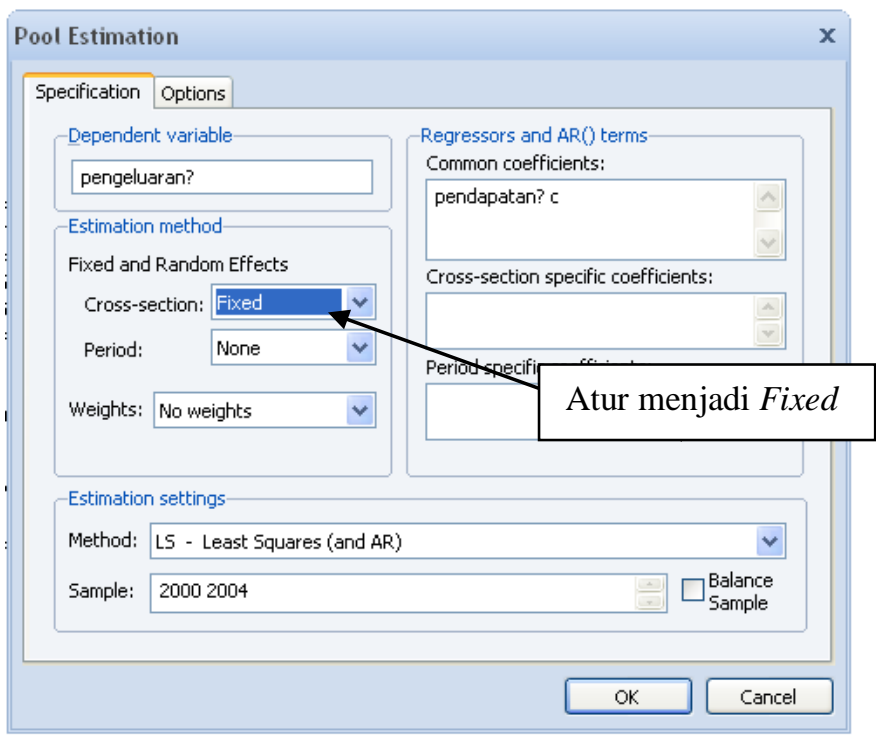

Tabel 3.3 Hasil Berdasarkan Fixed Effects Model 
Dependent Variable: PENGELUARAN?

Method: Pooled Least Squares

Date: 04/21/15 Time: 10:04

Sample: 20002004

Included observations: 5

Cross-sections included: 3

Total pool (balanced) observations: 15

\begin{tabular}{ccccc}
\hline \hline Variable & Coefficient & Std. Error & t-Statistic & Prob. \\
\hline \hline PENDAPATAN? & 0.050648 & 0.014399 & 3.517485 & 0.0048 \\
C & 3.311136 & 0.089299 & 37.07916 & 0.0000 \\
Fixed Effects (Cross) & & & & \\
_PERUSAHAANA--C & -1.297024 & & & \\
_PERUSAHAANB--C & -0.462889 & & & \\
_PERUSAHAANC--C & 1.759914 & & & \\
\hline \hline
\end{tabular}

Effects Specification

Cross-section fixed (dummy variables)

\begin{tabular}{lllr}
\hline \hline R-squared & 0.996237 & Mean dependent var & 3.613333 \\
Adjusted R-squared & 0.995211 & S.D. dependent var & 1.363224 \\
S.E. of regression & 0.094336 & Akaike info criterion & -1.660730 \\
Sum squared resid & 0.097892 & Schwarz criterion & -1.471917 \\
Log likelihood & 16.45548 & Hannan-Quinn criter. & -1.662742 \\
F-statistic & 970.8450 & Durbin-Watson stat & 1.891874 \\
Prob(F-statistic) & 0.000000 & & \\
\hline \hline
\end{tabular}

Berdasarkan Tabel 3.3, akan ditentukan FEM sebagai berikut.

$$
\begin{gathered}
3,311136-1,297024=2,014112 \\
3,311136-0,462889=2,848247 \\
2,848247=2,014112+\mathbf{0 , 8 3 4 1 3 5} \\
3,311136+1,759914=5,07105 \\
5,07105=2,014112+\mathbf{3}, \mathbf{0 5 6 9 3 8}
\end{gathered}
$$

Sehingga diperoleh FEM sebagai berikut.

$$
\begin{aligned}
\text { Pengeluaran }= & 2.014112+0,834135 D_{2}+3,056938 D_{3} \\
& +0,050648 \text { Pendapatan } .
\end{aligned}
$$


Diketahui pengaruh variabel bebas pendapatan terhadap pengeluaran pada FEM signifikan secara statistik pada tingkat signifikansi 0,05 . Hal ini karena nilai Prob. dari variabel pendapatan, yakni 0,0048 lebih kecil dari 0,05.

Diketahui bahwa pada CEM, pengaruh variabel pendapatan terhadap pengeluaran tidak signifikan pada tingkat signifikansi 0,05 , sedangkan pada FEM signifikan pada tingkat signifikansi 0,05.

\section{Pemilihan Model antara $\mathcal{F E M}$ (Fixed Effects Model) dan CEM (Common Iffects Model)}

Diketahui RRSS $=24,12173$, URSS $=0,097892, \mathrm{~N}=3, \mathrm{~T}=5$, dan $\mathrm{K}=1$. Berikut perhitungan untuk nilai statistik dari uji $F$.

$$
\begin{gathered}
F=\frac{\left(\frac{(R R S S-U R S S)}{(N-1)}\right)}{\left(\frac{U R S S}{N T-N-K}\right)}=\frac{\left(\frac{24,12173-0,097892}{3-1}\right)}{\left(\frac{0,097892}{15-3-1}\right)}=\frac{12,011919}{0,00889927} \\
F=1349,76453 .
\end{gathered}
$$

Selanjutnya nilai statistik dari uji $F$ dibandingkan dengan nilai kritis $F$ (F tabel). Sebelum menentukan nilai kritis $F$, maka perlu ditentukan nilai derajat bebas pembilang (numerator) dan derajat bebas penyebut (denominator). Nilai derajat bebas pembilang dan penyebut ditentukan sebagai berikut.

$$
\begin{gathered}
d f 1=\text { derajat bebas pembilang }=N-1=3-1=2 . \\
d f 2=\text { derajat bebas penyebut }=N T-N-K=11 .
\end{gathered}
$$

\section{Gambar 3.15}

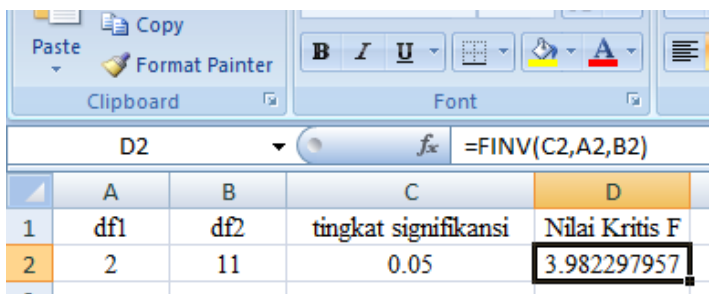

Berdasarkan perhitungan Microsoft Excel pada Gambar 3.15, diketahui nilai kritis $F$ adalah 3,98. Perhatikan bahwa karena nilai statistik dari uji $F$, yakni 
1349,76453 lebih besar dibandingkan nilai kritis $F$, yakni 3,98, maka disimpulkan bahwa FEM lebih baik dibandingkan CEM.

Dengan pendekatan probabilitas (probability approach), diketahui nilai probabilitas dari nilai statistik dari uji $F$ adalah 0,000 (Tabel 3.4). Karena nilai probabilitas tersebut lebih kecil dari tingkat signifikansi 0,05, maka disimpulkan bahwa FEM lebih baik dibandingkan CEM.

Berikut langkah-langkah dalam EViews 7 untuk pengujian dalam pemilihan model antara FEM dan CEM. Pada Gambar 3.17, pilih View $=>$ Fixed/Random Effects Testing $\Rightarrow$ Redundant Fixed Effects - Likelihood Ratio, sehingga diperoleh hasil seperti pada Tabel 3.4.

\section{Gambar 3.16}

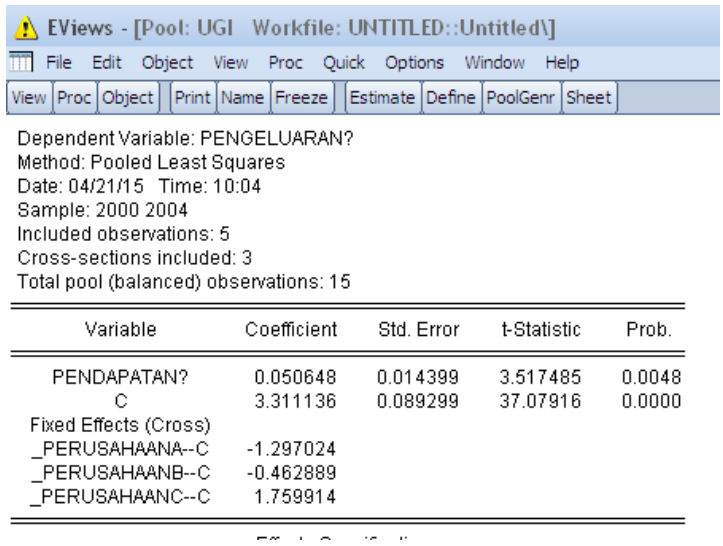

\section{Gambar 3.17}

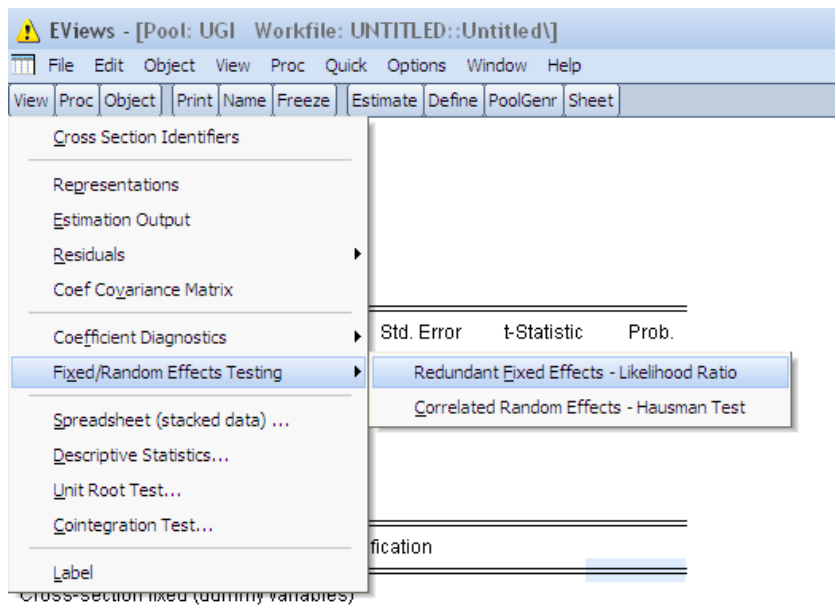




\section{Tabel 3.4 Hasil Pengujian antara FEM dan CEM}

Redundant Fixed Effects Tests

Pool: UGI

Test cross-section fixed effects

\begin{tabular}{lrrr}
\hline \hline Effects Test & Statistic & d.f. & Prob. \\
\hline \hline Cross-section F & 1349.764341 & $(2,11)$ & 0.0000 \\
Cross-section Chi-square & 82.605056 & 2 & 0.0000 \\
\hline \hline
\end{tabular}

Cross-section fixed effects test equation:

Dependent Variable: PENGELUARAN?

Method: Panel Least Squares

Date: 04/21/15 Time: 10:05

Sample: 20002004

Included observations: 5

Cross-sections included: 3

Total pool (balanced) observations: 15

\begin{tabular}{lrccr}
\hline \hline \multicolumn{1}{c}{ Variable } & Coefficient & Std. Error & t-Statistic & Prob. \\
\hline \hline \multicolumn{1}{c}{ PENDAPATAN? } & 0.172380 & 0.170547 & 1.010743 & 0.3306 \\
\multicolumn{1}{c}{ C } & 2.584802 & 1.076666 & 2.400747 & 0.0320 \\
\hline \hline R-squared & 0.072859 & Mean dependent var & 3.613333 \\
Adjusted R-squared & 0.001541 & S.D. dependent var & 1.363224 \\
S.E. of regression & 1.362174 & Akaike info criterion & 3.579607 \\
Sum squared resid & 24.12173 & Schwarz criterion & 3.674013 \\
Log likelihood & -24.84705 & Hannan-Quinn criter. & 3.578601 \\
F-statistic & 1.021602 & Durbin-Watson stat & 0.086433 \\
Prob(F-statistic) & 0.330583 & & \\
\hline \hline
\end{tabular}

Berdasarkan Tabel 3.4, diketahui nilai Cross-section $F$ adalah 1349,764341, di mana merupakan nilai statistik dari uji $F$.

\section{Pemilihan Model antara FEM (Fixed Effects Model) dan REM (Random Effects $\mathcal{M}$ odel)}

Berikut langkah-langkah dalam EViews 7 untuk pengujian dalam pemilihan model antara FEM dan REM. Pada Gambar 3.18, pilih Estimate, sehingga muncul kotak Pool Estimation (Gambar 3.19). 


\section{Gambar 3.18}

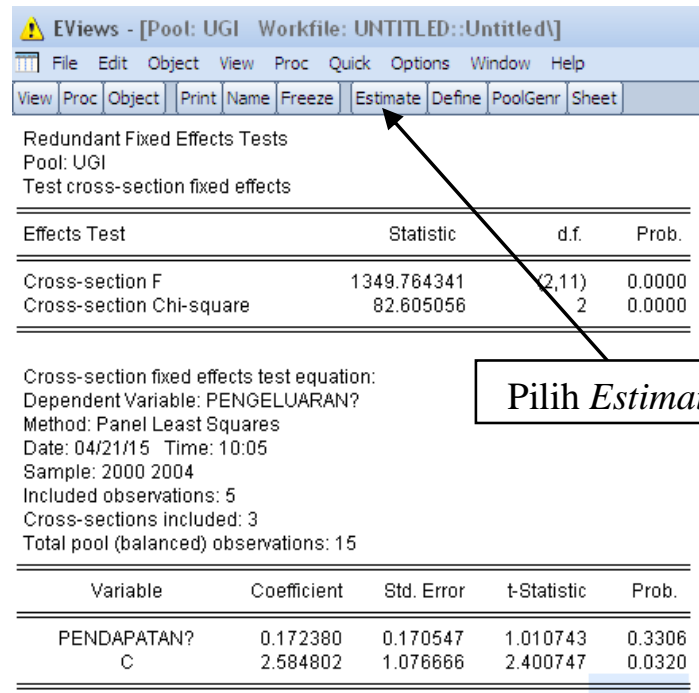

\section{Gambar 3.19}

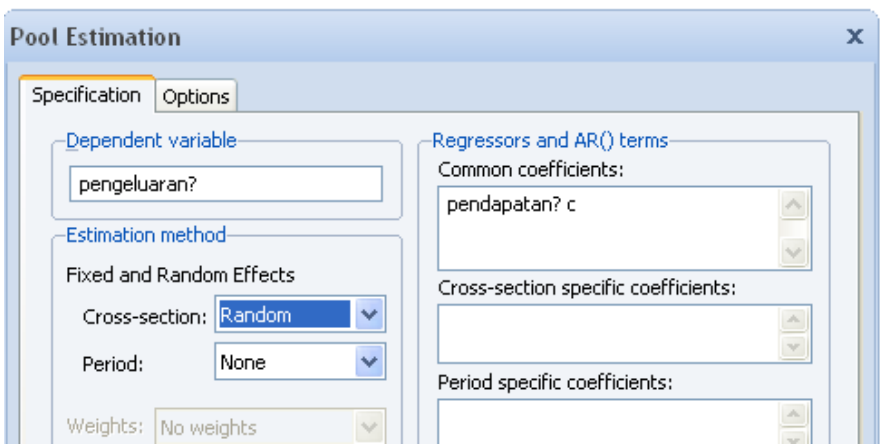

Pada Gambar 3.19, pilih Random pada Cross-section:, sehingga diperoleh REM pada Tabel 3.5. pada Gambar 3.20 pilih View $=>$ Fixed/Random Effects Testing $\Rightarrow$ Correlated Random Effects - Hausman Test (Gambar 3.21), hasilnya seperti pada Tabel 3.6. 


\section{Tabel 3.5 Hasil Berdasarkan Random Effects Model}

\begin{tabular}{|c|c|c|c|c|}
\hline \multicolumn{4}{|c|}{ Dependent Variable: PENGELUARAN? } & \\
\hline \multicolumn{5}{|c|}{ Method: Pooled EGLS (Cross-section random effects) } \\
\hline \multicolumn{5}{|c|}{ Date: 04/21/15 Time: 10:06 } \\
\hline \multicolumn{5}{|l|}{ Sample: 20002004} \\
\hline \multicolumn{5}{|l|}{ Included observations: 5} \\
\hline \multicolumn{5}{|l|}{ Cross-sections included: 3} \\
\hline \multicolumn{5}{|c|}{ Total pool (balanced) observations: 15} \\
\hline \multicolumn{5}{|c|}{ Swamy and Arora estimator of component variances } \\
\hline Variable & Coefficient & Std. Error & t-Statistic & Prob. \\
\hline PENDAPATAN? & 0.050721 & 0.014397 & 3.522893 & 0.0037 \\
\hline $\mathrm{C}$ & 3.310701 & 1.216283 & 2.721981 & 0.0174 \\
\hline \multicolumn{5}{|l|}{ Random Effects (Cross) } \\
\hline PERUSAHAANA--C & -1.296392 & & & \\
\hline PERUSAHAANB--C & -0.462803 & & & \\
\hline \multirow[t]{4}{*}{ PERUSAHAANC--C } & 1.759195 & & & \\
\hline & & & & \\
\hline & Effects $\mathrm{Sp}$ & cification & & \\
\hline & & & S.D. & Rho \\
\hline & & & & \\
\hline \multicolumn{3}{|l|}{ Cross-section random } & 2.100980 & 0.9980 \\
\hline \multicolumn{3}{|l|}{ Idiosyncratic random } & 0.094336 & 0.0020 \\
\hline & & & & \\
\hline & \multicolumn{2}{|c|}{ Weighted Statistics } & & \\
\hline R-squared & 0.505703 & \multicolumn{2}{|c|}{ Mean dependent var } & 0.072542 \\
\hline Adjusted R-squared & 0.467680 & \multicolumn{2}{|c|}{ S.D. dependent var } & 0.124901 \\
\hline S.E. of regression & 0.091128 & \multicolumn{2}{|c|}{ Sum squared resid } & 0.107956 \\
\hline F-statistic & 13.29998 & \multicolumn{2}{|c|}{ Durbin-Watson stat } & 1.715252 \\
\hline \multirow[t]{2}{*}{ Prob(F-statistic) } & 0.002955 & & & \\
\hline & Unweighte & Statistics & & \\
\hline R-squared & 0.036568 & \multicolumn{2}{|c|}{ Mean dependent var } & 3.613333 \\
\hline Sum squared resid & 25.06593 & \multicolumn{2}{|c|}{ Durbin-Watson stat } & 0.007387 \\
\hline
\end{tabular}




\section{Gambar 3.20}

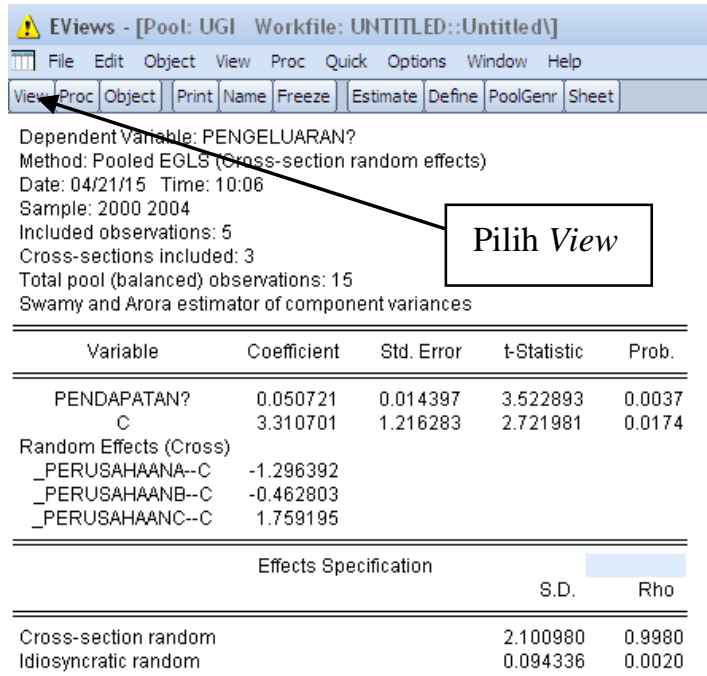

\section{Gambar 3.21}

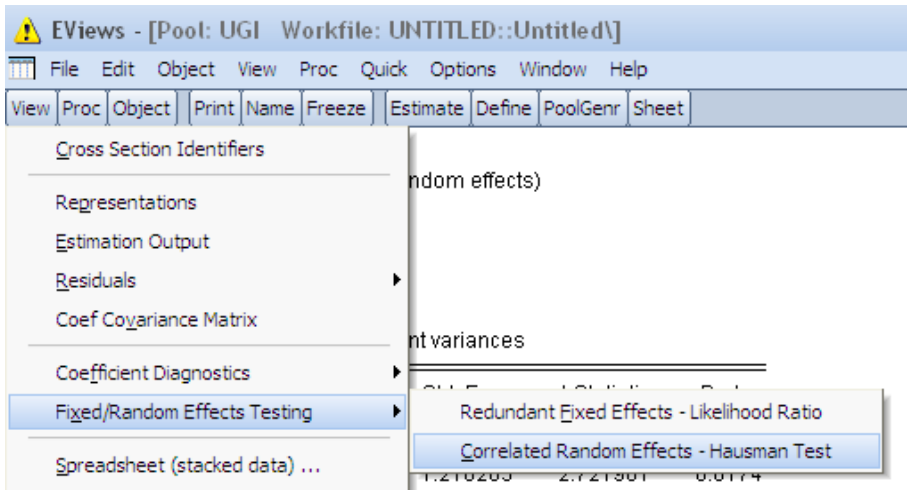




\section{Tabel 3.6 Hasil Pengujian antara FEM dan REM}

\begin{tabular}{|c|c|c|c|c|}
\hline \multicolumn{4}{|c|}{ Correlated Random Effects - Hausman Test } & \\
\hline \multicolumn{4}{|l|}{ Pool: UGI } & \\
\hline \multicolumn{5}{|c|}{ Test cross-section random effects } \\
\hline \multicolumn{2}{|l|}{ Test Summary } & Chi-Sq. Statistic & Chi-Sq. d.f. & Prob. \\
\hline \multirow{2}{*}{\multicolumn{2}{|c|}{ Cross-section random }} & & & \\
\hline & & 0.130851 & 1 & 0.7176 \\
\hline & & & & \\
\hline \multicolumn{5}{|c|}{ Cross-section random effects test comparisons: } \\
\hline \multirow{2}{*}{\begin{tabular}{|l|} 
Variable \\
\end{tabular}} & & & & \\
\hline & Fixed & Random & $\operatorname{Var}($ Diff.) & Prob. \\
\hline \multirow[t]{2}{*}{ PENDAPATAN? } & 0.050648 & 0.050721 & 0.000000 & 0.7176 \\
\hline & & & & \\
\hline \multicolumn{5}{|c|}{ Cross-section random effects test equation: } \\
\hline \multicolumn{4}{|c|}{ Dependent Variable: PENGELUARAN? } & \\
\hline \multicolumn{3}{|c|}{ Method: Panel Least Squares } & & \\
\hline \multicolumn{5}{|c|}{ Date: 04/21/15 Time: 10:07 } \\
\hline \multicolumn{5}{|l|}{ Sample: 20002004} \\
\hline \multicolumn{5}{|l|}{ Included observations: 5} \\
\hline \multicolumn{5}{|c|}{ Cross-sections included: 3} \\
\hline \multicolumn{5}{|c|}{ Total pool (balanced) observations: 15} \\
\hline \multirow{2}{*}{\begin{tabular}{|l} 
Variable \\
\end{tabular}} & Coefficient & Std. Error & t-Statistic & Prob. \\
\hline & & & & \\
\hline \multirow{4}{*}{$\begin{array}{c}\mathrm{C} \\
\text { PENDAPATAN? }\end{array}$} & 3.311136 & 0.089299 & 37.07916 & 0.0000 \\
\hline & 0.050648 & 0.014399 & 3.517485 & 0.0048 \\
\hline & & & & \\
\hline & Effects $\mathrm{Sp}$ & pecification & & \\
\hline \multicolumn{4}{|c|}{ Cross-section fixed (dummy variables) } & \\
\hline & & & & \\
\hline R-squared & 0.996237 & \multicolumn{2}{|c|}{ Mean dependent var } & 3.613333 \\
\hline Adjusted R-squared & 0.995211 & \multicolumn{2}{|c|}{ S.D. dependent var } & 1.363224 \\
\hline S.E. of regression & 0.094336 & \multicolumn{2}{|c|}{ Akaike info criterion } & -1.660730 \\
\hline Sum squared resid & 0.097892 & \multicolumn{2}{|c|}{ Schwarz criterion } & -1.471917 \\
\hline Log likelihood & 16.45548 & \multicolumn{2}{|c|}{ Hannan-Quinn criter. } & -1.662742 \\
\hline F-statistic & 970.8450 & \multicolumn{2}{|c|}{ Durbin-Watson stat } & 1.891874 \\
\hline Prob(F-statistic) & 0.000000 & & & \\
\hline & & & & \\
\hline
\end{tabular}


Berdasarkan Tabel 3.6, diketahui nilai probabilitas pada baris Cross-section random adalah 0,7176. Karena nilai probabilitas lebih besar dibandingkan 0,05, maka hipotesis nol diterima, dan hipotesis alternatif ditolak. Hal ini berarti model REM yang akan digunakan.

\section{Referensi}

1. Agung, I.G.N. 2009. Time Series Data Analysis Using EViews. John Wiley \& Sons.

2. Baltagi, B.H. 2011. Econometrics, $5^{\text {th }}$ Edition, Springer.

3. Gujarati, D.N. 2003. Basic Econometrics, $4^{\text {th }}$ Edition. New York: McGraw-Hill.

4. Hill, R.C., W.E. Griffiths, dan G.C. Lim. 2008. Using EViews for Principles of Econometric, $3^{\text {rd }}$ Edition. John Wiley \& Sons, Inc.

5. Johnston, J. dan J. Dinardo. 1996. Econometric Methods, $4^{\text {th }}$ Edition. McGraw-Hill. 